Historic, Archive Document

Do not assume content reflects current scientific knowledge, policies, or practices. 




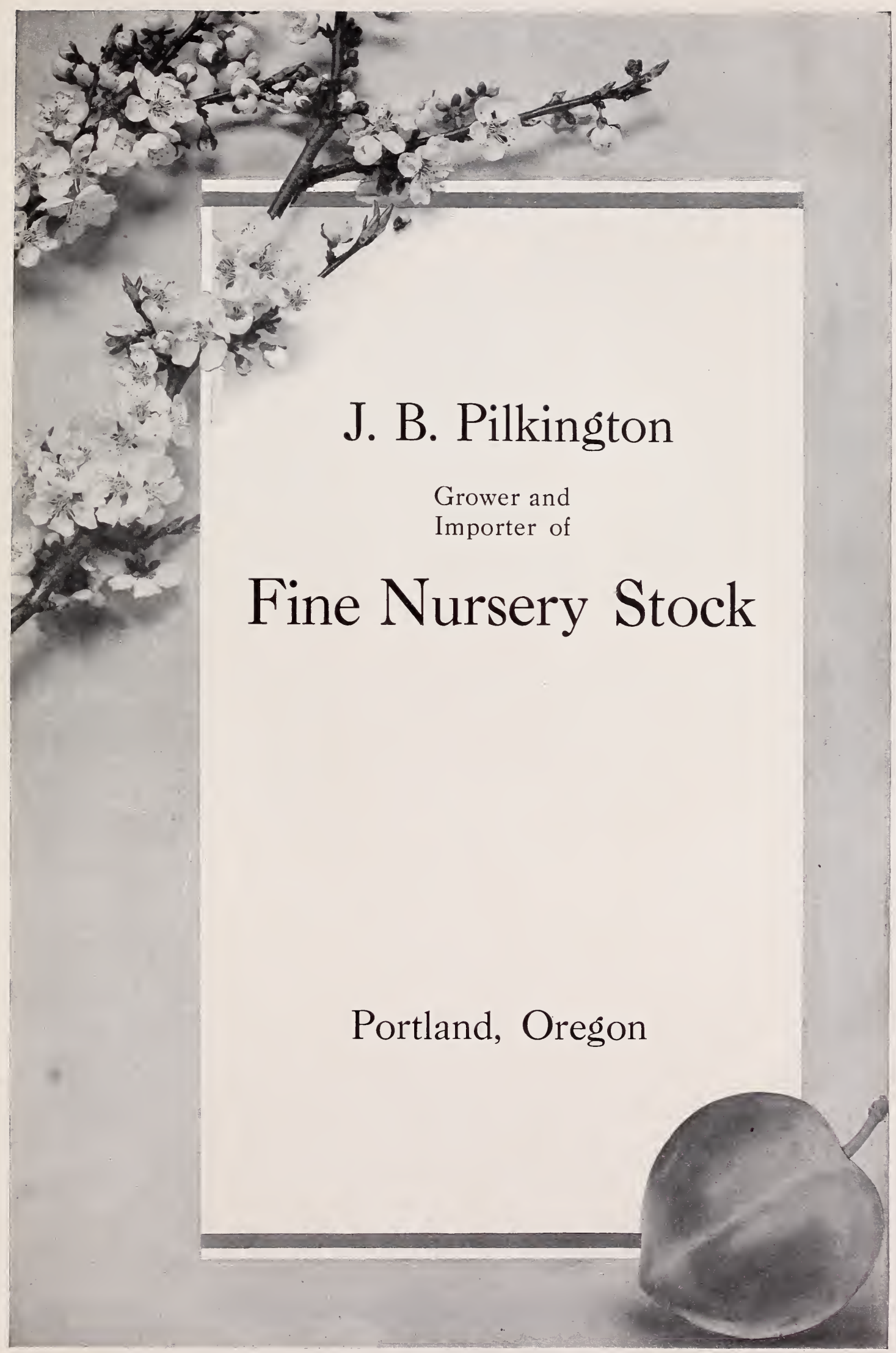




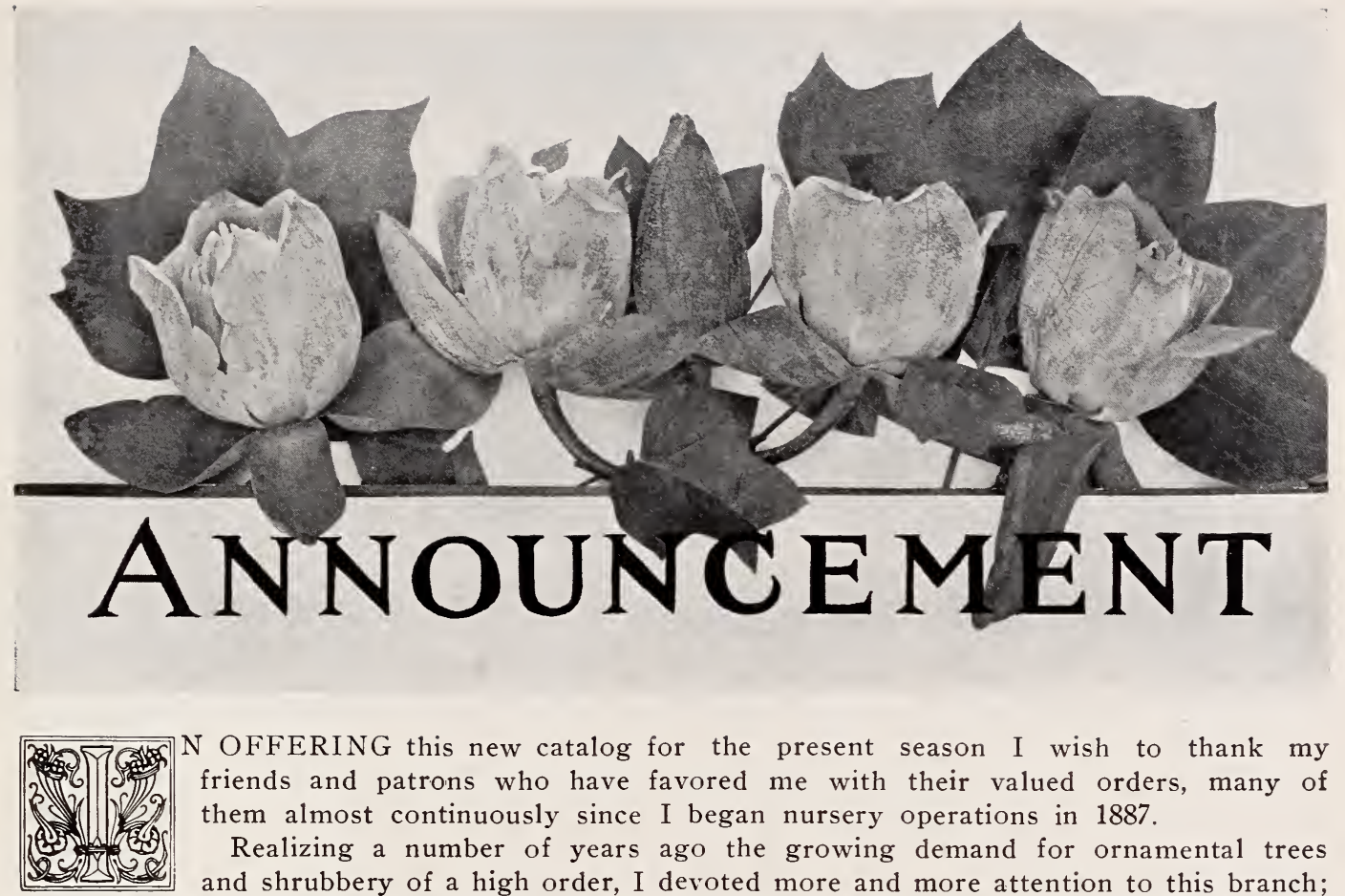

OFFERING this new catalog for the present season $I$ wish to thank my friends and patrons who have favored me with their valued orders, many of them almost continuously since I began nursery operations in 1887.

Realizing a number of years ago the growing demand for ornamental trees and shrubbery of a high order, I devoted more and more attention to this branch; already familiar with the ornamental trees and shrubbery in general use, I propagated these largely and also drew upon the best productions of the nursery centers of France, Holland, Belgium, Great Britain, Germany and Japan, and began trying plants that would be satisfactory; that would thrive under our climatic conditions and that would prove of conservative and lasting benefit, not fads to be purchased andplanted and then discarded a year or two later.

I have no greenhouses, or glass for propagating purposes; all stock is outside or field grown, hence hardy in this climate. Anything unable to stand our climatic conditions without nursing or protection, would perish in the nursery. I have tried out hundreds, perhaps thousands of plants, discarding or rejecting a large proportion which I deemed unworthy of further propagation, or not decided acquisitions of special merit. The result is a stock of high grade ornamental trees and shrubbery, modern and up-to-date, entirely suitable to the climatic conditions of the Pacific Northwest. One great inducement that I can offer my customers, old and new, is that my stock and list of varieties, the result of my 20 years' experience, work and study, is more modern, more varied in character and scope, and better grown, than any in the Western part of the United States. Eastern or outside nurseries, not familiar with our special needs and conditions; dealers and itinerant salesmen, often unreliable or working simply for their commission, cannot give the guarantee of adaptability, fitness and reliability of their stock that my products carry.

The growing of fruit trees is an important part of my business, and I grow and offer a full line of commercial orchard fruit and nut trees, berry plants, etc., and would be pleased to make prices on any list of wants in this line.

My plantings have been greatly increased, and I am in position to supply large quantities of standard sizes and varieties of fruit and ornamental nursery stock. I carry many varieties, both fruit and ornamental, that are not mentioned in this catalog; and if any customer fails to find what he desires, please inquire for it.

The office, packing and sales department are in Portland, foot of Yamhill Street; where during planting season a general assortment of Roses, Shrubbery and Vines, Shade and Fruit 
Trees, etc., are on hand for prompt delivery. The principal nursery for ornamental stock is on Columbia Boulevard, just east of Vancouver car line. (Take Vancouver car at Second and Washington Streets to Columbia Boulevard. Fare 5c.) I have here the finest general collection of high grade ornamentals in the Northwest. New varieties are constantly under trial, and during flowering season the display of Azaleas, Rhododendrons, Peonies, Iris and Roses attract hundreds of visitors, and at all times and seasons the grounds are interesting and attractive. Visitors are always welcome. The very best way to select stock is by personal visit to the nursery. We reserve, by tagging, all specimens selected, making delivery at proper time.

The product of this nursery is supplemented by extensive plantings near Durham, on the Oregon Electric; these additions being necessary to supply the increasing demand.

\section{Planting Season}

The proper time for transplanting nursery stock is often a disputed point, but the result of my many years' experience in planting all varieties of stock has been, generally speaking, that it is proper to transplant at any time from the falling of the leaves of deciduous trees in the autumn until buds begin to start in the spring. During severe weather in winter it is not advisable to handle stock; but our winters generally permit planting of stock right through the winter from November to March. Early fall planting is preferable as a rule; as roots form all winter and stock is ready to grow as soon as warm weather begins.

Is is advisable to order early as better selection and more complete assortment can generally be had. Orders placed early are usually planted early.

The nursery is examined by the County Inspector of Horticulture, and a copy of certificate showing freedom from scale or other injurious insects, or fungus diseases, is supplied with all shipments.

\section{Conditions}

PRICES AND DELIVERY.--Prices quoted herein are approximate, but will not necessarily prevail where personal selection of specimen plants is made at the nursery. Where prices quoted vary for a given article, customers are requested to state amount they desire to pay, and plants of corresponding size and grade will be selected. Mail orders receive personal attention, and it is my practice and intention to give good value to all purchasers.

No charge for delivery in city of Portland or to transportation lines; stock to be shipped is carefully packed in boxes or bales charged at cost, unless otherwise specified. Responsibility ceases with delivery to transportation company.

TERMS OF PAYMENT.-Net cash. Unknown correspondents should send cash with order, or usual commercial references.

GUARANTEE.-The living of trees is largely dependent upon conditions of weather and after-care beyond the nurseryman's control; therefore, I do not guarantee trees to live after leaving the nursery in good condition.

Without boasting infallibility, I warrant stock true to name and will replace any that may prove otherwise, or to refund the original purchase price, but will not be responsible for more than price paid for trees, and all sales are made with this understanding.

Particular attention is given to furnishing large lists and large quantities at lowest wholesale prices.

Planters desiring varieties and sizes other than quoted, and commercial orchard planters, are requested to send list of wants for special prices.

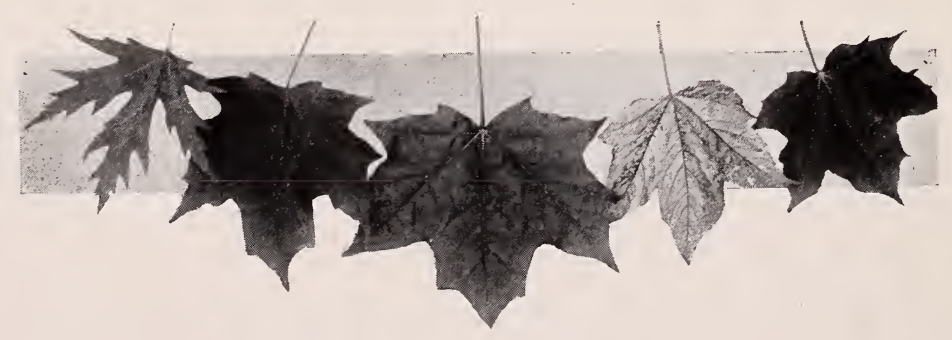




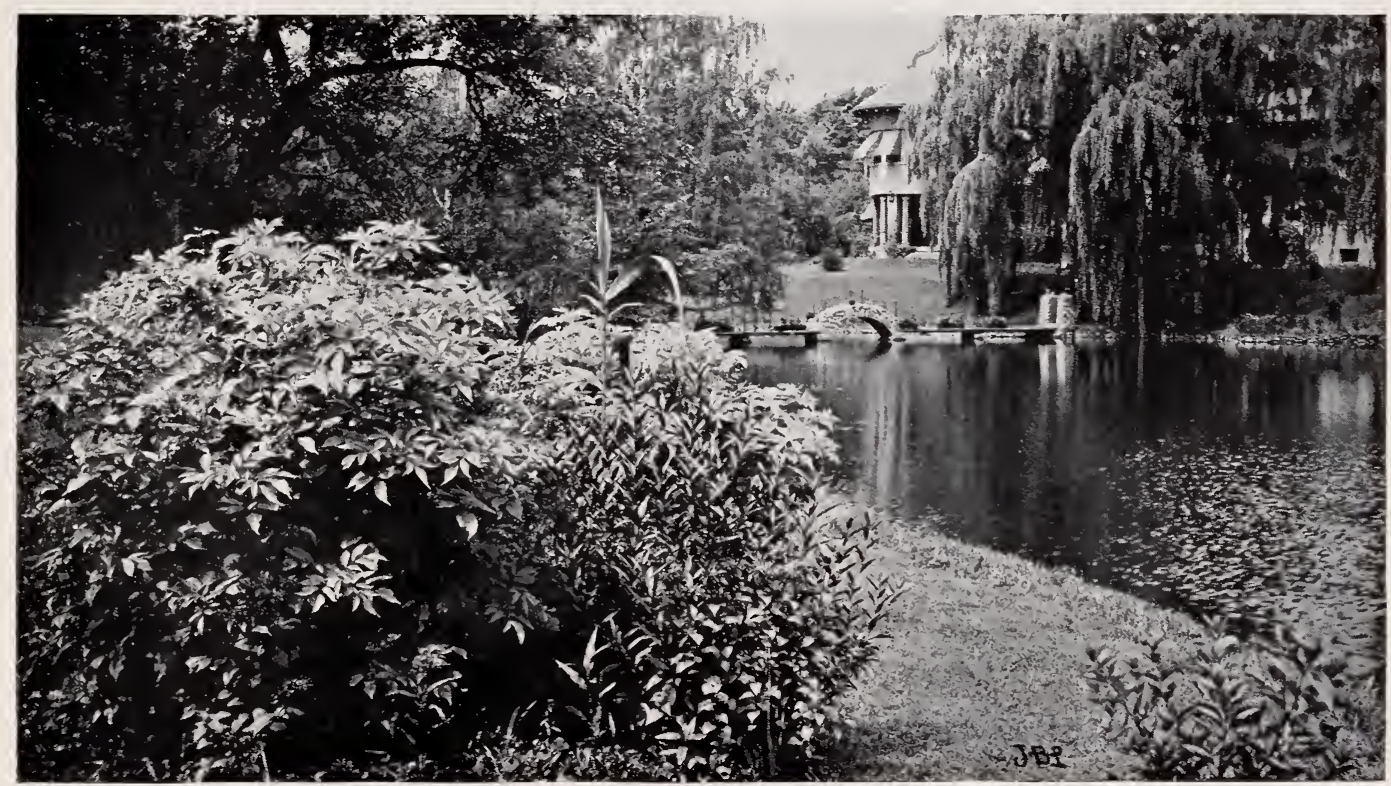

\section{Landscape Gardening}

\section{New Department}

Calls upon me for planting plans, general landscaping designs and expert advice during the last few years have grown to such extent that a new department, competent and fitted to undertake this work in proper and satisfactory manner, had to be organized.

The problem has been a serious one, the field is relatively new; trained and competent Landscape Architects-college trained engineers up in theory and who also have had some years actual field experience, and especially Western field practice, are scare and command comparatively high salaries. I have been fortunate, however, in securing the services of a Landscape Architect of high standing, a graduate of one of the best American Colleges of Landscape Engineering, who has also had a number of years of active practice designing and laying out grounds of all descriptions, large and small, and who for some years also taught landscape gardening in one of the best Western Agricultural Colleges.

Landscape engineering is a fine art and is classed with painting, sculpture and architecture. That is a fine art which attempts to create organized beauty; to unite several dissimilar parts into one completed, harmonious effect. Tersely speaking, landscape gardening is making pictures with plants. Ordinary gardening is the use of plants without reference to the picture.

The practice of landscape engineering, or landscape gardening, depends upon three very necessary things: A sense of the artistic, familiarity with plants, and an intimate knowledge of various crafts, such as surveying, mapping, constructive work of grading, draining, road-making and characters of soils, use of fertilizers, cultivation, etc.

The proper way to look at the home grounds is that they form a picture, with the house as the dominating feature, with the trees, shrubbery and flowers as vital parts of the composition; or as the frame in which the house, as a picture, is set.

It too often happens that a man will spend many thousands of dollars in building a home, but will leave the adornment of the grounds surrounding it to chance, planting trees and shrubbery without regard to their character, their correct placing, or to the conditions of soil and climate they will have to meet. 
Of late years there has been a wonderful movement towards a more systematic and conșistent planting of the home grounds. The knowledge of the landscape gardener is being sought more and more to the end that when a house is built its surroundings shall look as if they belonged to it - that the home and grounds shall form one harmonious whole.

The services of the landscape gardener are necessary in such cases, for he must understand not only the character and habit of the plants he deals with, but their adaptation to various soils and locations. He must be an architect and engineer that he may understand how to meet topographical and other conditions, and he must be an artist that he may be able to make the picture he has in mind with the means at his command.

Another important point in enlisting the services of the landscape engineer is the great increase in value which accrues to the home grounds by reason of his work. No other investment in connection with the home will yield as great returns. It has happened many times that an expenditure of a few hundred dollars in the outdoor embellishment of the home grounds has resulted in many thousands of increased value to the property.

All these factors should tend towards making our new Landscape Department an important feature of my business. Portland and all the other cities of the Pacific Northwest are growing rapidly and hundreds of handsome residences are being erected by people of taste and refinement who will gladly avail themselves of our services. Many of the older home-grounds can be likewise benefited by this department, which is prepared to draw plans for planting, design general effects, furnish estimates and if desired, supervise and even plant the proper things to create the landscape picture.

We will be very glad to confer with cities and towns that desire park plans, or designs for making the "City Beautiful," and with associations or individuals contemplating laying out of cemeteries, public and private grounds or parks, schools grounds, amusement parks and play grounds, railway stations, etc.

Upon receipt of advices from those contemplating the laying out or improvement of their home-grounds or any work in which the service of a landscape architect or gardener is needed I shall be glad to send my representative, well equipped to supply the necessary advice and suggestions, charging for same at reasonable rates.

Questions as to selection of planting material, and general advice upon matters horticultural will be cheerfully answered at the downtown office at any time.

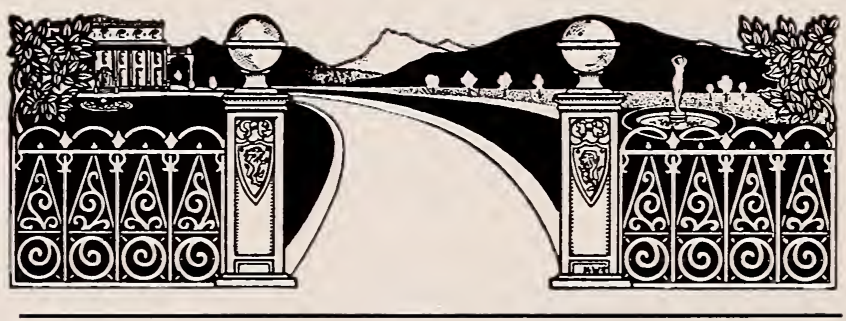




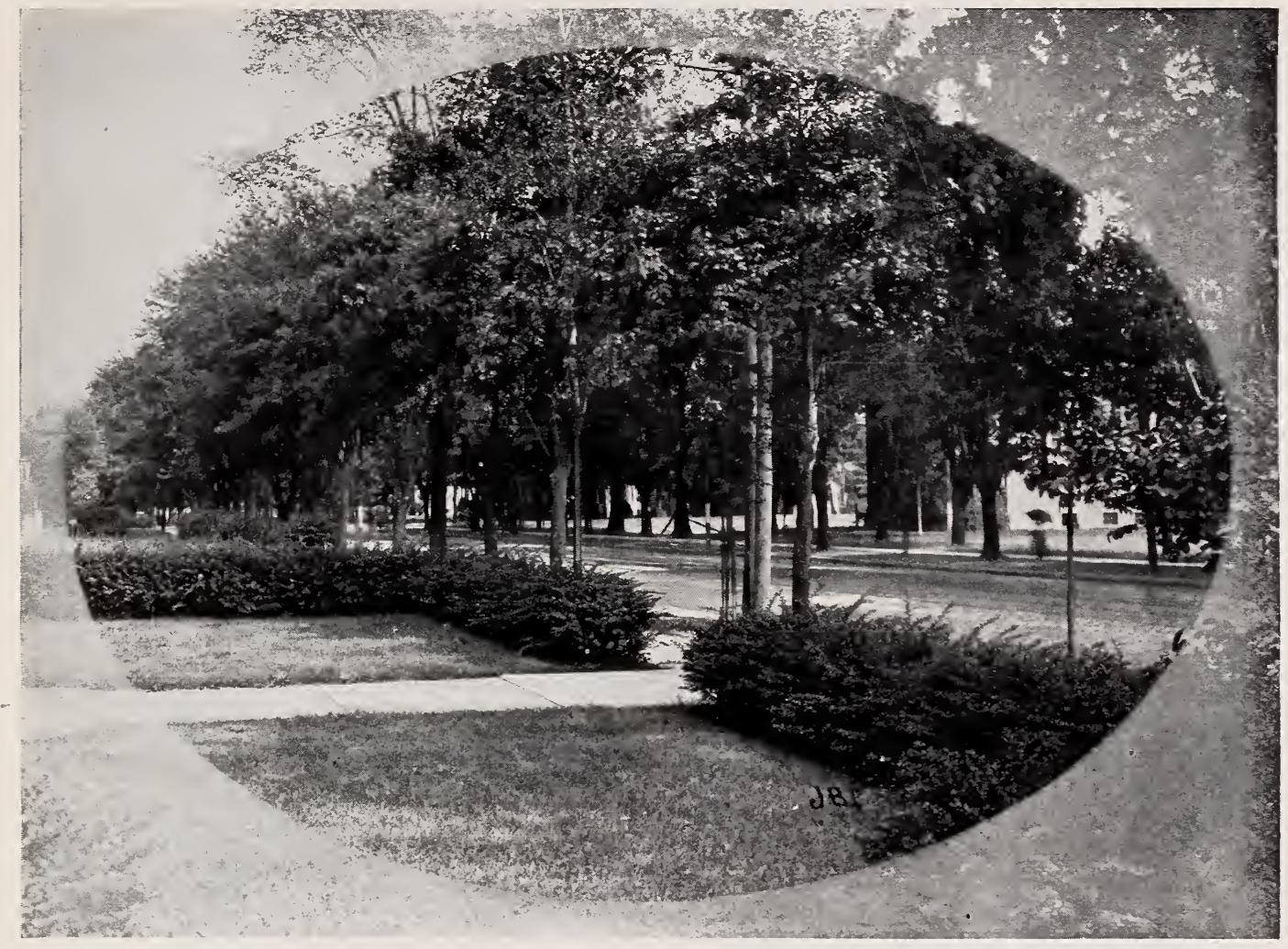

\section{Deciduous and Ornamental Trees}

The following list of Deciduous, Ornamental, and Shade Trees embraces a selection for all planting purposes. For the avenue and street Birch, Catalpa, Elm, Hawthorn, Horse Chestnut, Linden, Locust, Maple, Mountain Ash, Tulip, and Walnut are most generally used; while for the garden and landscape this varied list covers every characteristic in outline and habit, color of foliage, and floral diversity.

\section{Ash. Fraxinus}

American White (Fraxinus Americana). A rapid growing, medium sized tree, fine proportions and long lived, suitable for streets or lawns. 4 to 6 feet, 50 cts.; 6 to 8 feet, 75 cts.; 8 to 10 feet, $\$ 1.00$; large size, specimen trees, $\$ 1.50$.

See Mountain Ash.

\section{Beech. Fagus}

European (Fagus sylvatica). A large and beautiful tree, with ovate or elliptic, dark green and glossy leaves. $50 \mathrm{cts}$. to $\$ 1.50$.

Cut-leaf Beech (Fagus sylvatica asplenifolia). Leaves deeply divided, cut almost into the midrib into numerous narrow segments. A graceful variety, forming a dense low tree. $\$ 1.00$ to $\$ 2.00$.

Weeping Beech (Fagus sylvatica pendula). Branches long and pendulous. Foliage deep green. Very picturesque. Grafted on 6-ft. stems. $\$ 2.00$.

Copper, or Purple-leaf Beech (Fagus sylvatica purpurea). A strong and vigorous tree of elegant habit, with most beautiful foliage, changing from dark purple to red and then to a purplish green. A graceful and handsome specimen tree. $\$ 1.50$ to $\$ 2.50$, and specimens at $\$ 3.00$ to $\$ 5.00$.

Weeping Copper Beech (Fagus sylvatica purpurea pendula). A weeping form of above, likewise striking and distinct. Specimens, $\$ 2.00$ to $\$ 3.00$.

\section{Birch. Betula}

European White Birch (Betula alba). Rapid grower. Bark silvery white, branches spray-like. Very effective. 75 cts. to $\$ 1.50$.

Cut-leaf Weeping Birch (Betula alba laciniata pendula). Bark and branches silvery white; graceful, slender, drooping branches and finely cut leaves. $\$ 1.50$ to $\$ 2.50$.

Purple-leaved Birch (Betula purpurea). Lightcolored bark. Foliage beautiful shade of purple when young, changing to green with the advance of the season. Very distinct. $\$ 1.00$ to $\$ 1.50$.

\section{Catalpa. Indian Bean}

Rather rapid growing, large leaved trees, flowering in July. Hardy and should be more extensively planted.

Chinese (Catalpa Bungei). A dwarf variety -native of China-branching to the ground 
without stem. When top grafted at about six feet from ground on strong stems of other Catalpas, it forms a fine head, covered with a dense mass of large heartshaped, light green leaves. Very hardy and effective. Much used in formal and semiformal gardens, as it has the outlines of the standard Bay Tree. Bears panicles of white flowers, but is shy bloomer. Fine specimens, $\$ 1.50$ to $\$ 3.00$, according to size.

Japanese (Catalpa Kæmpferi). Rapid grower, with deep green, glossy foliage. Flowers fragrant, cream-colored and spotted yellow and purple. $\$ 1.00$.

Catalpa (C. Syringæfolia). A showy, rapid growing, spreading, irregular tree, with pyramidal clusters a foot long, of white and purple fragrant flowers. Blooms latter part of July, when few trees are in blossom, and, therefore, very desirable. 8 feet, $\$ 1.00$.

Western Catalpa (C. speciosa). A mediumsized tree of great hardiness. Foliage is large, oval; light green in color. Flowers white with yellow spots, borne in large panicles in July, when few trees are in bloom. Forms a round, compact head, not too high -which makes it esvecially suitable for street curb planting. While it prefers a moist soil it will thrive anywhere. This tree is planted extensively in the Middle West for fence posts and timber purposes. A handsome and valuable tree worthy of general planting for all purposes. 4 to 6

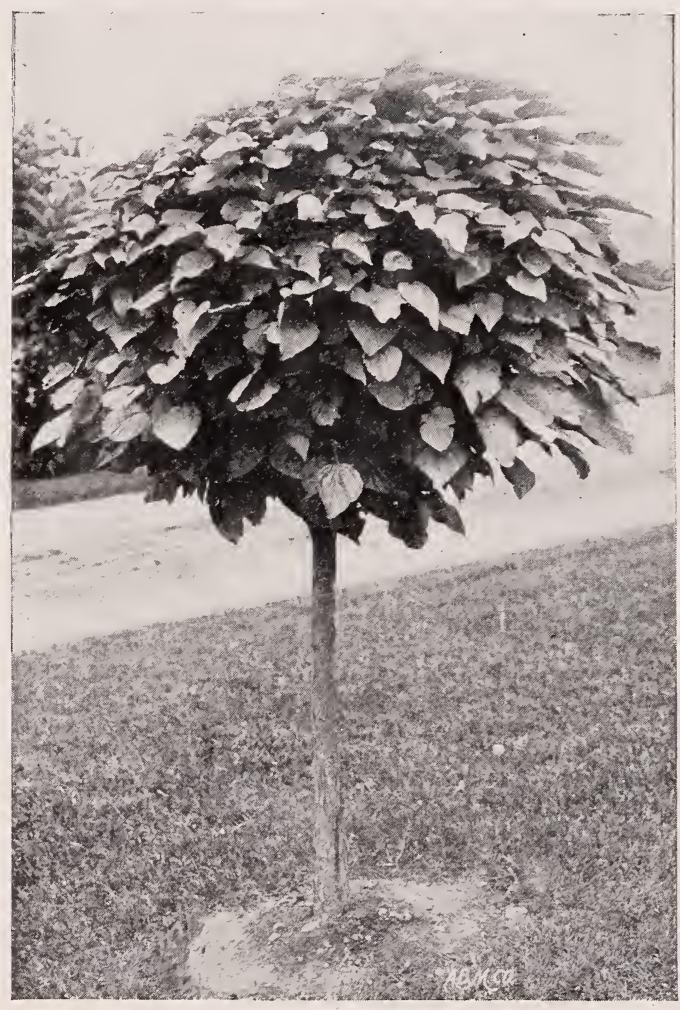

CATALPA BUNGEI.

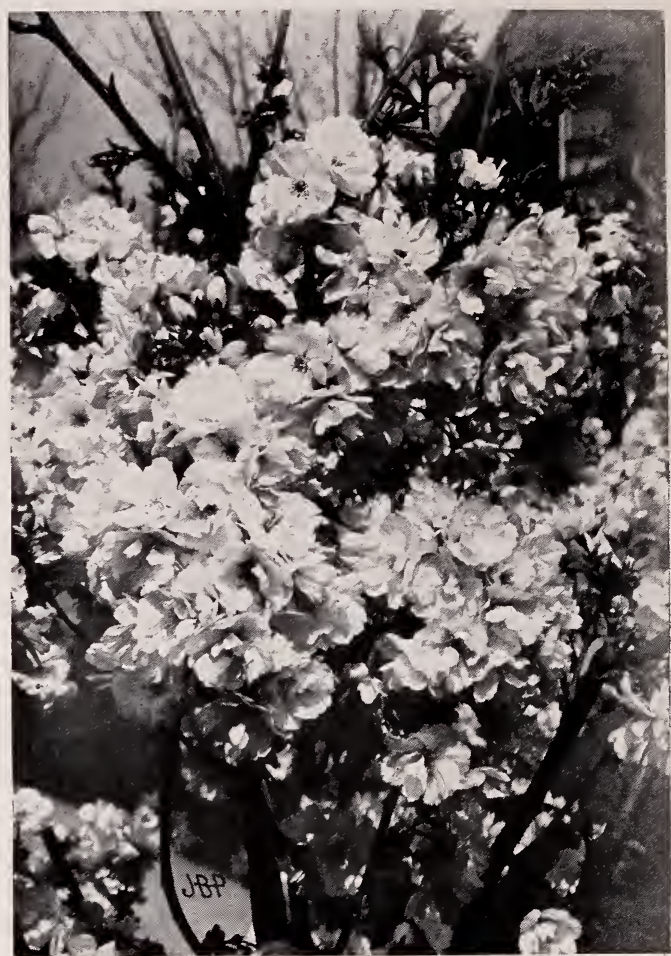

DOUBLE FLOWERING CHERRY

feet, 50 cts.; 6 to 8 feet, 75 cts.; 8 to 10 feet, $\$ 1.00$; larger sized specimen trees, $\$ 1.50$.

\section{Flowering Cherry. Cerasus}

Japanese Cherry. Japan is famous for its flowering Cherries. I have a fine collection of double and single-flowering sorts in stock, and several Weeping varieties. Japanese names are impossible. Can supply by color and description. $\$ 1.50$ to $\$ 2.50$. Specimens, $\$ 3.00$ to $\$ 5.00$ each.

Japanese Double Flowering Pink Cherry (Cerasus Japonica rosea flora plena). Upright form of the double rose flowering Cherry. $\$ 1.00$ to $\$ 1.50$.

European Double Flowering Cherry (Cerasus avium alba flora plena). Covered in May with very double blossoms resembling a rose. A fine, round-headed dwarf tree, valuable in any situation. $\$ 1.00$ to $\$ 1.50$.

Chestnut. See Nut Trees and Horse Chestnuts.

\section{Flowering Crab Apple. Malus}

Bechtel's Double Flowering Crab (Malus augustifolia). Bears masses of double, roselike flowers, of a delicate pink color and most delightful fragrance. Blooms when quite young. 3 to 4 feet, $\$ 1.00$.

Flowering Crab (Malus floribunda). Single flowers, buds carmine and white when open. Full of small, red fruit in autumn. \$1.00.

Parkman's Flowering Crab (Malus Halleana). A form with beautiful semi-double rose-colored flowers. $\$ 1.00$. 


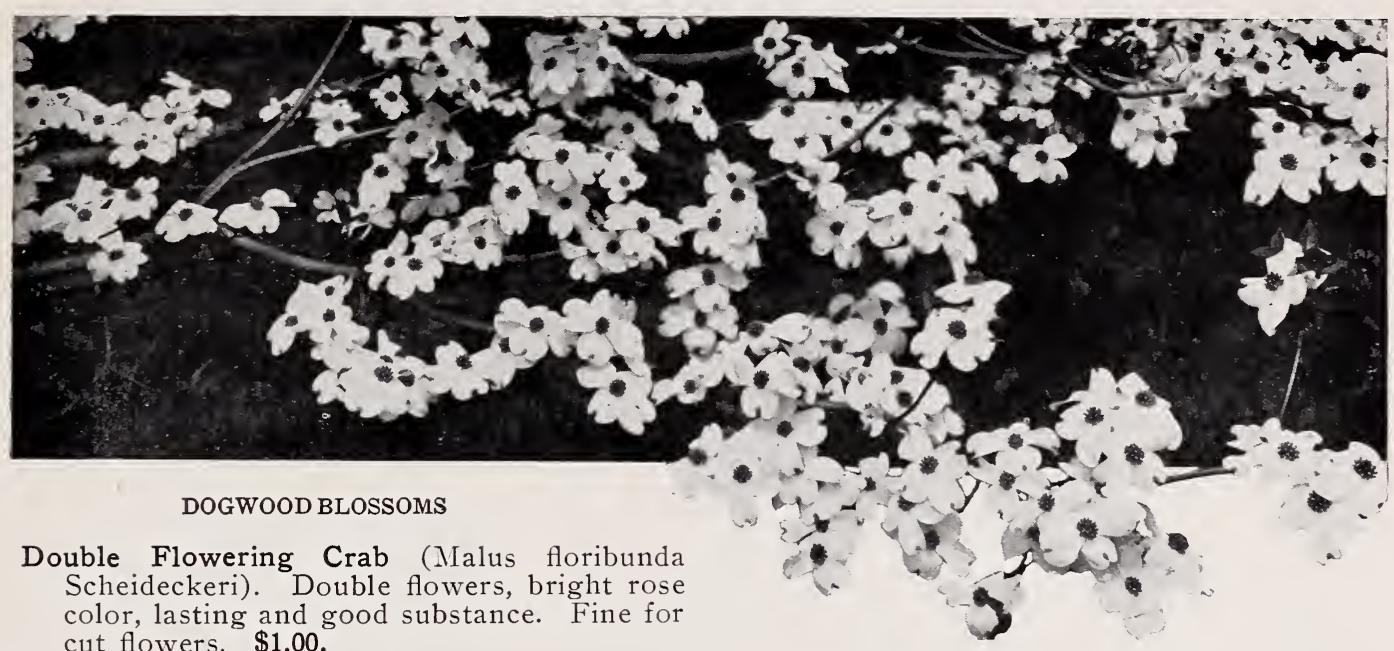

\section{Dogwood. Cornus}

Oregon Dogwood (Cornus Nuttalli). This is the Dogwood of our Pacific Northwest woods-the handsomest of all our Deciduous Trees. Its immense white flowers open in April, and it often flowers again in September, when the white blossoms, red fruits and gorgeous foliage intermingle, producing an effect beyond description. The grayish splotchy bark makes it an ornament to the winter landscape. Should be in every collection. 75 cts. to $\$ 2.50$.

Red-flowering Dogwood (Cornus florida flora rubra). Very handsome in flower and foliage. The leaves turn a magnificent crimson in autumn. Flowers of a bright rosyred color, shading to a lighter hue toward edge of petals. A choice, small ornamental tree. $\$ 1.50$ to $\$ 2.00$.

White-flowering Dogwood (Cornus florida). Very beautiful and ornamental. Eastern native tree, bearing white flowers in spring before the leaves appear. $75 \mathrm{cts}$. to $\$ 1.00$.

Small Flowering Dogwood. See Shrubs.

\section{Elm. Ulmus (See page 5.)}

One of the best known shade trees, closely associated with American historical events, as well as with home or childhood recollections of the greater part of us. It thrives equally well everywhere in cool, shady parks or in crowded and smoky city streets. The magnificent Elms in this city on Sixth Street, from Yamhill south, and in other locations, prove its suitability for city planting in the Northwest. 4 to $6 \mathrm{ft}$. trees, $50 \mathrm{cts}$; 6 to $8 \mathrm{ft}$. trees, 75 cts.; 8 to $10 \mathrm{ft}$. trees, $\$ 1.00 ; 10$ to $12 \mathrm{ft}$. trees, $\$ 1.50$; a few fine specimens, 15 feet up, at $\$ 2.00$ to $\$ 3.50$ each.

American White Elm (Ulmus Americana). Lofty and spreading, with drooping branches.

Cork Elm (Ulmus alata). A medium sized tree, with corky winged branches. Leares ovate, coarsely serrate, dark green at maturity, turning yellow in autumn. An at-

tractive tree with a narrow, round-topped crown.

English Elm (Ulmus campestris). More erect in growth than the American Elm, compact, and with smaller foliage and twiggy branches and trunk. A hardy, valuable tree.

Camperdown Weeping Elm (U1mus campestris Camperdowni pendula). A remarkably picturesque weeping tree which extends its branches horizontally until it forms a complete arbor, its outer branches touching the ground. There is no other weeping tree quite like it. It does not grow over 15 feet high, while the spread of its branching head will cover 40 feet or more. Strong heads, $\$ 1.50$ to $\$ 2.50$.

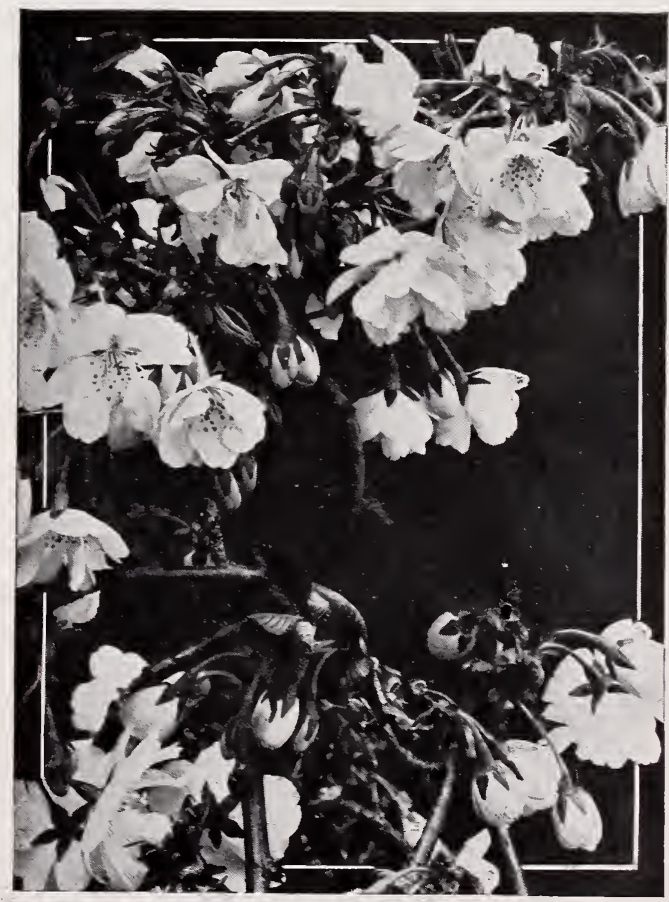

FLOWERING CRAB. 


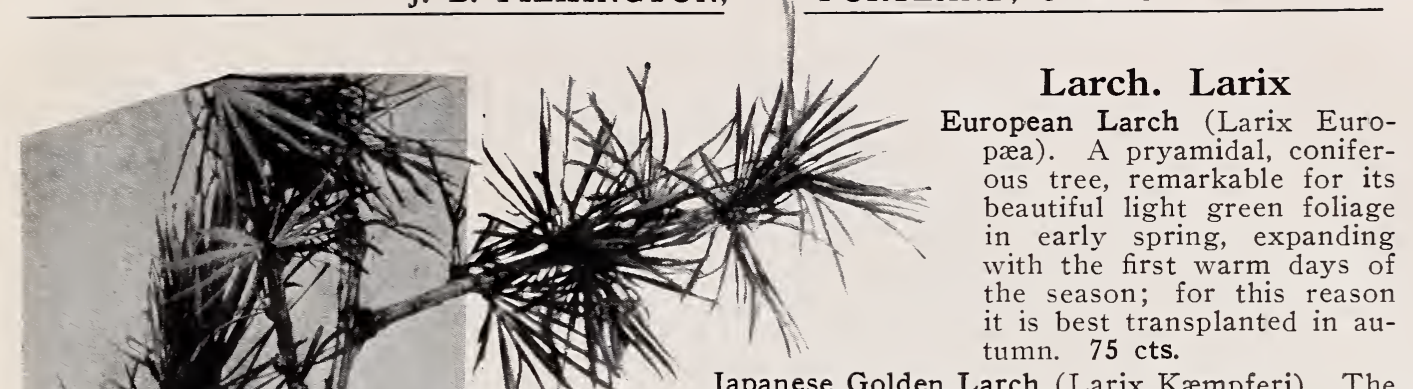

Japanese Golden Larch (Larix Kæmpferi). The foliage, when young, is light green, changing to a fine golden yellow in autumn. 75 cts.

\section{Linden or Lime. Tilia}

Silver-leaved Linden (Tilia argentea). A large-sized tree, forming a compact, round head. It is of rapid growth and useful for street and avenue planting, as well as for ornamental purposes. The leaves are green above and silver beneath, and hold their color late in the fall. $\$ 1.00$ to $\$ 1.50$.

European Linden (Tilia platyphyllos). A large and stately tree, with a handsome, pyramidal crown, or, in age, round-topped and massive. Leaves heart-shaped, relatively large; dark green, turning yellow in autumn. Flowers large, yellowish-white, fragrant. The largest European Lime tree. $75 \mathrm{cts}$. to $\$ 2.00$.

\section{Magnolia}

Chinese White, or Yulan (Magnolia conspicua). Makes a low, round tree, covered in April with masses of large, snow-white, lily-like flowers. A beautiful object. Flowers before the leaves appear. One of the best. $\$ 1.00$ to $\$ 2.50$.

Cucumber Tree (Magnolia acuminata). One of the largest Magnolias; of a very rapid growth, forming a pyramidal tree of much beauty; flowers yellowish-white, expanding in latter part of May. $\$ 1.00$.

Pink Magnolia (Magnolia Soulangeana). Perhaps the most popular of all Magnolias, being of vigorous growth, and blooming profusely even when quite small. The flowers are large, pink on the outside of petals and white inside. It can be grown as a small tree or as a large shrub-as a single specimen or in masses. $\$ 1.00$ to $\$ 2.00$. Specimens with bloom buds, $\$ 3.00$ to $\$ 5.00$.

Purple Magnolia (Magnolia obovata). Holds its large purple flowers persistently, and is a most useful variety. $\$ 1.00$ to $\$ 2.00$.

Southern Magnolia (Magnolia grandiflora). See Broad leaved Evergreens.

Starry Magnolia (Magnolia stellata, or Halleana). A charming dwarf tree. Flowers double, pure white, or with a rosy flush: petals long and narrow. The blossoms greatly resemble our Pond Lily in appearance. The fragrance is delicate. Earliest blooming of all the Magnolias, and the most abundant bloomer. $\$ 1.50$ to $\$ 2.50$.

Umbrella Tree (Magnolia tripetala). Of medium size, with immense leaves, and white flowers nearly 6 inches across. Flowers in June. Entirely hardy and vigorous. $\$ 1.00$.

White Magnolia (Magnolia alba superba). A fine form of the parent, Magnolia conspicua. Flowers white. Specimens with bloom buds, $\$ 2.50$ to $\$ 5.00$.

\section{Maidenhair Tree or Ginkgo. Salisburia}

Ginkgo Biloba (Salisburia adiantifolia). Different from other trees. Its foliage spray resembles the Maidenhair Fern it is named for; of large columnar shape, it is beautiful and unusual. Still rare. A broad-leaved deciduous conifer-native of China and of great antiquity, altho it is the only representative of its genus. Fruit plum like, 


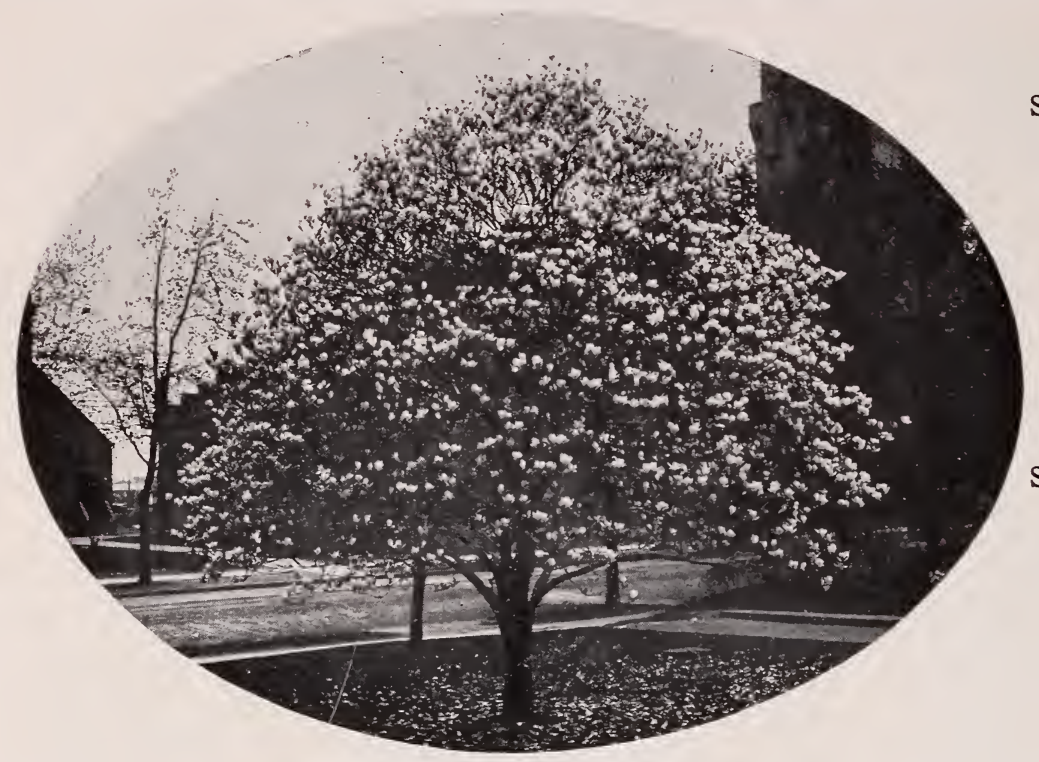

MAGNOLIA SOULANGEANA.

about one inch in diameter. Has proven very successful in Washington, D. C., as a street and avenue tree. It is an admirable lawn specimen tree for those who do not like the Poplars, as it adds to architectural values in same way. Fine trees, 8 to $10 \mathrm{ft}$, $\$ 1.00$; larger sizes, $\$ 1.50$ up.

\section{Maples. Acer}

The Maples are unquestionably among the best and most satisfactory shade trees we have. They afford great variety-range of size, form, density, foliage and color, making it possible, by judicious selection, to use them in almost any place.

Ash-leaved Maple (Acer Negundo). Ashleaved Maple; also called Box Elder. Fine rapid-growing tree; spreading habit. Desirable for shade. 8 to $10 \mathrm{ft} ., \$ 1.00 ; 10$ to 12 $\mathrm{ft}$., $\$ 1.25$.

Ash-leaved Silver Maple (Acer. Negundo argenteum). A white-leaved variety of the above, often called Silver Maple; in reality, is the White Variegated Ash-leaved Maple, or Box Elder. There are many beautiful specimens in the city of Portland, those at entrance of Good Samaritan Hospital being noteworthy. A striking tree and most satisfactory for massing effects or specimen planting. 4 to $6 \mathrm{ft}$., $\$ 1.00$; 6 to $8 \mathrm{ft}$., $\$ 1.50$.

Norway Maple (Acer platanoides). One of the most valuable ornamental trees for street and lawn. A large, handsome tree with spreading head; broad, dark green foliage. Very compact growth; free from insects, and makes an excellent shade tree. 75 cts. to $\$ 2.00$.

Purple Norway Maple (Acer platanoides Reitenbachi.) Reitenbach's Norway Maple. A magnificent and beautiful tree, remarkable for the changing colors of its leaves. Foliage beautiful green in early spring, changing to purple toward midsummer. Retains its color throughout the season. 5 to $7 \mathrm{ft}$., $\$ 1.00$.

Silver Maple (Acer dasycarpum). Large sized tree, with widespreading branches a nd pendulous branchlets; rapid grower. Foliage bright green above and silvery white underneath. Very suitable for street planting. 8 to $10 \mathrm{ft} ., \$ 1$; 10 to 12 ft., \$1.25.

Sycamore Maple (Acer $\mathrm{P}$ s e u d o - p l a t anus). Very quickgrowing $\mathrm{tree}$, of handsome spreading form. Bold, dark green foliage. An excellent lawn and shade tree. A 1 s o fine for seashore planting. 75 cts. to $\$ 2.00$.

W e ir's Cut-leaf Silver Maple (A c e r dasycarpum laciniatum Weirii). A weeping, graceful Silver Maple. Leaves cut-leaved, which gives it a feathery appearance. Branches pendulous, often sweeping to the ground. This tree lacks the density of head that usually characterizes the Maples. A great favorite, and of deserved popularity. There are some fine specimens bordering street curbs in Holladay's Addition, Portland. Fine, well shaped trees, 8 to $10 \mathrm{ft}$., $\$ 1.00 ; 12$ to $15 \mathrm{ft}$., $\$ 1.50$.

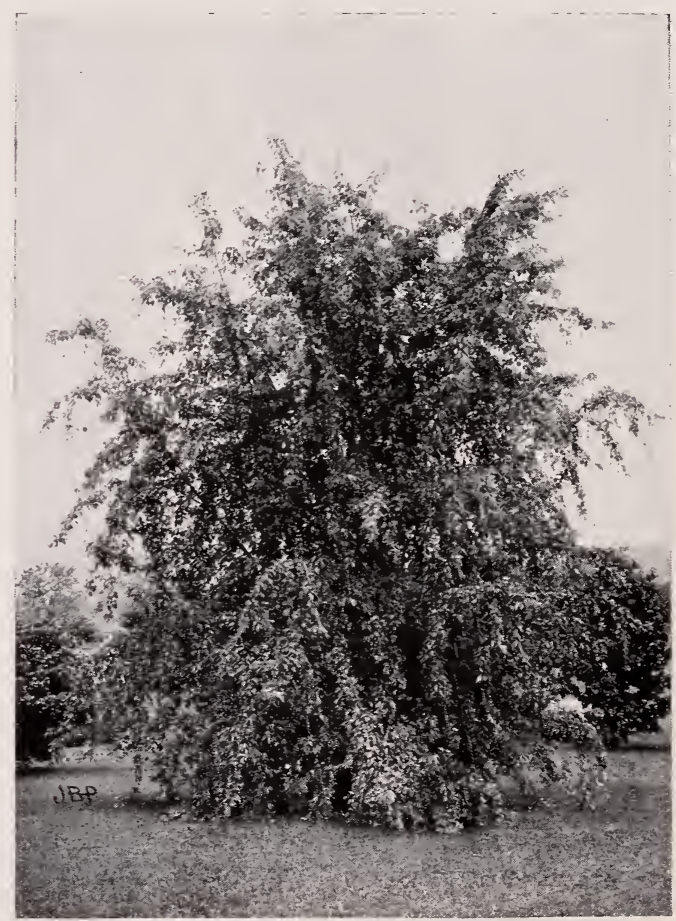

WIER'S CUT LEAF SILVER MAPLE. 


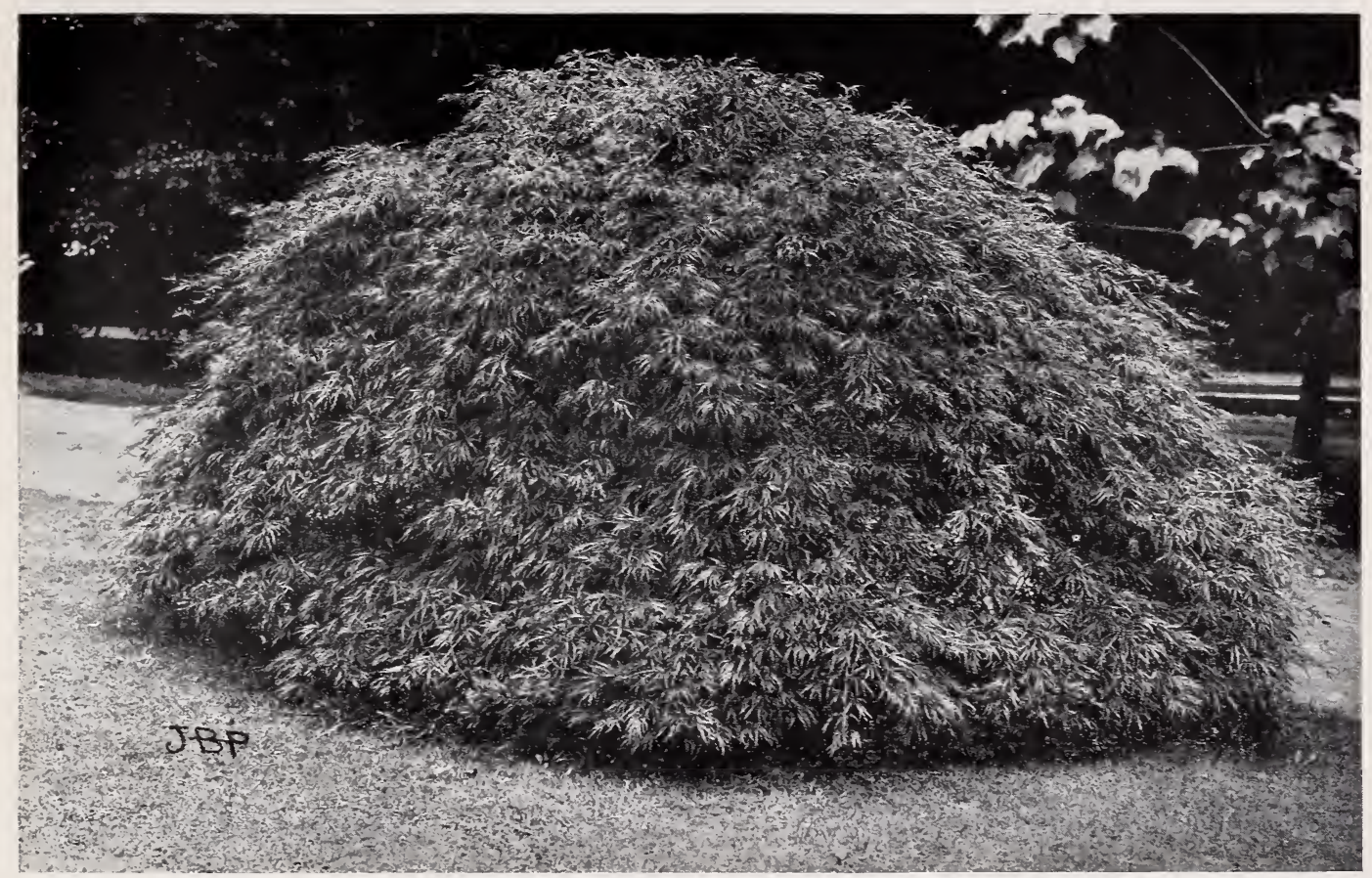

CUT-LEAF JAPAN MAPLE.

Specimen in Grounds of North Pacific Sanatorium, Portland

\section{Japanese Maples. Acer Japonicum}

These beautiful, small trees have been one of my specialties for many years. Though classed as trees, their dwarf habit makes them more effective when grouped, or massed in borders, and treated as hardy shrubs. For forming permanent beds of color and delicate foliage, they are unsurpassed. When grown in groups or borders, planted 3 to 5 feet apart, they give one of the most beautiful results in foliage effect possible in the use of hardy stock.

The varieties as described below have proven hardy and are easily grown. The crimson-red foliage of the Atropurpureum variety is particularly striking and beautiful, and wonderfully effective either in specimens or groups, and the varieties named have proven the most satisfactory among several dozen tried out during the past ten years. $11 / 2$ to $2 \mathrm{ft}$., $75^{*} \mathrm{cts}$.; 2 to $3 \mathrm{ft}$., $\$ 1.00$ to $\$ 1.50$; specimens, $\$ 3.00$ to $\$ 5.00$ each.

Broad-leaf Gold Japanese Maple (Acer aureum). A very beautiful variety, of slow, compact growth; leaves broad, of a bright golden color, often suffused with a shade of green.

Broad-leaf Red Jap. Maple (Acer atropurpureum). Dark red-leaved Japan Maple. Of compact growth; leaves of a beautiful dark purplish red or claret color. One of the most beautiful small trees or shrubs known.

Cut-leaf Red Jap, Maple (Acer atropurpureum dissectum.) Red cut-leaved Weeping Japan Maple. The foliage of this variety is a rich claret color, and as delicately cut as the finest fern. Dwarf and compact, of a distinct weeping habit. One of the most effective varieties.

Ribbon-leaf Dark Red (Acer scolopendifolium rubrum). Scalloped purple-leaved variety. Deeply cut, narrow leaves of a rich claret color. Very graceful.
Mountain Ash. Sorbus Acuparia

European Mountain Ash. Handsome, small tree, with pinnate foliage and bearing clusters of bright red berries in fall. $75 \mathrm{cts}$. to $\$ 2.00$.

\section{Mulberry. Morus}

New American Mulberry. Valuable especially for its fruit, which is large, black and very edible. Its fruit ripens from June until September. Leaves are larger than other varieties. $75 \mathrm{cts}$.

Tea's Weeping Mulberry (Morus alba pendu1a). A weeping form grafted on straight stems. The branches are long and slender, drooping to the ground. One of the most vigorous and hardy of weeping trees. $\$ 1.50$ to $\$ 3.00$ each.

\section{Oak. Quercus}

Scarlet (Quercus coccinea). There are no better Oaks than this variety. It forms a large tree of fine proportions, the large, leathery leaves turning to a fiery scarlet in autumn. A good specimen tree. $\$ 1.00$ to $\$ 1.50$. A few large specimens, $\$ 3.00$ to $\$ 5.00$. 


\section{Flowering Peach and Plum Prunus}

Double White-flowering Peach (Prunus Persica vulgaris alba plena). A double, whiteflowering form of the common Peach. Not only do the Flowering Peaches make beautiful garden objects, but they are very valuable as cut-flowers. 75 cts. Specimens, $\$ 1.50$ to $\$ 3.00$.

Double Pink-flowering Peach (Prunus Persica vulgaris rosea plena). A form of the Peach with beautiful double rose-colored flowers. A charming spring flowering tree. 75 cts. Large specimens, $\$ 1.50$ to $\$ 3.00$.

Purple-leaved Plum (Prunus Pissardi). Handsome form, with purple leaves and wine-red fruits; one of the best of the small purpleleaved trees, retaining its color until fall. Hardy wherever the common Plum will stand. 75 cts. Large specimens, $\$ 1.50$ to $\$ 2.50$.

\section{Poplar. Populus}

Carolina Poplar (Populus Carolinensis). A symmetrical and very rapid growing tree, making an upright or pyramidal head. The most popular and widely planted species. $50 \mathrm{cts}$. to $\$ 1.00$.

Lombardy Poplar (Populus fastigiata). The well-known pyramidal Italian variety; upright, and of wonderfully rapid growth. Fine for landscapes. $50 \mathrm{cts}$. to $\$ 1.00$.

\section{Red Bud. Cercis}

American Red Bud (Cercis Canadensis). Also called American Judas Tree. A choice, lowgrowing, round-shaped tree. Before the foliage appears, the stems are clothed with a profusion of reddish-purple flowers, quite unique in color and appearance. The leaves are heart-shaped, with a glossy surface, and the tree, in all aspects, is one of the very best. 50 cts.

Japanese (Cercis Japonica). A Japan variety. The flowers are larger than those of Canadensis, and the habit similar to that variety. 75 cts.

\section{Sassafras}

Sassafras (Sassafras officinalis). An aromatic tree, hardy and ornamental, attaining good size in rich soil. Prefers sunny location. Bright green leaves turning to orange and red in fall. Flowers yellow with dark blue fruit in autumn. The bark of the roots is prized as a mild aromatic stimulant. $75 \mathrm{cts}$. to $\$ 1.50$.

\section{Sweet Gum. Liquidambar}

Sweet Gum (Liquidambar styraciflua). One of the best of our native Eastern trees. Its star-shaped leaves, glossy and green in summer, take on in fall, the most intense shades of purple, orange and crimson, and for this autumn aspect alone it should be grown. Of stately growth, with corky bark. $\$ 1.00$ to $\$ 2.00$.

\section{Sycamore. Platanus}

Sycamore (Platanus orientalis). Oriental Plane Tree. One of the finest for streets or lawn, and valuable for general planting. Straight trunk, handsome clear foliage and symmetrical heads. $\$ 1.00$ to $\$ 1.50$.

American Sycamore (Platanus occidentalis). Buttonwood. A magnificent large tree with heart-shaped leaves. Fine for street planting as it is not subject to fungous diseases. $\$ 1.00$ to $\$ 1.50$.

\section{Tulip Tree. Liriodendron}

Tulip Poplar (Liriodendron tulipifera). A large and stately, rapid-growing tree, with a narrow pyramidal crown. Leaves four-lobed, bright green and lustrous, turning yellow in autumn. Flowers cup-shaped, resembling a tulip, greenish-yellow, blotched with orange. A handsome tree, and one that is deserving of the highest esteem of planters. 75 cts. to $\$ 1.50$.

\section{Varnish Tree. Koelreuteria}

Varnish Tree (Koelreuteria paniculata). An ornamental tree from China. Forms a flat, spreading head, has large pinnate leaves, and in July produces immense panicles of orange-yellow flowers. Desirable for its bloom and autumnal color. 75 cts.

\section{Walnuts}

See Nut Trees.

\section{Willow. Salix}

Weeping Willow (Salix Babylonica). A wellknown and particulary graceful tree; indispensable in all plantations. 50 cts.

Kilmarnock Weeping Willow (Salix caprea pendula). Perfect umbrella head and glossy foliage. Top grafted on stems 6 to 8 feet. $\$ 1.00$.

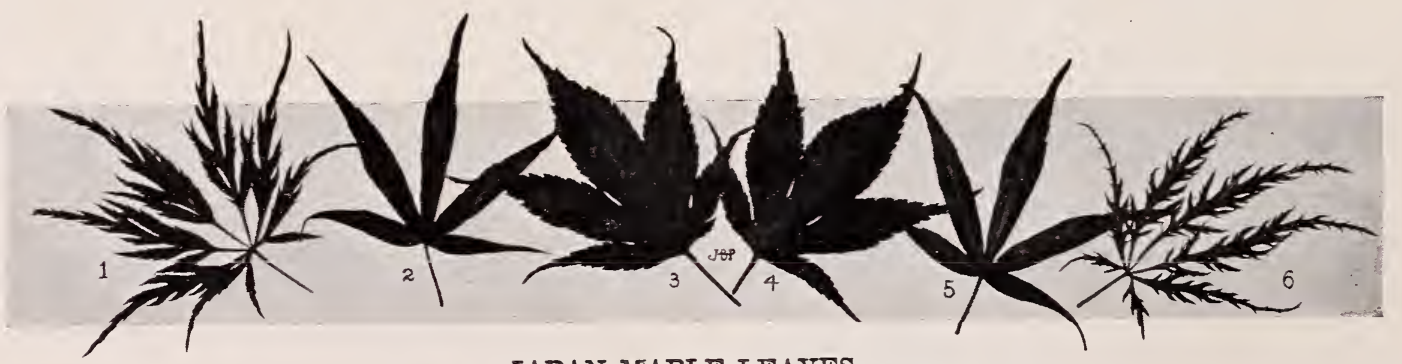

JAPAN MAPLE LEAVES.

Leaves 1 and 6 Acer atropurpureum dissectum.

Leaves 2 and 5 Acer scolopendifolium.

Leaves 3 and 4 Acer atropurpureum. 


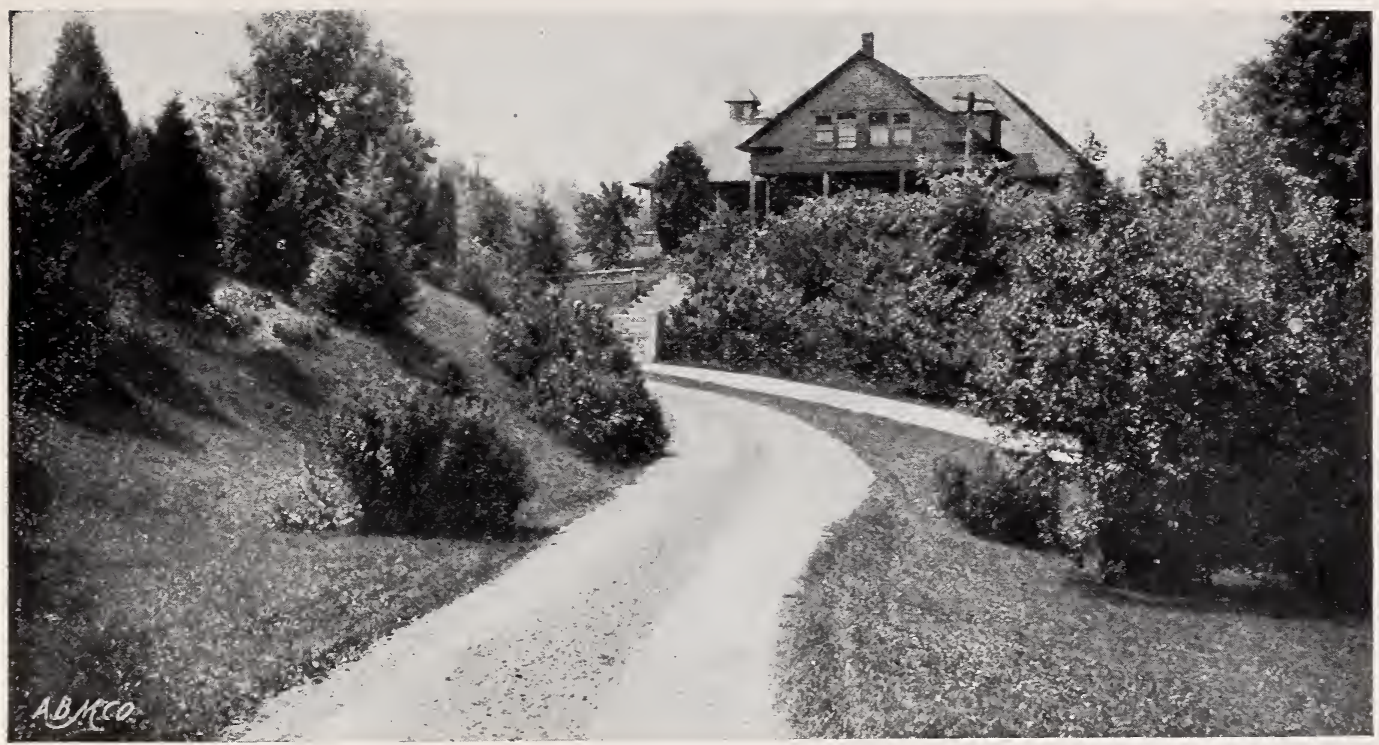

\section{Flowering Deciduous Shrubs}

It is my aim to produce everything in Flowering Shrubbery that is useful, hardy, and worthy of cultivation in this climate. Flowering Shrubs take predominance in all plans for landscape decoration, be the grounds large enough to be termed an "estate," or be they only a home garden or "yard." Without shrubbery no landscape effects can be created; but with a judicious selection, properly planted, any property can be enhanced in beauty and value. Properly arranged shrubbery does not encroach on the lawn; it rather gives it an appearance of increased size. As screens to hide fences or unsightly objects, and for giving an air of privacy, its use is indispensable. If care is oiven in selecting, flowers can be had from early spring until late fall.

\section{Acacia Rose}

Moss Locust (Robinia Hispida). A small, hardy shrub with bristly branches. Flowers rose color, very showy in loose nodding racemes. Good plants, 75 cts.

\section{Flowering Almond. Amygdalus}

One of the early blooming shrubs producing handsome little flowers in great profusion. It is one of the most beautiful little shrubs we have. 50 to $75 \mathrm{cts}$.

Double Red-flowering Almond (Amygdalus Chinensis rubra flora plena).

Double White-flowering Almond (Amygdalus Chinensis alba flora plena).

\section{Althea. Hibiscus Syriacus}

Commonly known as Rose of Sharon.

Strong, erect-growing shrub, of symmetrical habit. Very desirable for flowering in late summer, when color is especially desirable. The beautiful colors of the different varif ties contrast admirably with each other. 50 cts. to $\$ 1.00$.

Hibiscus Syriacus anemonaeflorus. Double flowers. Dark vinous red.

H. S. Boule de Feu. Very double, bright red.

H. S. Comte de Flandre. Double, rosy-white.

H. S. Jeanne d'Arc. Double white, exterior rosy.

H. S. Lady Stanley. Semi-double, rosy-white.

H. S. purpureus foliis variegatis. Dark red; leaves variegated.

\section{Azaleas}

Azaleas are the most showy and gorgeous of dwarf-flowering shrubs. Effective when

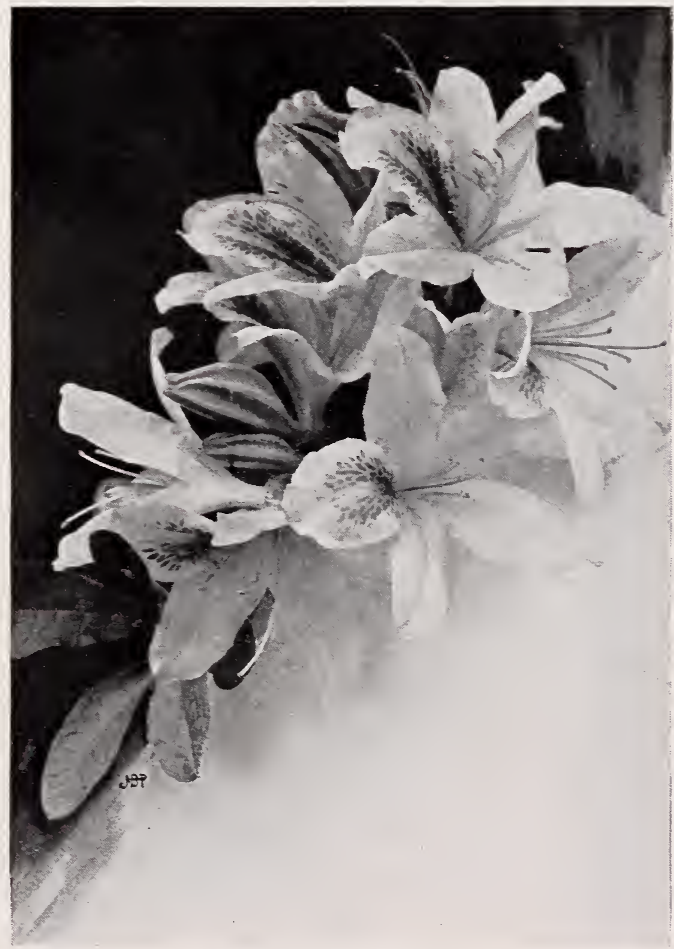

AZALEA MOLLIS. 


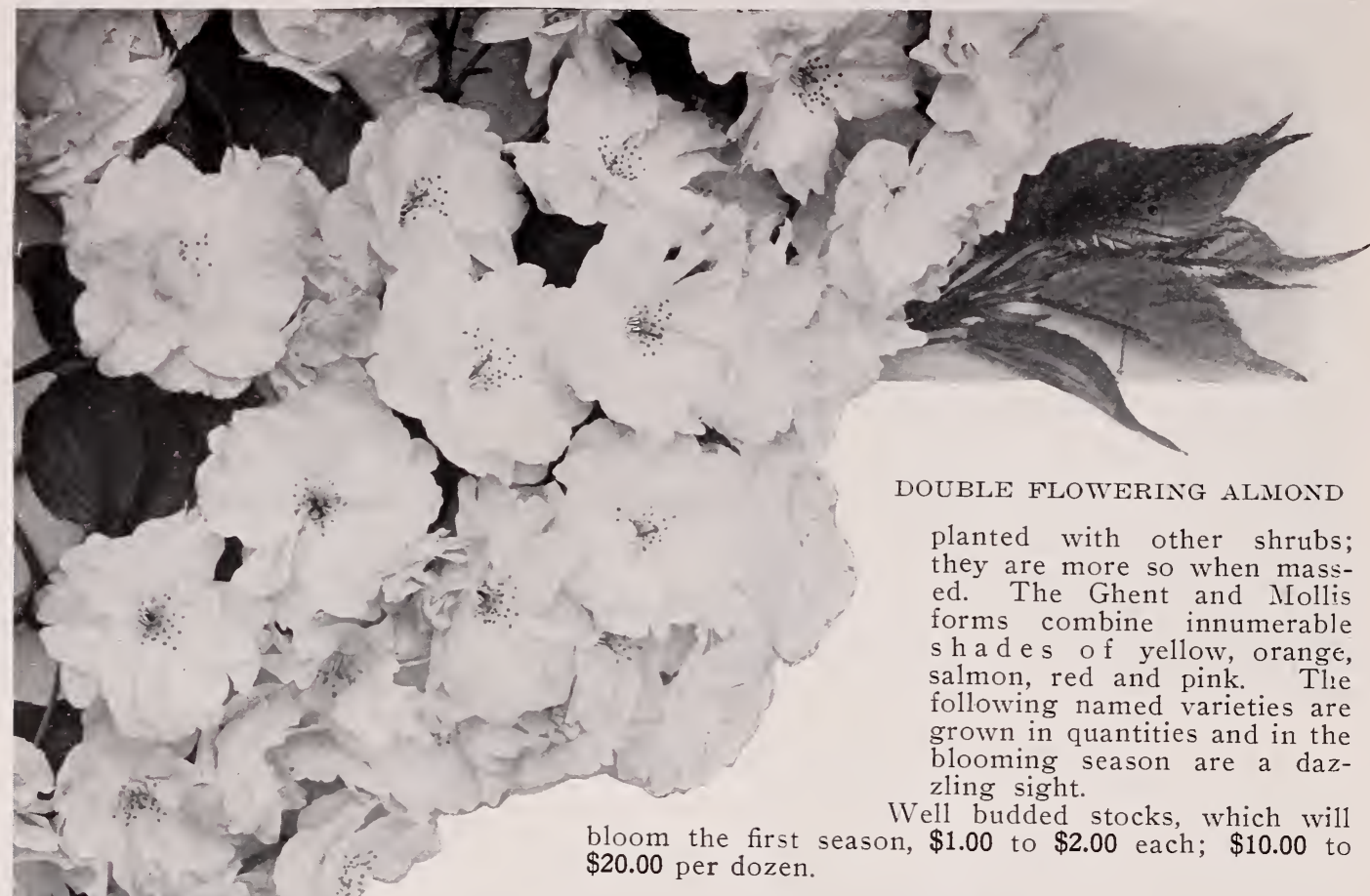

\section{Azalea Mollis}

Baron Edmund Rothschild. Red.

Comte de Kerchove. Rosy-pink.

Comte de Papadopoli. Salmon-red.

Comte de Quincy. Fine yellow.

Elizabeth. Claret.

Isabelle van Houtte. Light yellow.

Queen Sophia. Orange-red.

\section{Azalea Mollis. Var. Sinensis}

Anthony Koster. Finest golden-yellow.

Anthony Koster. Finest Hugo Koster. Salmon. golden-yellow. N. Beets. Deep orange.

Franz van der Bom. Salm- Dr. Reitenbach. Salmon. on.

\section{Hardy Ghent Azaleas. Azalea Pontica}

Aurore de Royghem. Soft rose.

Bouquet de Flore. Soft rose.

General Trauff. Soft violet-red.

Gloria Mundi. Bright orange.

Pallas. Bright red.

Sang de Gentbrugge. Bright carmine.

\section{Barberry. Berberis}

Common Barberry (Berberis vulgaris). Of erect growth and with prickly stems, bearing pretty yellow flowers in May. Fruit purplish-red, Japanese Barberry (Berberis Thunbergii). Of very dense, dwarf, spreading habit. Foliage neat and abundant, coloring gorgeously in autumn. abundant and adherent. Makes a good hedge. 35 cts. each.

One of the very best shrubs extant. Makes an excellent ornamental hedge. Scarlet fruit adherent nearly all winter. 50 cts.

Purple Barberry (Berberis vulgaris purpurea). A desirable purple-leaved shrub of upright habit and prickly stem, bearing an abundance of yellow flowers in May, and reddish-purple fruit in autumn, adherent nearly all winter. $50 \mathrm{cts}$. Low price in quantity. (See also Hedge Plants.) Other varieties, see Broad-leaf Evergreens.

\section{Bladder. Senna Colutea}

Colutea arborescens. A large-growing shrub, bearing yellow pea-shaped flowers in early June, followed by large, inflated seed pods. $75 \mathrm{cts}$. 


\section{Broom. Genista}

Andreana (Genista Andreana). A fine hybrid. Flowers are deep yellow, with a velvety maroon splash. New and attractive. $75 \mathrm{cts}$. to $\$ 1.50$.

Scotch Broom (Genista scoparia). R a pid growing shrub, trusses of bright yellow flowers in e arly spring. $50 \mathrm{cts}$.

Spanish Broom (Genista Juncea). A most beautiful, erect-growin $\mathrm{g}$ sh r ub, almost leafless; st e m s of vivid green, and when laden with its profiusion of golden yellow flowers, it forms a conspicuous object. It blooms all summer, when color is most desirable. See ill ustration. Introduced by this nursery. 75 cts. to $\$ 1.50$.

White Broom (Genista alba). A fine hardy variety, attaining good size. Blooms profusely in early spring. 50 cts. to $\$ 1.00$.

\section{Bush Honeysuckle. Chamaecerasus (Lonicera)}

Fragrant Upright Honeysuckle (Chamaecerasus (Lonicera) fragrantissima). A beautiful, almost evergreen shrub, with dark green foliage and very fragrant white flowers which appear before the leares. One of the most desirable flowering shrubs. 50 cts.

\section{Pink Tartarian Honeysuckle. Chamaecerasus Tartarica Rosea}

Red Tartarian Honeysuckle (Chamaecerasus Tartarica rubra). Large bushy. shrubs with upright branches. Flowers pink and red in great profusion in late

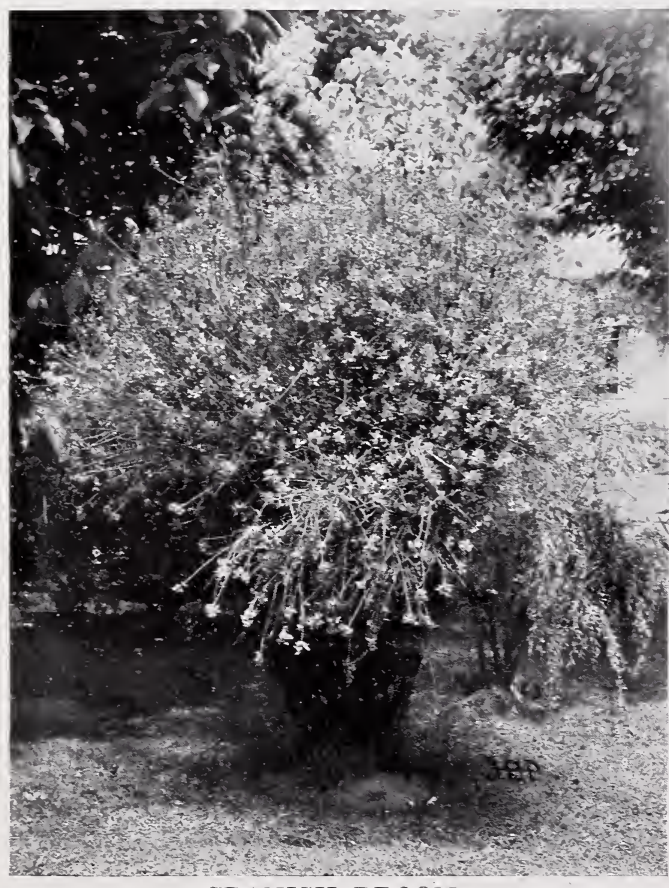

SPANISH BROON. spring, followed by red berries which hang until fall. Strong plants, 50 cts.

\section{Blue Spirea. Caryopteris}

Blue Spirea (Caryopteris Mastacanthus). A neat little shrub, with fragrant, blie, verbenalike Howers. Valued for the lateness of its bloom. If killed back in winter, new shoots will spring up and flower the first season. Nuch admired. 50 cts.

\section{Ceanothus}

Ceanothus hybridus, Gloire de Versailles. Hybrid Ceanothus. A handsome late-flowering shrub of garden origin. The erect or spreading branches reach a height of 4 to 8 feet. and are furnished with dark green rugose leaves. Flowers light blue, in large, showy panicles. 75 cts.

See Snowberry.

\section{Coralberry}

\section{Cotoneaster}

See Broad-leaved Evergreens.

False Indigo. Amorpha Fruticosa

A strong growing shrub, 6 to 10 feet high, with finger-like spikes of indigo colored flowers, three or more spikes in a bunch; blooms early in June. 75 cts. 


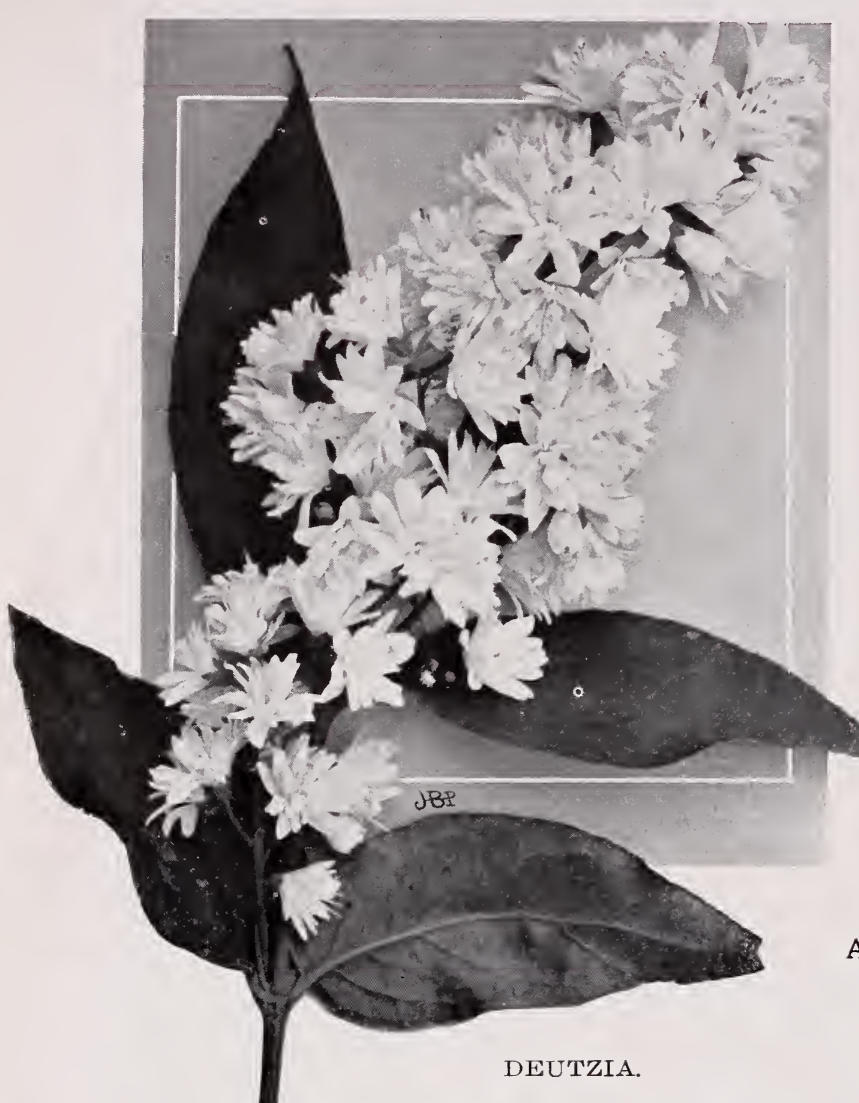

Flowering Currants. Ribes

Gordon's Currant (Ribes Gordonianum). A hybrid between Aureum and Sanguineum. A hardy and profuse blooming shrub, bearing pink flowers on pendant branches in May. 50 cts.

Red-flowering Currant (Ribes sanguineum). Blooms abundantly in May bearing bright pink, almost carmine flowers. Native of Oregon. 50 cts.

Yellow-flowering Currant (Ribes aureum). Flowers yellow, with pink stamens, and sweet-scented. Viery good habit. Bears edible fruit. 50 cts.

\section{Deutzia}

Double Pink (Deutzia crenata fl. pl. rosea). Similar to the Double White, but with one or more of the outer petals rosy-purple. Very showy. 50 cts.

Double White (Deutzia crenata fl. pl. alba) Flowers double pinkish-white, in spikes 5 inches long; tall and of rapid growth. $50 \mathrm{cts}$.

Lemoine's Deutzia (Deutzia Lemoinei). A small shrub, with spreadino branches, usually about 3 feet tall; of garden origin. Leaves bright green, 2 to 3 inches long. Flowers white, in large compound clusters of panicles. Very vigorous and floriferous. 50 cts.

\section{Dogwood. Cornus}

The Dogwoods range in size from small shrubs to large trees like our native Oregon Dogwood (Cornus Nuttali). Nearly all of them are valuable, but there is so much variation that it is sometimes hard to specify the most desirable for a given purpose or effect. In some varieties the flower ranks first, in others the foliage, and in still others the chief value is in its colored bark or fruits. The following are Shrubs. For Trees, see Deciduous Trees.

Golden Barked (Cornus stolonifera aurea). Small creamy-white flowers. Its chief beauty is in the bright yellow bark of twigs and branches. Planted with the red branched varieties, marked contrasts are secured. Very effective in winter landscapes. 75 cts.

Red Siberian (Cornus Siberica). Clusters of creamy-white flowers in spring. Has bright blood red bark in winter and early spring, making it very effective. 75 cts.

Yellow Leaved (Cornus Spaethii). A fine new variety of Dogwood. Large green leaves, variegated with pale yellow. $75 \mathrm{cts}$.

\section{Elder. Sambucus}

Hardy vigorous shrubs with showy flowers and profusion of berries. They thrive best in moist loamy soils, and are well adapted for waterside and border planting.

American Elder (Sambucus Canadensis). Hardy shrub with numerous stout stems filled with pith; compound foliage of 5 to 10 bright green leaflets, above which is borne large flat clusters of white fragrant flowers in early summer. Berries purplishblack in great profusion, often used for home-made, old-fashioned elderberry wine. A showy shrub worthy of extensive cultivation. $50 \mathrm{cts}$. to $\$ 1.00$.

Cut-leaved Elder (Sambucus nigra laciniata). Deeply laciniated foliage; very attractive. 50 cts. to $\$ 1.00$.

Golden-leaved Elder (Sambucus foliis aureis). The finest in rich coloring of all the hardy shrubs; the entire foliage remaining a bright, beautiful golden color throughout the summer. Growth and habit slower and more compact than other Sambucus. A shrub that should be in every collection. $75 \mathrm{cts}$.

Red-berried Elder (Sambucus racemosus) White flowers, followed by bright red berries, very showy in early summer. A good companion to American Elder, and often has ripe berries when latter is in bloom. 75 cts. to $\$ 1.50$.

\section{Deciduous Oleasters (Olives) Elaeagnus}

Silver Thorn (Elaeagnus longipes). A beautiful shrub from Japan, of a dense bushy growth, belonging to the Olive family of plants, attaining a height of 5 to 6 feet. The foliage is bright green above and silvery-white beneath. The blossoms are very abundant, hanging in wreaths along the branches, and are followed by fruits as plentiful. They are pale yellow in color and appear in May. The berries ripen in 


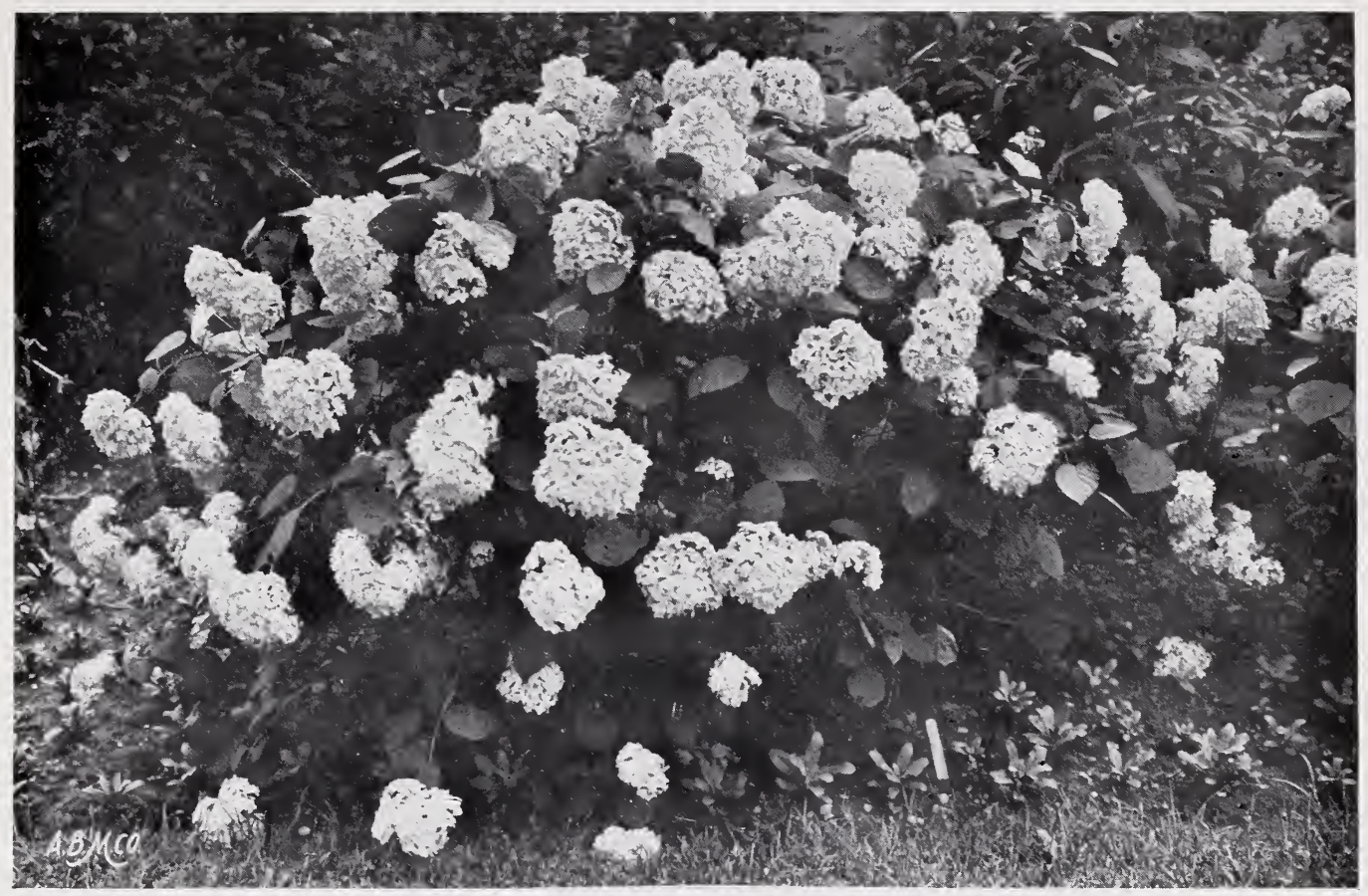

HYDRANGEA ARBORESCENS.

July, are olive-shaped, about the size of large currants, and bright scarlet. The fruit can be cooked like cranberries. This is a most useful and ornamental shrub, attractive at all seasons of the year. 75 cts.

\section{Enkianthus}

Enkianthus Japonica. A fine lawn and open ground shrub, ramifying in horizontal layers, white, pendulous flowers. Autumn foliage is gorgeous. From Japan. New. \$1.00.

\section{Burning Bush. Euonymus}

Broad-leaved Euonymus (Euonymus latifolius). Broad, glossy foliage and large, bright carmine-red fruit. $50 \mathrm{cts}$.

European Euonymus (E. Europæus). A large shrub or tree, bearing rose-colored fruit in autumn. Fine. 75 cts.

\section{Filbert. Corylus}

See also Nut Trees.

Cut-leaf Filbert (Corylus avellana laciniata). Deeply cut foliage. Very ornamental. 75 cts.

Purple-leaved Filbert (Corylus Avellana folia atropurpurea). A very conspicuous shrub, with large, dark purple leaves; distinct and fine. Fine for planting with other shrubbery, or as a single specimen. $75 \mathrm{cts}$.

\section{French Mulberry. Callicarpa}

See also Trees.

French Mulberry (Callicarpa Americana). With purple berries, produced in clusters; very effective in fall and early winter. This beautiful native plant is not sufficiently appreciated. 50 cts.

Globe Flower. Kerria (Corchorus)

Globe Flower (Kerria Japonica flora pleno).
Double flowering Corchorus. A mediumsized shrub, with double, yellow flowe $50 \mathrm{c}$.

\section{Golden Bell. Forsythia}

One of the first plants to flower in early spring, blooming before the leaf buds burst on other plants, and but few can surpass the splendor and brilliancy of the Forsythia.

They thrive in almost any fertile soil, but should be planted where they will receive the full benefit of early spring sunshine.

Dark Green Golden Bell (Forsythia viridissima). Blooms early in spring, before the leaves appear, when it is covered with golden, bell-like flowers. $50 \mathrm{cts}$.

Drooping Golden Bell (Forsythia suspensa). Like Forsythia Fortunei, but somewhat drooping in habit. $50 \mathrm{cts}$.

Fortune's Golden Bell (Forsythia Fortunei). Bark bright yellow; blooms in dense masses of golden flowers in April. 50 cts.

Hybrid Golden Bell (Forsythia intermedia). Flowers bright golden; foliage glossy green, like Viridissima, but hardier than that variety. Valuable. $50 \mathrm{cts}$.

\section{Hardy Orange. Citrus}

Citrus trifoliata. A hardy variety of Orange. As an ornamental flowering plant, few are more desirable. The plant grows to a height of 10 to 15 feet, is very bushy and thorny; foliage trifoliate, retained quite late, but not an evergreen here; however, the vivid green wood gives it an evergreen appearance. Flowers appear in great profusion in early March, and a second and third crov are produced during the summer. The bright golden fruit is retained during winter, which makes it a showy garden feature. 75 cts. 


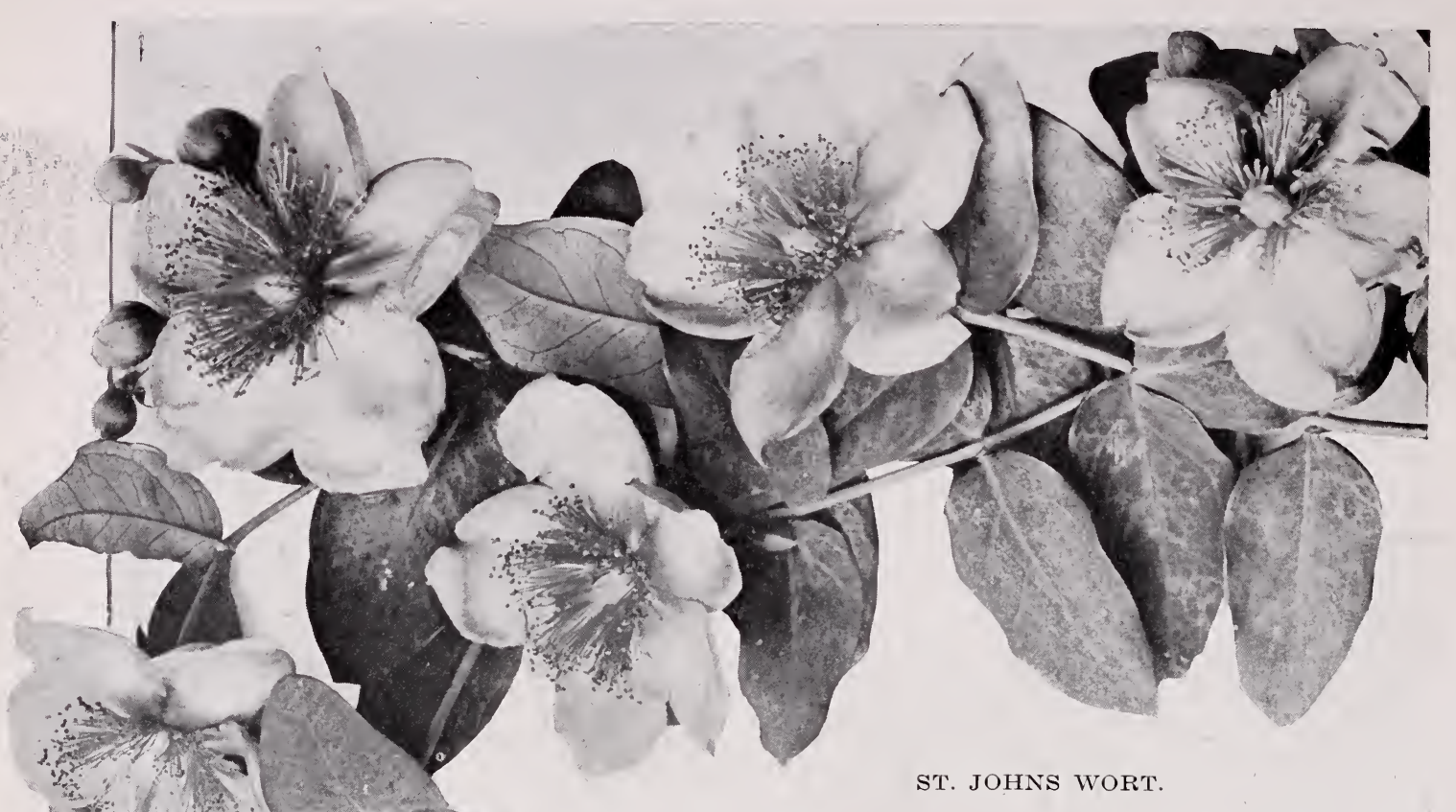

\section{St. Johns Wort. Hypericum}

Ornamental free-flowering shrubs-with orange yellow flowers blossoming in summer. They thrive in any well drained soil, either in full sun or partial shade; are low growing and particularly valuable for borders or low mass effects on hillsides. They should be cut back severely in late winter.

Aaron's Beard (Hypericum calycinum). A low shrub about a foot high; flowers large and showy. A capital ground cover. Thrives best in partial shade. $50 \mathrm{cts}$.

Gold Flower (Hypericum moserianum). Grows 1 to 2 feet high; numerous branches with dark green foliage, valued for its persistent and beautiful bloom. Flowers are large, rich yellow from July to fall. $50 \mathrm{cts}$.

\section{Hydrangea}

Hydrangea arborescens sterilis. Hills of Snow - a hardy, handsome, upright shrub, loaded with flowers like Snowballs that continue in blossom a large part of the summer. $75 \mathrm{cts}$.

Hydrangea paniculata grandiflora. This is a grand plant, showy and attractive, lasting in bloom for months. Without question, the finest hardy blooming shrub. Grows several feet high. It blooms in July, at a time when flowers are scarce. The flowers are pure white, afterward changing to pink, and are borne in immense clusters. Will bloom same season planted. 50 cts; tree form, $\$ 1.00$.

H. hortensia Japonica rosea. Globular rose flower. $50 \mathrm{cts}$. to $\$ 1.00$.

Otaksa. Immense trusses of pink or blue flowers. $50 \mathrm{cts}$. to $\$ 1.00$.

Ramis pictis. Branches dark purple; flowers pink or blue. $75 \mathrm{cts}$. to $\$ 1.25$.

Stellata rubra. Free-blooming lilac flowers. $50 \mathrm{cts}$. to $\$ 1.00$.

Thomas Hogg. Flowers pure white. $50 \mathrm{cts}$. to $\$ 1.00$.

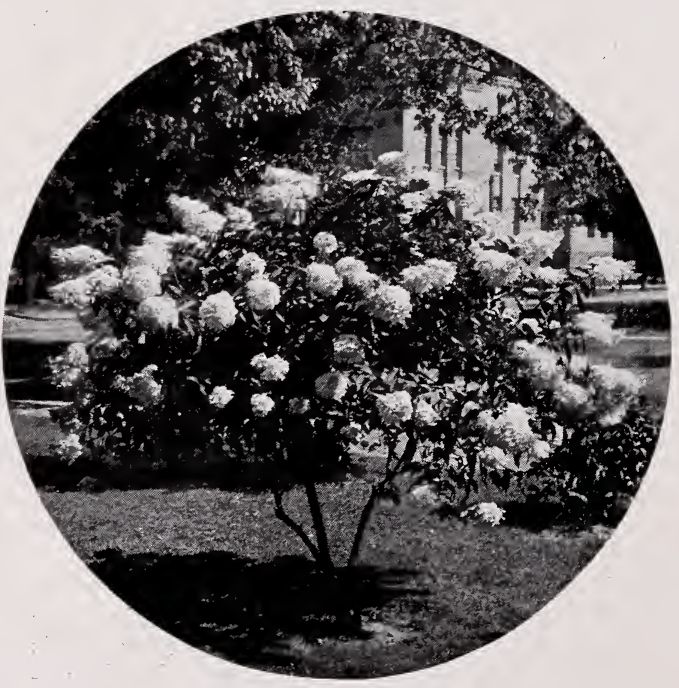

HYDRANGEA PANICULATA GRANDIFLORA 
Japan Quince. Cydonia

Scarlet Japan Quince (Cydonia Japonica). Bright scarletcrimson flowers in great profusion in the early spring. One of the best hardy shrubs, thorny, and of compact growth. Also one of the best deciduous hedge plants. (See Hedge Plants.) 50 cts. to $\$ 1.00$.

White Japan Quince ( $\mathrm{Cy}$ donia Japonica nivalis). A very beautiful variety, with delicate white and blush flowers. 50 cts. to $\$ 1.00$.

\section{Lilacs. Syringa}

No place is complete without some of these. A class of shrubs embracing many beautiful colors. Many of them are hardly dissimi 1 a $r$ and I o mit thos e which are not sufficiently distinct. Over thirty varieties in stock. Patrons please ask for any not mentioned.

Purple Lilac (Syringa vulgaris). Common Lilac. An old favorite. Purple fragrant flowers; large clusters. $50 \mathrm{cts}$.

White Lilac (Syringa vulgaris alba). The common White Lilac. One of the best. 50 cts.

\section{Single Grafted Varieties}

Charles X. Magnificent clusters of dark red flowers, produced in the greatest profusion. A splendid variety and one of the best to bloom. 75 cts.

Jaques Calot. Very large spikes of delicate rosypink flowers. $75 \mathrm{cts}$.

Marie LeGraye. Beautiful creamy-white flowers of immense size; bush of dwarf habit. One of the most popular white varieties. $75 \mathrm{cts}$.

\section{Double Grafted Varieties}

La Tour d'Auvergne. Violet-purple color, very large trusses. 75 cts.

Mad. Abel Chatenay. Fine white, borne in compact clusters. 75 cts.

Mad. Casimir-Perier. One of the finest whites, individual flowers and the trusses very large and deliciously scented. $75 \mathrm{cts}$. Mad. Lemoine. A grand double white variety. Vigorous habit and immense foliage. 75 cts.

President $\mathrm{C}$ arnot. Flowers erect, very prettily formed, delicate tint of pale lilac, marked with white in the center. Season of flowering very late. The most floriferous of all double lilacs and valuable for forcing. $75 \mathrm{cts}$.

President Grevy. Magnificent spikes, attaining more than a foot in length, with proportionate width, individual flowers over an inch, petals of cobalt blue, with the center more brilliant and the edges rosy. The buds are enormous and of a vinous violet-blue. 75 cts.

\section{Mock Orange}

Philadelphus (Syringa)

Hardy, fragrant, flowering shrubs that add grace, beauty and perfume to gardens and homes. Do well in any well drained soil.

Gordon's Mock Orange (Philadelphus Gor donianus). A very late bloomer, valuable for this quality. Large, fragrant white flowers. $50 \mathrm{cts}$.

Large Flowered Mock Ora nge (Philadelphus grandiflorus). A large flowered, strong growing sort, very

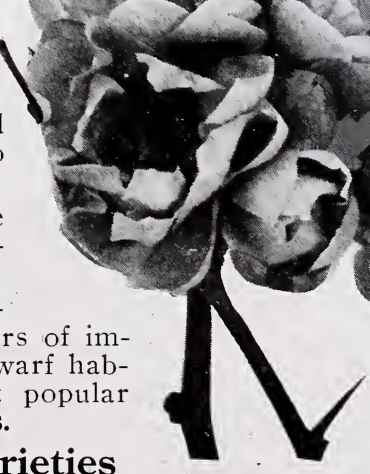
JAPAN
QUINCE. desirable. 50 cts.

\section{Pearl Bush Exochorda}

JBP

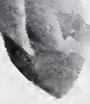

Pearl Bush (Exochorda grandiflora). Leaves bright green, pale or whitened beneath, fading with yellow tones. Flowers dazzling white, produced in numerous terminal racemes. Very showy. $75 \mathrm{cts}$.

\section{Pomegranate. Punica}

Double Flowering Pomegrana te (Punica granatum). These are among our most valuable summer blooming, tall growing shrubs. Their flowers are produced in great profusion and are very showy. $75 \mathrm{cts}$.

Punica Legrelli. A larger growing variety. Strong, double flowers. 75 cts. 


\section{Siberian Pea Tree. Caragana}

A large shrub-becoming a small tree eventually-with delicate green foliage, bearing a wealth of clusters of yellow sweet-pea like flowers in late spring. Very handsome and showy.

Siberian Pea Tree (Caragana arborescens). Strong plants. 50 to $75 \mathrm{cts}$.

Weeping Form (Caragana arborescens pendula). Weeping form of above. 75 cts. to $\$ 1.00$.

\section{Silver Bell. Halesia}

Common Snowdrop Tree (Halesia tetraptera). A small native tree, bearing most beautiful, bell-shaped flowers, similar to Snowdrop, but much larger. Blooms in May. Grown in shrub form it is exquisite. 50 cts.

Smoke Tree. Rhus or Sumac

Purple Fringe (Rhus cotinus). The well-known Smoke Tree. Of small size, round, glossy foliage. The seed vessels are of a reddishpurple, borne in great profusion. $50 \mathrm{cts}$.

Purple Fringe (Rhus cotinus atropurpurea). Similar to the preceding, except in the deeper color of the seed-vessels. A decided novelty. $\$ 1.00$.

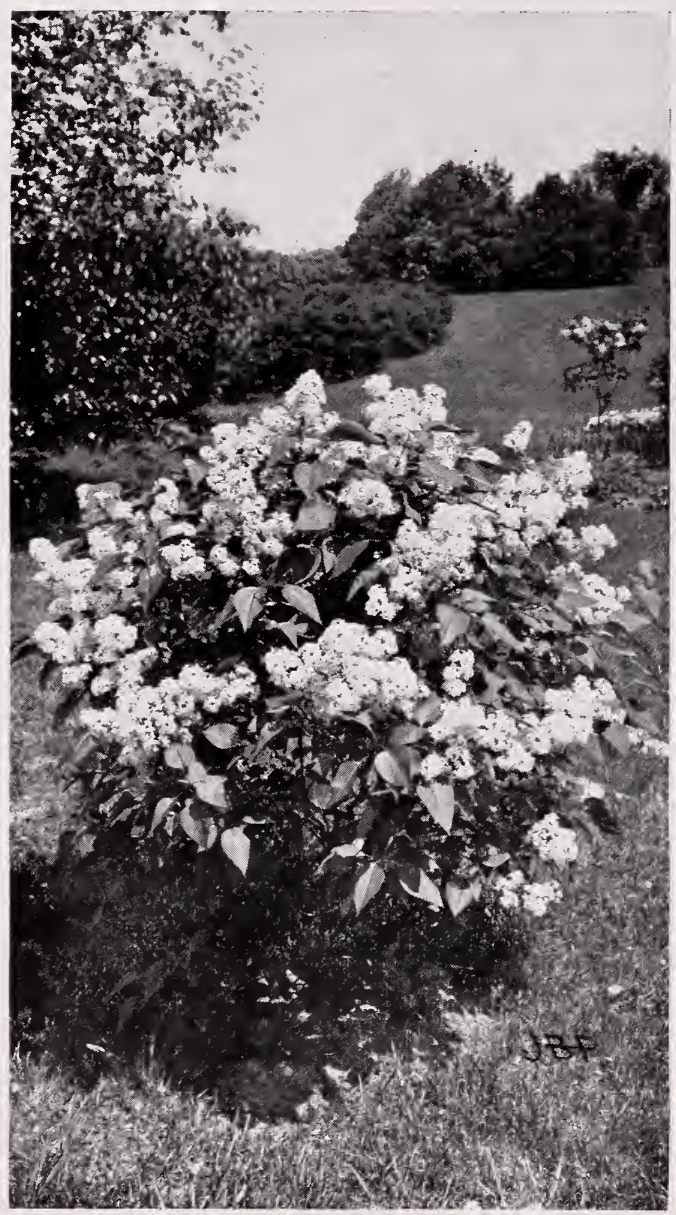

LILAC.

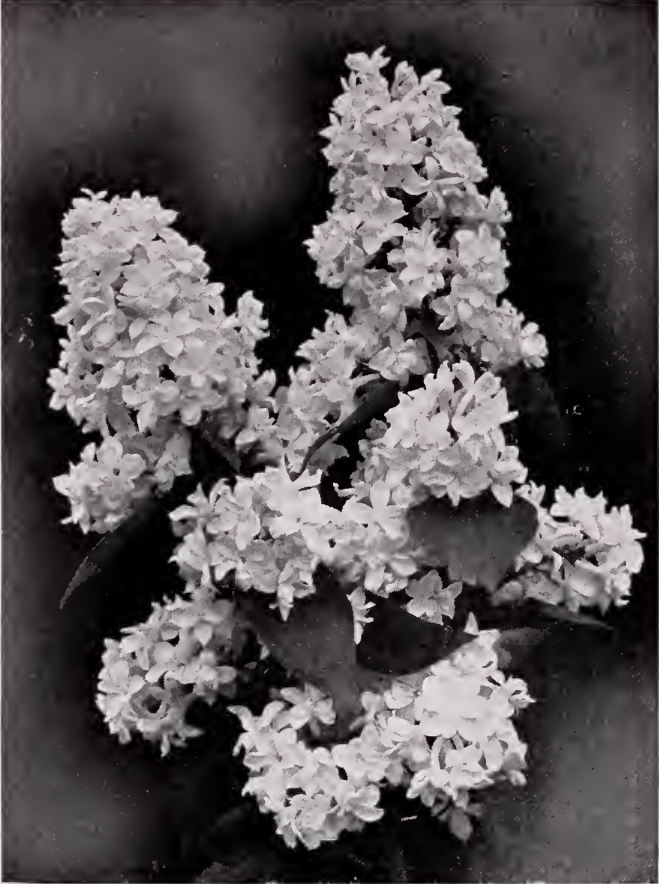

DOUBLE FLOWERING LILAC.

Smooth Sumac (Rhus Glabra). Shrub or low tree with an open crown. Leaves dark green above, light below, that turn brilliant scarlet in autumn. Flowers in large terminal clusters, followed by crimson fruits which hang on all winter. Beautiful for mass effects. $50 \mathrm{cts}$.

Cut-leaved Sumac (Rhus Glabra laciniata). A beautiful shrub, with large leaves, deeply and finely cut, and drooping graceful habit. Leaves assume a gorgeous crimson color in autumn. $75 \mathrm{cts}$. to $\$ 1.00$.

\section{Snowball. Viburnum}

Common Snowball (Viburnum Opulus sterilis). The old-fashioned Snowball that grows almost anywhere and always flowers so abundantly. In appearance it closely resembles Viburnum Opulus, but does not have the ornamental fruits. 35 cts. to $\$ 1.00$.

High-bush Cranberry (Viburnum Opulus; syn., Oxycoccus). Spreading habit. Single white flowers borne in flat, imperfect clusters. Highly valued for the brilliant red berries that cling to the leafless branches all winter, unmolested by birds. $50 \mathrm{cts}$. to $\$ 1.00$.

Japan Snowball (Viburnum plicatum). One of the best ornamental shrubs, upright and vigorous growing. It bears abundant white balls of bloom that have a beautiful setting in the deep green leaves. 50 cts. to $\$ 1.00$.

Single Japan Snowball (Viburnum tomento. sum). An elegant shrub, with beautiful dark green leaves. The white flowers, borne in flat clusters, are followed by decorative red berries, that later change to black. Valuable in shrubberies. 75 cts. 


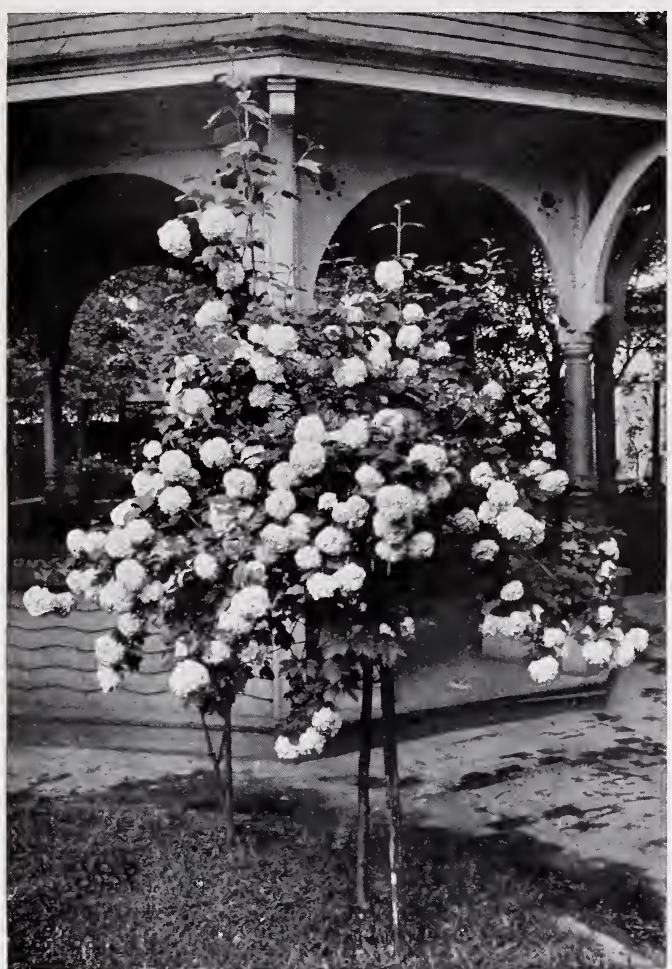

COMMON SNOWBALL.

Residence W. Merriman, 304 E. 16 North.

\section{Sumac}

See Smoke Tree.

\section{Sweet Shrub. Calycanthus}

Sweet Shrub (Calycanthus Floridus). Spice Bush, or Allspice. Remember the "shrub" we carried in our pockets in childhood days? This is the plant that bears them. An old-fashioned shrub, of strong, upright habit. Grows well in almost any soil, and in shaded or open places. Valuable for its aromatic fragrance and chocolate-colored flowers of a peculiarly agreeable odor. $\mathbf{5 0}$ cts. (See illustration.)

\section{Tamarisk. Tamarix}

Tamarisk (Tamarix Africana). Strong, slender growing, irregular shrubs, with feathery foliage and small, delicate flowers, borne profusely on gracefully bending branches in early spring. These pink flowers are very attractive. 50 cts.

Tamerix hispida estivalis. A new variety of vigorous growth. In May the branches are covered half of their length with numerous bright carmine-pink flowers, which gives the plant a most pleasing appearance. Awarded first prize at the Paris International Exposition. Introduced by this $n \mathrm{u} \mathrm{r} \mathrm{s} \mathrm{-} \mathrm{ery.} \$ 1.00$.

$\mathrm{J}$ a $\mathrm{p} \mathrm{a} \mathrm{n}$ - ese Tamarisk. ( $\mathrm{T} \mathrm{a} \mathrm{m}-$ erix plumosa. or Japon- 3 ica). Of med i u m height; foliage very

\section{Snowberry. Symphoricarpos}

Snowberry (Symphoricarpos racemosus). Much valued for its white berries, borne abundantly in autumn. Especially conspicuous in masses. 35 to $50 \mathrm{cts}$.

Snowberry, Red-fruited (Symphoricarpos vulgaris rubra). Red fruit-not so large as the preceding, but more abundant. Habit of plant graceful. 35 to 50 cts.

\section{Spirea}

Anthony Waterer (Spirea Bumalda). Identical with Anthony Waterer, except the flowers, which are bright rosy-crimson, showy and attractive. Observation satisfies us that this is the best all-summer blooming dwarf shrub in cultivation. 50 cts.

Bridal Wreath (Spirea prunifolia). Bears handsome double white flowers all along the branches in early spring before the leaves are expanded. Foliage colors finely in autumn. 50 cts.

Thunberg's Spirea (Spirea Thunbergii). Low-growing, rounded form, delicate, drooping, yellowish green lanceolate foliage, which takes and retains late the most lovely tints in autumn. Small, abundant white flowers in March, the most charming of a 11 low-growing shrubs. $50 \mathrm{cts}$. to $\$ 1.00$. Specimens, $\$ 1.00$ to $\$ 1.50$.

Van Houtte's (Spirea Van Houttei). Habit of plant graceful, bearing white flowers in great abundance in later May. One of the best. 50 cts.. Specimens, $\$ 1.00$ to $\$ 1.50$.

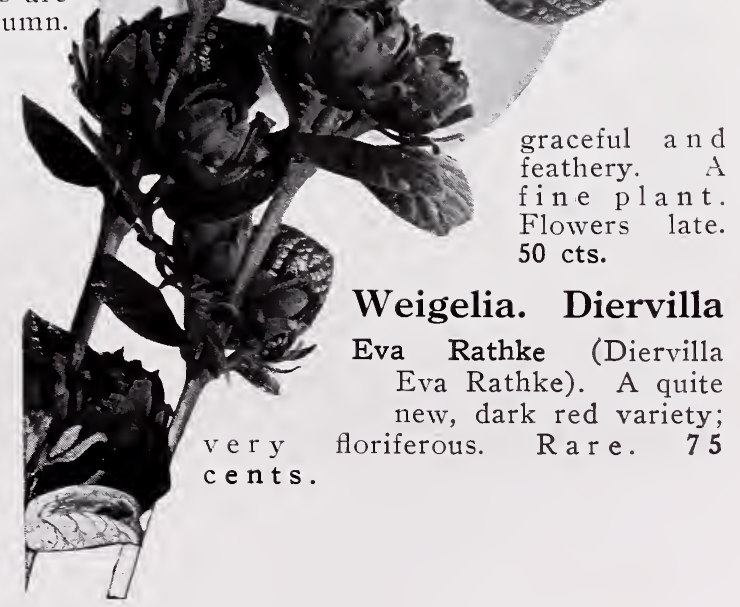




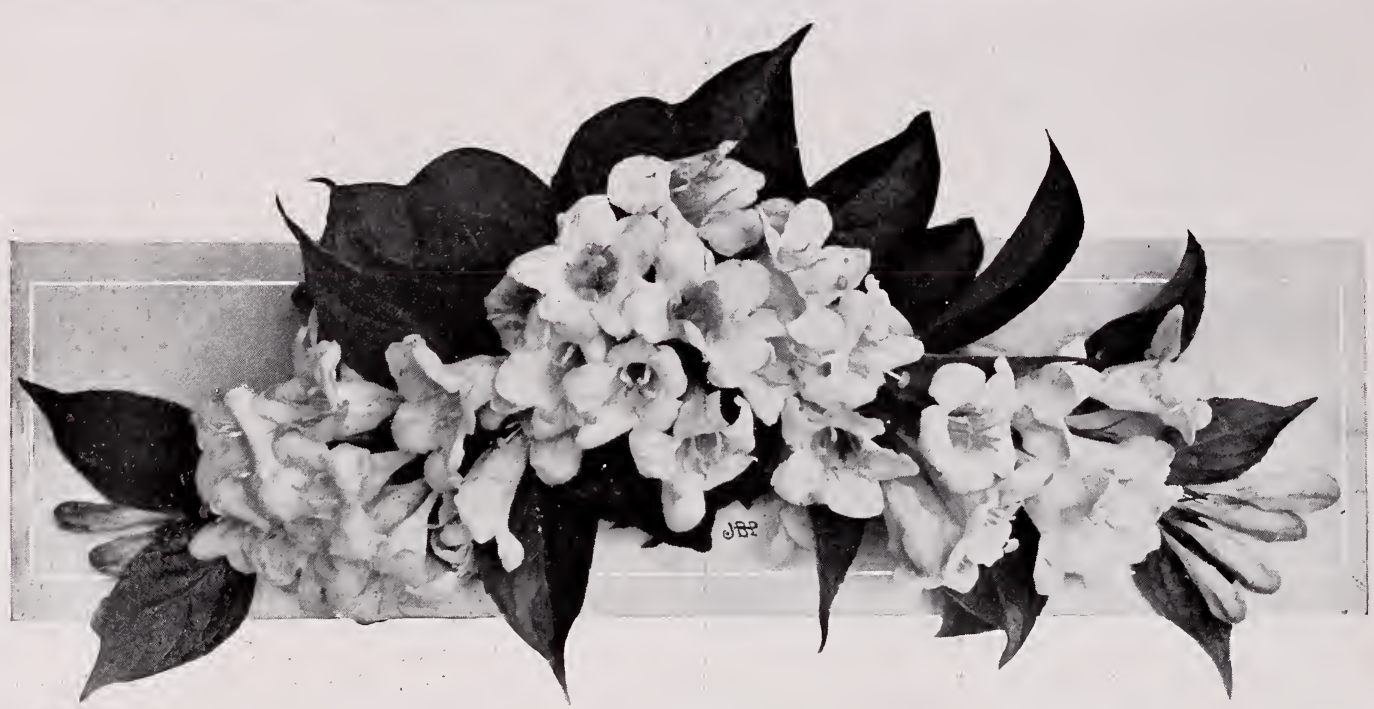

WEIGELIA.

Pink (Diervilla rosea). An elegant shrub, with fine, rose-colored flowers; introduced from China. Of erect, compact growth; blossoms in June. 50 cts.

Variegated (Diervilla rosea variegata). A neat, dwarf shrub, valuable for the clearly defined variegation in its leaves of green, yellow and pink; very effective and useful. Flowers similar to rosea,- - delicate rose and pink. This is one of the finest variegatedleaved shrubs known, and is greatly esteemed. $50 \mathrm{cts}$.

\section{Broad Leaved}

After Shade Trees the Broad-leaved Evergreens demand first attention in preparing planting plans; be it only a small bit of lawn that you wish to make attractive during the entire year or for a broad estate, taking hundreds of shrubs. They can sup-

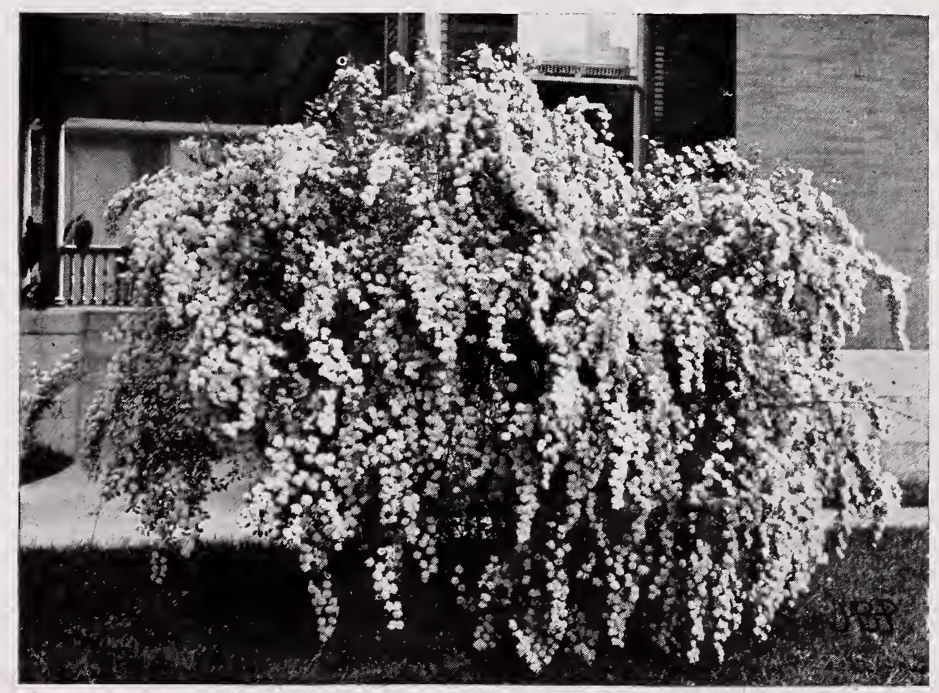

SPIREA VAN HOUTEI.
White (Diervilla candida). This is the hardiest and best of all the family. Vigorous and fine in habit; the long, tubular, white flowers are produced from June on, all through the summer. 50 cts.

\section{White Fringe. Chionanthus}

Chionanthus Virginica. Another very desirable large-growing shrub, bearing racemes of fringe-like white flowers in latter May. Its purple fruit, too, is highly ornamental, as is also its deep, lustrous green foliage. $\$ 1.00$.

\section{Evergreens}

ply both background and foreground for the somber winter picture or for the summer floral display. They thrive in shady or partially shaded places, giving finest foliage effects when so grown-with better flower perhaps when grown in the sun.

Our climatic conditions in $\mathrm{Pa}$ cific Northwest are particularly congenial to this class of shrubbery and aid in obtaining wonderfully pleasing effects in foliage and flowers. Our Oregon State flower - Oregon Grape-and the State of Washington's choice of the native Rhododendron, prove conclusively the esteem in which they are held. My stock in these is particularly fine, home grown, or thoroughly acclimated, and good results can be depended upon.

\section{Abelia}

Mexican Abelia (Abelia floribunda). An evergreen shrub, with small, deep green leaves. Flowers pale pink or rosy purple, about 2 inches long, borne in one to three-flowered 
clusters. The blossoms begin to open in early summer and continue until autumn. $75 \mathrm{cts}$.

Japanese Laurel Aucuba

Japanese Laurel (Aucuba Japonica). A medium-sized $\mathrm{sh}$ r u b, w it h berries, dark glossy leaves, unaffected by smoke and dust. Excellent for city planting. Berries scarlet, in showy contrast with the foliage. Fine plants, $\$ 1.50$ to $\$ 2.00$.

Gold Dust Laurel (Aucub a Japonica aureomaculata). A form with yellow spotted leaves and red berries. A strikingly attractive plant, and one that is much used for jardinieres a n d OREGON GRA
window-boxes. Fine plants with berries.

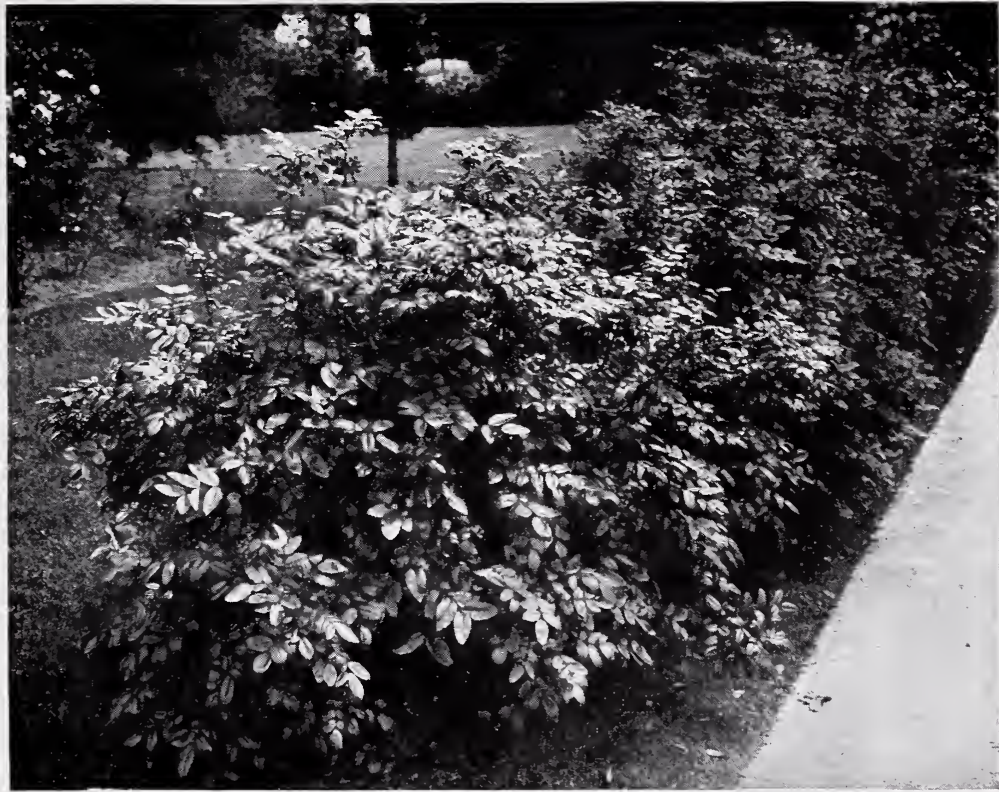
$\$ 1.50$ to $\$ 3.00$.

\section{Azaleas}

Crimson Azalea (Azalea Asahi). From Japan. Flowers a dazzling crimson; small evergreen foliage light delicate green in spring, darkening as summer season advances and becoming rich purplish-brown during winter season. Better than Azalea amoenathe Eastern Crimson Azalea. Introduced by this nursery a few years ago. Beginning with but ten plants, it has now grown so into popular favor that sales during last season amounted to several hundred plants. It is fine either as single specimen or for mass effects, and is destined to become a general favorite, and no grounds should be without it. $\$ 1.25$ to $\$ 1.50$ each; $\$ 12.00$ to $\$ 15.00$ per dozen.

\section{Barberry. Berberis}

Box-leaved Barberry (Berberis buxifolia; syn., dulcis). A small shrub, with spiny branches. Leaves simple, about an inch long, dark green. Flowers orange-yellow, solitary, on long stalks. Fruit nearly round, dark purple, or nearly black. Graceful and freeflowering shrub, and one of the hardiest of the evergreen species. $50 \mathrm{cts}$.

Darwins (Berberis Darwini). A small shrub, with silky brown branches. Leaves usually with three spiny points at the tip, dark glossy green. Flowers orange-yellow, often tinged with red, borne in many-flowered pendulous racemes. Berries dark nurple. 50 cts.

Berberis aquifolium. See Oregon Grape-Mahonia.

\section{Bay Trees. Laurus Nobilis}

This beautiful tree is commonly cultivated as a tub-plant; and is used universally for dec- orating. It will stand considerable frost without injury and is hardy out of doors here in Portland all the year, excepting the few days of freezing weather, when tubplants should be taken in. Open ground plants flourish without protection. A rich, porous soil with good drainage and amnle water makes a congenial medium, whether the plants are confined in tubs r, r set out in the open ground. Handsome, ornamental trees usually trained to formal lines. The standard and pyramidal forms, such as are usually sold in tubs, are imported from Belgium. In the fall of 1904 this nursery imported thirty trees, which were placed in the Hotel Portland. Since that time nearly 1,400 more have been sold. Visitors to Spokane, Wash., have noticed the Bay Trees at Davenport's. The Fairmont, Palace, and other hotels in San Francisco; hostelries in Portland, Seattle, Tacoma and elsewhere, have used these trees with satisfaction, and most of them were sunolied by this establishment.

Standards and Pyramids, in tubs ready for placing $\$ 10.00$ to $\$ 20.00$ each, according to size. Write for special quotations and sizes. Small field-grown plants, 2 to 4 feet high, untrimmed, $\$ 1.00$ to $\$ 2.50$.

\section{Boxwood. Buxus}

Common Boxwood (Buxus sempervirens). For open-ground planting or in tubs for decorative purposes. Tubs are additional.

Pyramids, 11/2 to 2 feet, $\$ 1.25$; Pyramids, 21/2 to 3 feet, $\$ 2.50$; Pyramids $3 \mathrm{r} / 2$ feet, $\$ 3.00$; Pyramids, 4 to 5 feet, $\$ 5.00$. Standard form, 15 to 18 inches diameter, $\$ 2.50$; Standard form, 18 to 24 inches diameter, $\$ 4.00$.

Dwarf (Buxus suffruticosa). Small, round specimens, 12 to 24 in. high, 75 cts. to $\$ 1.50$. Small size for borders, 5 to 8 in., $\$ 2.50$ per dozen. 


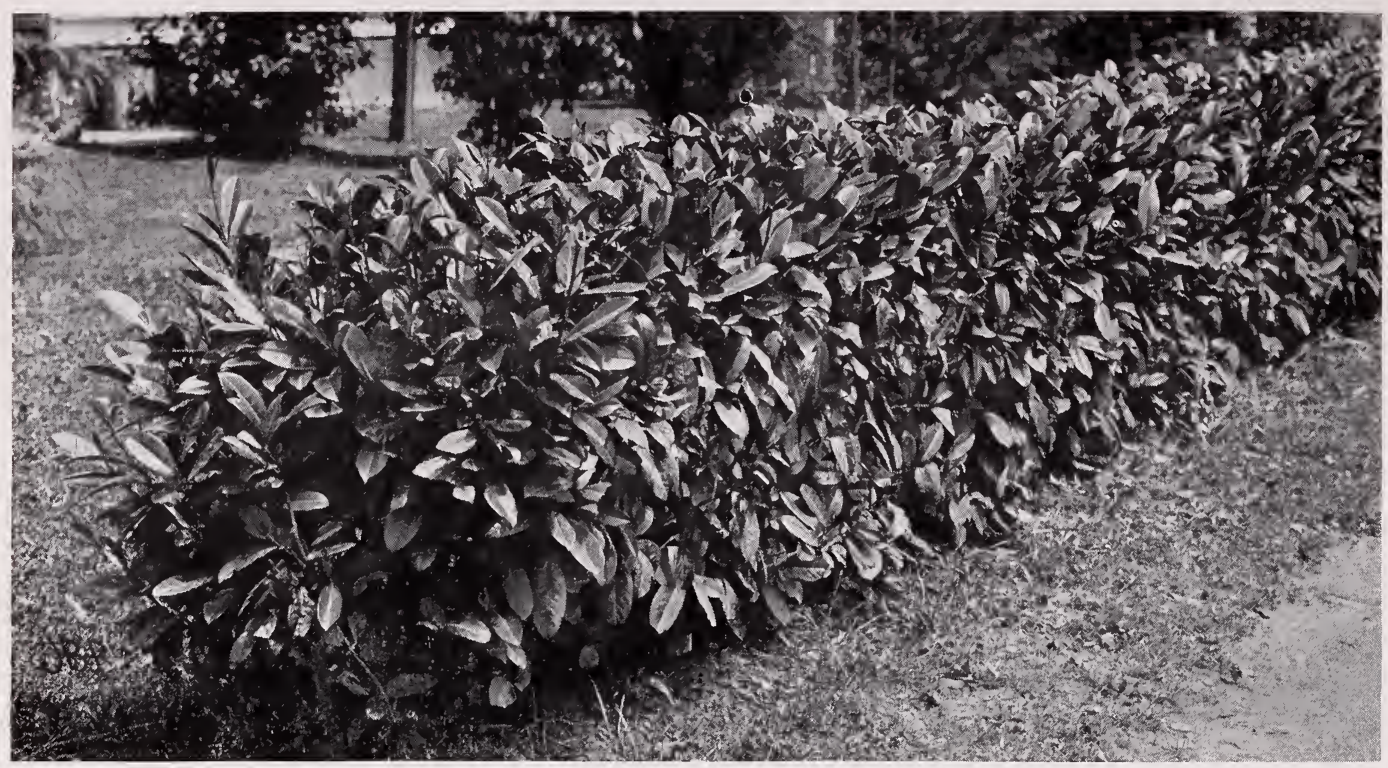

ENGLISH LAUREL HEDGE.

\section{Camellia}

Evergreen shrubs, with handsome foliage and showy flowers. Cultivated in the open air in Portland. They thrive in fertile porous soils, either in sun or partial shade.

Camellia Japonica. A shrub with shining dark green leaves and beautiful waxy flowers of great substance and durability. Native of China and Japan. I offer a choice assc:tment of varieties embracing double-flowered forms, white, pink, and variegated. 75 cts. to $\$ 1.50$. A limited number of large specimens-4 feet up, at $\$ 3.00$ to $\$ 5.00$ each.

\section{Cotoneaster}

Prostrate Cotoneaster (Cotoneaster horizontalis). A low shrub with almost horizontal branches. Leaves dark green, flowers pinkish-white, solitary or in pairs; fruit bright red. Good for covering rockeries. 50 to 75 cts.; $\$ 5.00$ to $\$ 7.50$ per dozen.

Small-leaved (Cotoneaster microphylla). Smaller shrub than C. horizontalis, minute evergreen leaves; flowers white, usually solitary, blooming in late spring. Has bright red berries, well distributed along branches, lasting greater part of winter. Very pretty and unique among rock work, tops of retaining walls, etc. 50 to $75 \mathrm{cts} ; \$ 5.00$ to 7.50 per dozen.

Shining Leaved (Cotoneaster Simoni). Pretty shrub with small bright leaves, semi-persistent or at times wholly evergreen. Prized for the white, slightly pinking flowers and bright red fruits. 75 cts.

\section{Daphne}

Pink Daphne (Daphne odora). Fine evergreen shrub, blooming very early. Pink flowers that are wonderfully fragrant. $\$ 1.00$ to $\$ 1.50$.

White Daphne (Daphne odora). Same as above. $\$ 1.00$ to $\$ 1.50$.

\section{Euonymous}

Golden Euonymus (Euonymus aurea variegata). A beautiful variety of this popular plant, with leaves variegated green and gold. A very striking plant. 75 cts to $\$ 1.00$.

Evergreen Euonymous (Euonymus Japonica). Leaves dark shining green. A fine plant for the lawn. $75 \mathrm{cts}$. to $\$ 1.00$.

\section{Heather. Calluna}

Famous in literature, beloved of all true Scots, this little evergreen shrub, resembling a dwarf cedar, hardy, vigorous and free flowering is one that should be more generally planted and will be, once it becomes better

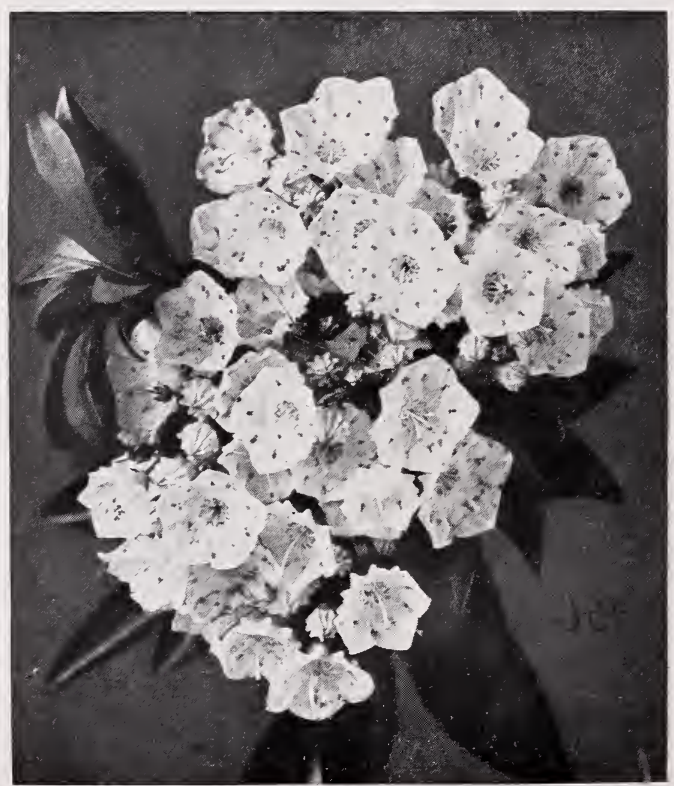

KALMIA OR MOUNTAIN LAUREL. 
known. Fine as a single specimen plant, and very effective in groups or for massing in front of conifers or other tall evergreens.

Scotch Heather (Calluna vulgaris). Low compact shrub-densely leaved. Little pink flowers in abundance. Very handsome and invariably admired. $75 \mathrm{cts}$. to $\$ 1.50$.

White-flowered (Calluna vulgaria alba). Like above, but with white flowers. Makes pleasing contrast when planted with typical variety. $75 \mathrm{cts}$. to $\$ 1.50$.

\section{Holly. Ilex}

English Holly (Ilex aquifolium). A native of England and Continental Europe. Too well known to need description. The hundreds of fine specimens growing in the city of Portland and throughout the $\mathrm{Pa}$ cific Northwest attest to its success and popularity. The crisp, spiny foliage is always bright, and, when loaded with berries, makes it the cynosure of the Christmas landscape. Fine berry-bearing plants from $\$ 1.50$ to $\$ 5.00$. A few specimens usually on hand from $\$ 5.00$ to $\$ 10.00$. Small plants in quantity at low rates per hundred and thousand.

Variegated English Holly (Ilex aquifolium variegatum). A good assortment of these in stock, including gold, silver and other marginal tints. Also hedgehog varieties, carrying spines on the leaves. $\$ 1.50$ to $\$ 5.00$.

Ilex Pyramidalis. A variety of English Holly. Leaves not so sniny, but bears bright red berries in quantity. $\$ 1.50$ to $\$ 5.00$.

\section{Mountain Laurel. Kalmia}

The Mountain Laurel is one of the most ornamental shrubs in cultivation, and its liberal use makes possible some of the most enchanting results. Kalmias thrive in porous or loamy soils, especially those containing leaf-mold or woods-earth. A mulch of forest leaves or pine needles is beneficial, preventing the rapid evaporation of moisture and sudden changes of temperature from

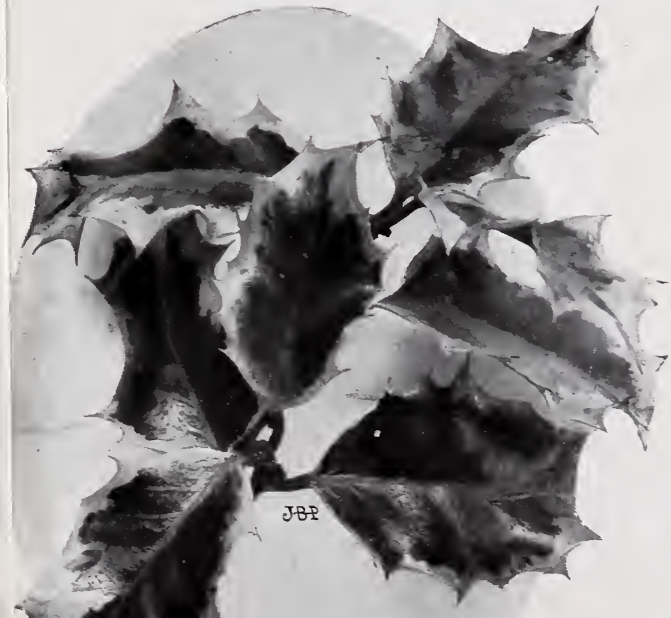

Laurels. Laurus

English, or Cherry Laurel (Laurus Laurocerasus). A small tree, or bush, with handsome shining foliage. Native of Europe. Flowers are white, in numerous, short racemes, expanding in April or May. Justly popular in Europe and destined to be widely planted in the Pacific States. Fine for hedging. $75 \mathrm{cts}$. to $\$ 3.00$. Low price in quantity-see Hedges.

Hardy English Laurel (Laurus Laurocerasus Schipkaensis). A form of the above, noted for its hardiness. This variety is recommended where hardiness is necessary. 75 cts. to $\$ 2.00$.

Laurestinus (Laurus tinus). An evergreen shrub, with dark green shining leaves. Flowers white or tinted with pink, in clusters blooming in winter and early soring. $50 \mathrm{cts}$. to $\$ 2.00$.

Portugal Laurel (Laurus Lusitanica). A small, intricately branched tree, with glossy leaves. Native of Spain and Portugal. Flowers white, disposed in slender racemes, appearing in late spring or early summer. $75 \mathrm{cts}$. to $\$ 2$.

\section{Evergreen. Magnolia}

Southern Magnolia (Mi. grandiflora). A stately, pyramidal tree with short, spreading or ascending branches. Leaves evergreen, thick and firm, bright green and glossy on the upper surface, coated below with rusty hairs. Flowers fragrant, opening in spring and summer, 6 to 8 in. across, pure waxy white. Fruit rusty brown, 3 to 4 in. long: the seeds scarlet. 75 cts. to $\$ 3.00$. See illustration. 


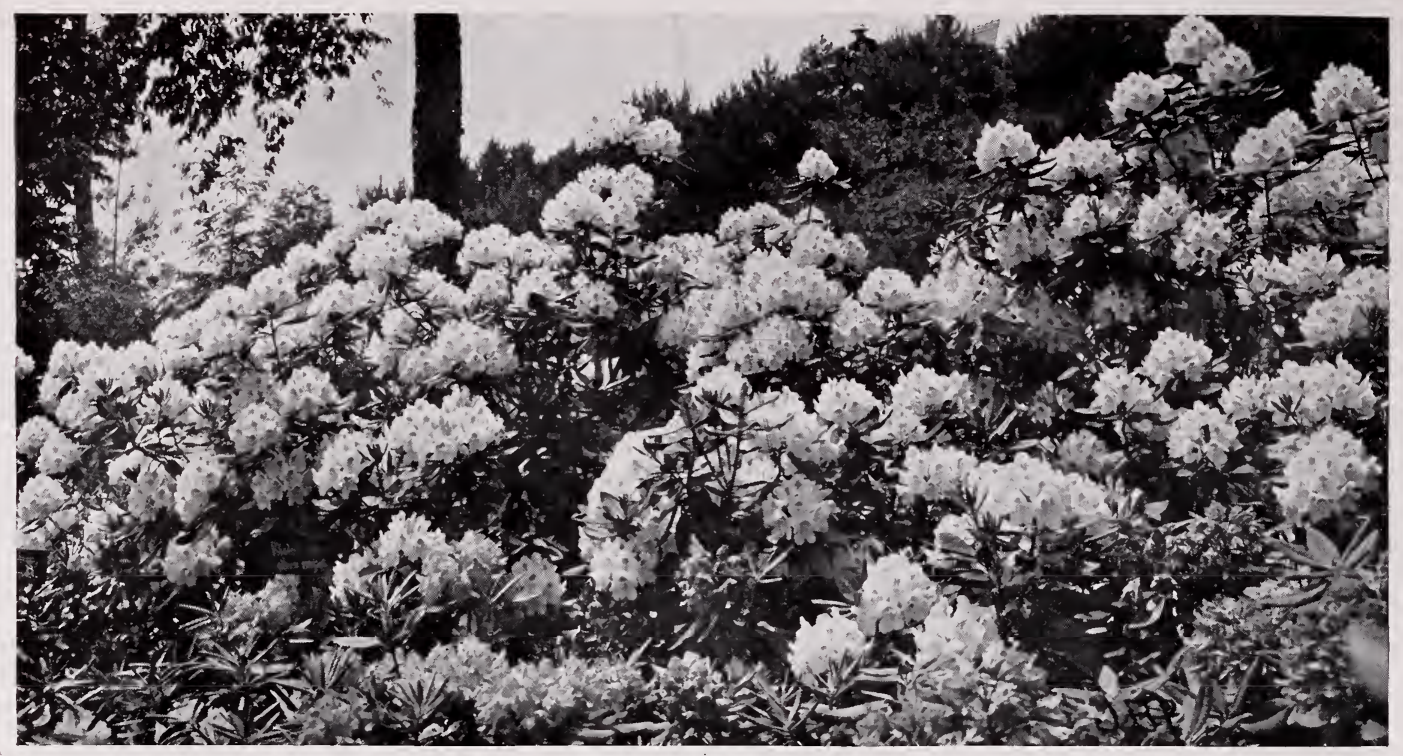

RHODODENDRONS.

\section{Nandina}

Japanese Nandina. A hardy evergreen; compound foliage with numerous small leaflets, rich red at first and dark green at maturity, turning beautiful coppery red in winter. Numerous white flowers in clusters. 50 cts. to $\$ 1.00$.

\section{Oregon Grape. Mahonia}

Oregon Grape, or Mahonia (Berberis aquifolium-Mahonia aquifolium). Oregon State Flower. A handsome ornamental shrub, with dark, lustrous green, spiny toothed leaves, in dense clusters, appearing in spring. Berries blue or nearly black. Distributed naturally from British Columbia to Oregon. Fine as single specimen, or in groups, and becoming deservedly popular as hedge or border. Nursery-grown, 50 cts. to $\$ 1.00$. Low prices in quantity. See Hedge Plants.

Mahonia Japonica (Berberis Japonica). Japanese Mahonia. Leaves large, bright, shining green and yellow. Flowers yellow, in long racemes, opening in early spring. Bluish-black, with a bloom. $50 \mathrm{cts}$.

\section{Pittisporum}

Pittisporum Tobira. Japanese origin, semi-hardy, winter flowering plant that is splendid as a single specimen. Leaves dark green in clusters at ends of branches, with short heavy clusters of fragrant white flowers. $\$ 1.00$ to $\$ 1.50$.

\section{Rhododendrons}

These, the showiest of all evergreen shrubs, find a congenial home in the Pacific Northwest. The native sorts are to be found in the mountains and along the coast of Oregon and Washington, and the latter State has wisely named the Rhododendron its State flower. They require good, rich, deep soil, and a somewhat shaded location for fine foliage, but open locations produce more and better flowers. Their handsome foliage and showy flowers make possible some of the most beautiful results and interest that cannot be obtained by any other plants. They succeed admirably when planted alone, but for magnificent effects, mass plant- ing is desirable. (See front cover). and satisfactory

Rich, purplish-crimson.

Cynthia. Bright red.

Fastuosum flora plena. Lavender, double flower.

Purpureum elegans. Fine purple.

Roseum elegans. Fine rose.

Anry Havelock. Fine scarlet.

Mad. Masson. Pure white, yellow throated. et wither-buds, $\$ 1.50$ to $\$ 3.00$ each; $\$ 15.00$ to $\$ 30.00$ per dozen.

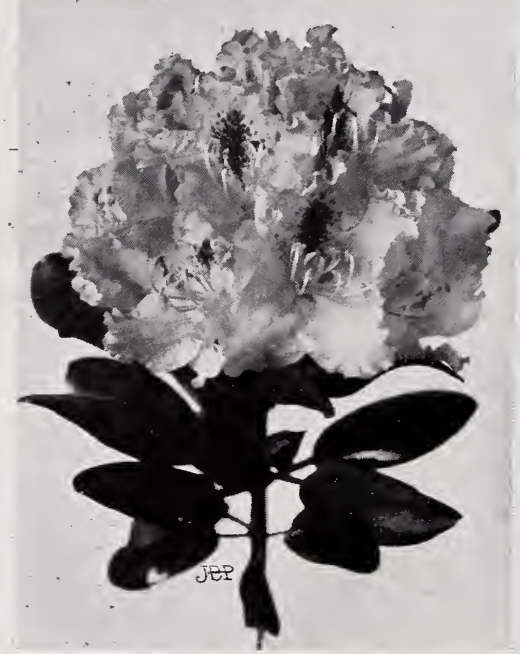

RHODODENDRON FLOWER. 


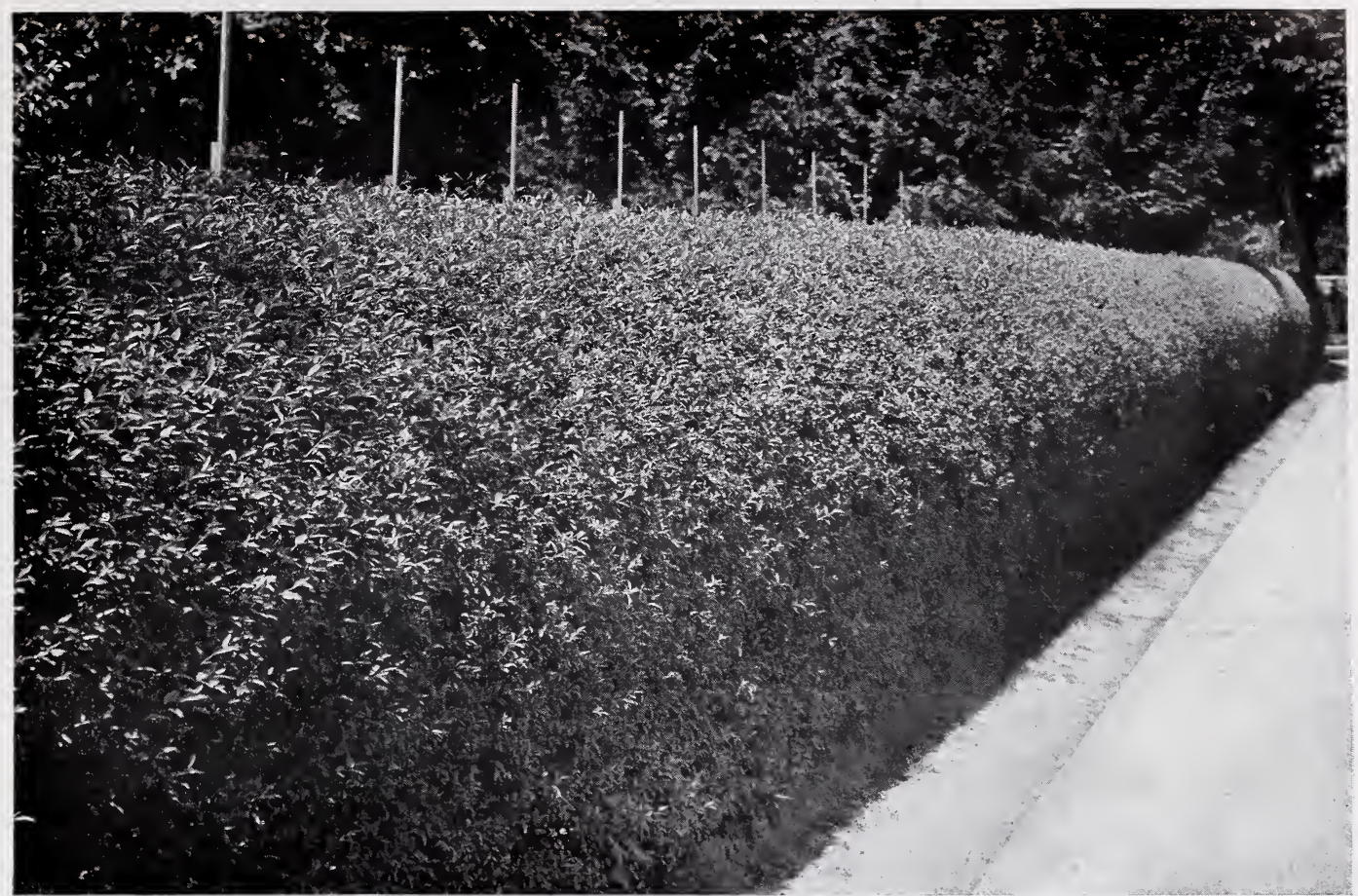

PRIVET HEDGE. 19th Street between Lovejoy and Marshall, Portland.

\section{Hedges-Live Fences}

The garden craftsman, if he is a true artist, will let nature make his fences. Old dead walls and stiff fences are becoming obsolete among people of good taste. Anyone who has seen a rightly kept hedge of Privet, Japanese Quince, English Laurel, Oregon Grape, English Hawthorn. Holly, or Roses, knows what an important feature it is in making truly beautiful grounds. Low growing hedges-useful and ornamental-can be made of a number of plants; while by using other plants, high hedges that will serve as wind breaks, screens to hide unsightly objects and sun-shields can be had. Such hedges not only keep out prying eyes, cold winds, snowdrifts, etc., but shut in warmth and beauty, protect the children's playgrounds winter and summer, and shelter plants that would otherwise require winter protection or summer shading, giving earlier flowers and fruits.

The shape of the hedge is important, the round-top or conical, being best as a rule; as trimming in this way the growth of the lower branches is favored, keeping the wall of green solid and even from top to bottom. A flat top hedge holds the snow which might spread and break the branches, and the straight sided and flat top hedges are more apt to become ragged and open at the base than those trained in conical or rounded form, narrowing to a pointed top.

For medium size formal hedge the Privet is probably the most satisfactory: a good grower, responds readily to the pruning knife: is practically an evergreen with us, rerfectly hardv, and most economical in cost. English Laurel. Japanese Quince and Lawson's Cypress are also fine for formal sheared hedges. For the high hedge, Norway Spruce, Lawson Cypress and the Hem- locks are all desirable; the Norway Spruce, especially, being sturdy, fast growing and very handsome.

For the untrimmed hedges, those allowed to grow naturally, with but little or no pruning, and which in many localities are now a favorite means of enclosing flower and vegetable gardens, edging terraces and defining roads and walks, covering unsightly defensive barb wire or picket fences, nearly any free growing shrub can be used, such as Spirea Thunbergii, Purple Barberry, English Hollv, Oregon Grape, Roses, Deutzias, and numerous others.

Where ordinary hybrid and other roses are not hardv or cannot be planted, the Japanese Rosa Rugosa is a favorite, as it is perfectly hardy and beautiful anywhere and at all seasons. Its handsome foliage is almost evergreen, a continuous bloom of large single flowers during summer with clusters of red berries hanging on during winter months. It thrives even at the seaside, where other things die quickly.

\section{Hedge Plants}

Barberry, Purple. 18 inches. $\$ 6.00$ per 100

Hawthorn, English. Single white, 2 to 3 feet. $\$ 6.00$ per 100 . Low prices in 1,000 lots.

Japanese Ouince. $1 \mathrm{I} / 2$ to 2 feet. $\$ 10.00$ per 100 .

Laurel, English. 1 to $1 \mathrm{I} / 2$ feet. $\$ 25.00$ to $\$ 30.00$ per 100 . See illustration.

Lawson's Cypress. 10 to 12 in. $\$ 10.00$ per 100 .

Norway Spruce. Nursery grown. $\$ 20.00$ to $\$ 30.00$ ver 100 .

Oregon Grape. Nursery-grown. \$20.00 to $\$ 30.00$ per 100 . See illustration.

Privet, European. $\$ 2.50$ to $\$ 4.00$ per 100 . See illustration.

Spirea, Thunberg's. Fine for borders. $\$ 10$ pr 100.

English Hollv. Can be supplied in small sizes at from $\$ 10.00$ to $\$ 25.00$ Der 100 .

Rosa Rugosa. 2 yr., 2 ft. up. $\$ 15.00$ per 100. 


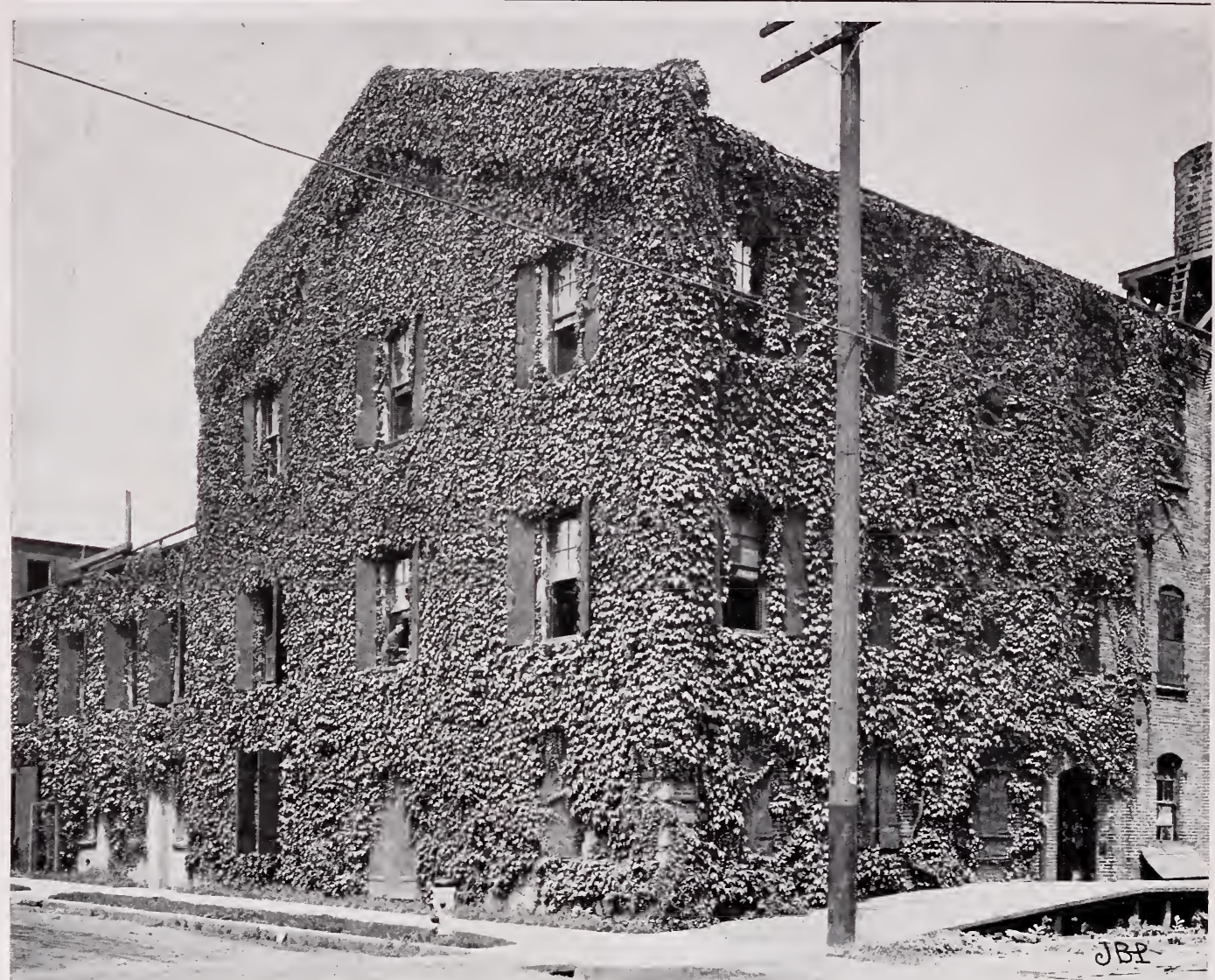

BOSTON IVY FOR COVERING FACTORY. Portland Cordage Co., 13th \& Marshall Sts., Portland.

\section{Hardy Vines and Creepers}

The need of Vines and Creepers for home embellishment is well known as nothing adds more grace and beauty to the exterior of the house than well placed and appropriate Vines. They cover porches and pergolas, giving shade, comfort, perfume and flowers. Also invaluable for converting offensive looking fences or other unsightly features into things of beauty. Churches, depots, factories, out-buildings, and all brick and stone edifices can be covered by clinging vines without trellis work, that will relieve their harshness or lack of architectural beauty a nd make them things of beauty and joys forever.

\section{Actinidia}

Silver Vine (Actinidia Arguta). A strong growing vine with dark lustrous. heart-shaped leaves, well adapted for training against nillars and for covering arbors and trellises. White flowers in clusters in early summer. Yellow berries. 75 cts. to $\$ 1.00$.

\section{Akebia}

Akebia Quinata. Five-leaved, ornamental Japanese Climber; hardy; racemes of rosypurple flowers in 1 a te spring. Thrives best in moist loamy soil with sunny exposure. 75 cts.

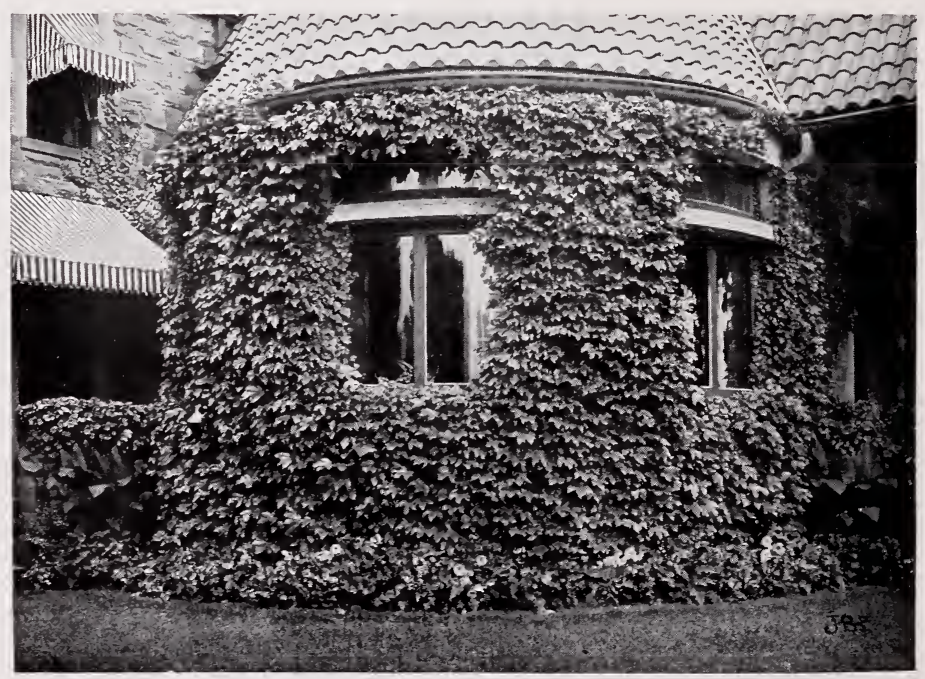




\section{American Ivy. Ampelopsis}

Virginia Creeper, or American Ivy (Ampelopsis quinquefolia). The five-lobed leaves turn a bright red in autumn. A valuable climber. 35 to $50 \mathrm{cts}$.

Boston, or Japanese Ivy (Ampelopsis Veitchii; syn., tricuspidata). The tendrils hold tenaciously to any support and the roots find nourishment in the poorest soils. It is quite hardy and a rapid grower. The leaves are strung thickly and overlap one another in a mat of fresh shining green that turns a brilliant red in autumn. It is the most popular Ivy for the covering of buildings and walls, and grows well in the smoky atmosphere of cities. 35 to 50 cts. See ills.

Purple-leaved (Ampelopsis Veitchii purpurea). A new form of the above, with purple foliage. A very fine variety. 50 to $75 \mathrm{cts}$.

\section{Bittersweet. Celastrus}

Celastrus Scandens. Also known as Staff Vine. A very vigorous grower. Its scarlet fruit, adherent nearly all winter, is an object of much beauty. $50 \mathrm{cts}$.

\section{Clematis}

Clematis, Duchess of Edinburg. Vigorous habit and free bloomer. Double white flower. $75 \mathrm{cts}$.

Clematis, Henryi. The finest of all large white flowering. 75 cts.

Clematis, Jackmani. The most popular variety. Large, velvety, dark purple flower. See illustration. 75 cts.

Clematis, Madame Eduard Andre. New single crimson flower of good size and borne in great profusion. $75 \mathrm{cts}$.

Clematis, Paniculata. From Japan. Panicles of small, pure white, fragra n t flowers

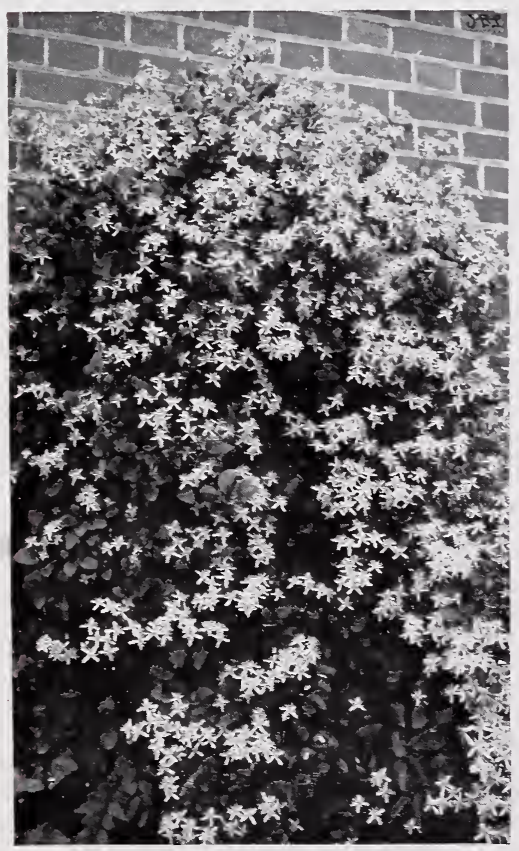

OLEMATIS PANICULATA

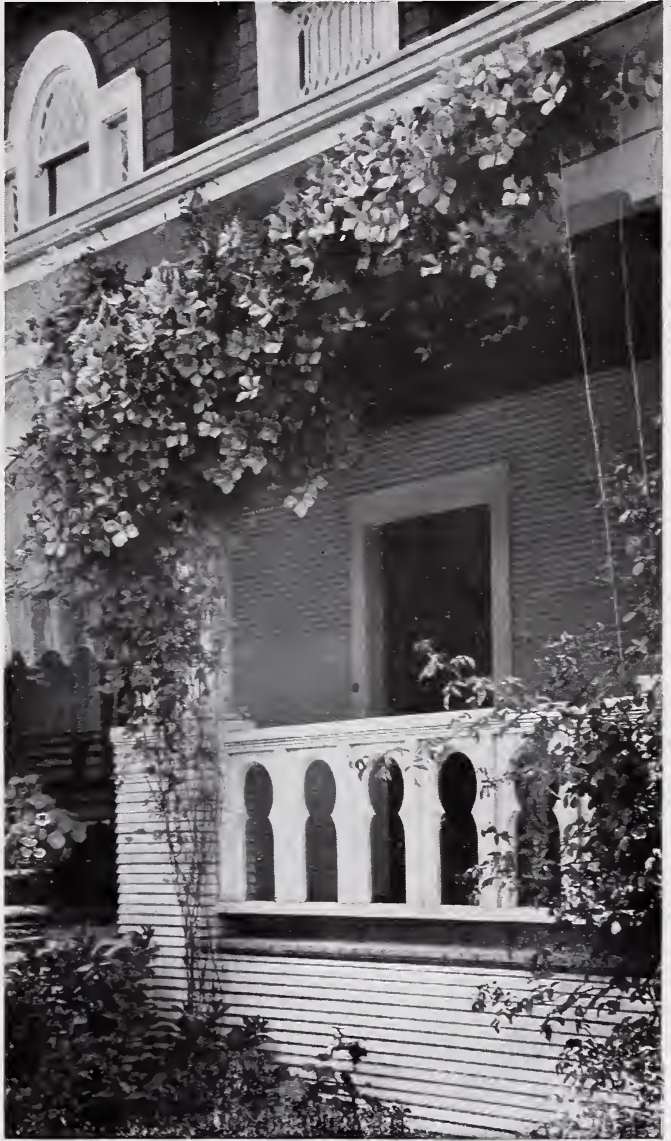

CLEMATIS JACKMANII.

Residence W. Merriman, 304 E. 16, North

borne in great profusion. Very desirable and entirely hardy. Blooms in late summer. See illustration. $50 \mathrm{cts}$.

Clematis, Ramona. A very large, single-flowering lavender. 75 cts.

Clematis, Montana. A Mountain Clematis from the Himalayas. Vigorous grower, clusters of sweet-scented, Anemone-like, white flowers in late spring. Novelty. $75 \mathrm{cts}$.

\section{Dutchman's Pipe. Aristolochia}

Dutchman's Pipe (Aristolochia Sipho). A strong, rapidgrowing, tropical-looking vine, with handsome, light green leaves, 8 to 12 inches across. It will give a quick, dense shade, and is much used on arbors and trellises. The corrolla of the brown flowers is shaped like the bowl of a pipe. $75 \mathrm{cts}$. to $\$ 1.00$.

\section{English Ivy}

English Ivy (Hedera Hibernica). Leaves a dark, shiny green. Used in England for covering old trees, etc. A very close-growing variety. 25 to $50 \mathrm{cts}$.

Variegated Ivy (Hedera Maderiensis). A white variegated variety. $50 \mathrm{cts}$.

\section{Honeysuckle. Lonicera}

Monthly Fragrant, or Dutch Honeysuckle (Lonicera Belgica). Red and yellow, fragrant, with handsome flowers. 25 to 50 cts. 


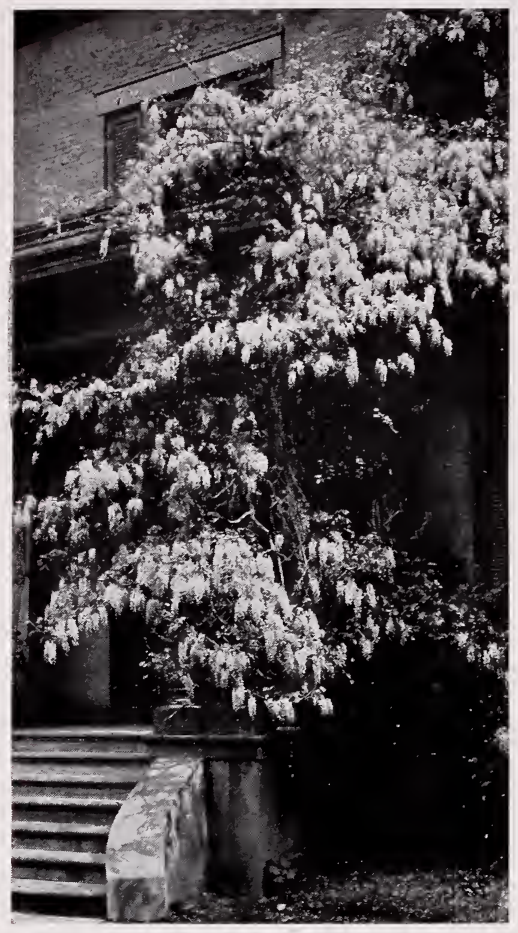

WISTARIA.

\section{Polygonum Baldschuanicum}

A new climber, introduced recently by a famous French nursery where I saw it and obtained a stock. Vigorous and hardy, clinging well to walls, tree trunks, porches or trellises, decorative and handsome. Resists sea breezes well. White flowers in panicles-fine for decorative purposes-continuous from May to October. Rare. Strong plants, $\$ 1.50$.

\section{Silk Vine. Periploca}

Silk Vine (Periploca Græca). Stems twining, 20 to 30 feet long, clothed with numerous dark and glossy leaves of broadly lanceolot outline. Flowers brownishpurple inside, the margins and reverse side greenish, an inch or more across, borne in loose long-stemmed cymes. 50 cts.

\section{Trumpet Vine. Tecoma}

Trumpet Vine (Tecoma grandiflora). The orange-red flowers are larger and earlier than $\mathrm{T}$. Radicans, and it is a more bushy grower. Leaves compound, consisting of 7 to 9 ovate, bright green leaflets, which persist until killed by frost. Needs protection in cold climates. 50 cts.

The Scarlet Trumpet Flower (Tecoma radicans, or Bignonia radicans). Long and handsome dark green foliage and quite showy clusters of orange and scarlet flowers during the summer. 50 cts.

Cross Vine (Tecoma, or Bignonia Capreolata). A strong vine, climbing to great heights. Handsome climber for outside use and covering walls. Flowers yellowish-red. 75 cts.

Hall's Japan Evergreen Honeysuckle (Lonicera Halleana). One of the most popular and valuable of all. Blooms perpetually from July to December, and covered with a profusion of fragrant white and yellow flowers; rich, dark green foliage, which remains on most of the winter. 35 to 50 cts.

\section{Jasmine. Jasminum :}

Yellow Jasmine (Jasminum nudiflorum). A high-twining vine with dark green persistent leaves and fragrant golden flowers. 50 cts.

White Jasmine (Jasminum officinalis). Very fragrant white flowers. 50 cts.

\section{Kudzu Vine. Pueraria}

Pueraria Thunbergiana. A hardy and remarkably vigorous vine of Japanese origin, often growing 40 feet in single season. Fine for covering large areas. Large, bright green leaves; flowers pea-shaped, purple, in racemes from old stems appearing in late summer. $75 \mathrm{cts}$.

\section{Periwinkle or Myrtle. Vinca}

Vinca minor coerulea. Green foliage, strong grower. flowers blue.

Var. alba. A form of the above, with pure white flowers, and a most useful and attractive plant.

Var. rosea plena. A rare form with double, rose-colored flowers.

Var. variegata. Variegated leaves.

Any of above, 15 cts. each; $\$ 1.00$ per dozen.

\section{Wistaria}

Chinese Wistaria (Wistaria Chinensis). A rapid-growing tall vine with handsome foliage and flowers. Native of China. Leaves compound, consisting of about eleven pale green leaflets. Flowers pea-shaped, purplish, profusely borne in dense drooping clusters 7 to 12 inches long, opening in midspring. Very showy and desirable. $50 \mathrm{cts}$.

Chinese White Wistaria (var. alba). A form of the above with pure white flowers. 75 cts.

Japanese Wistaria (var. multijuga). A vigorous tall growing vine with bright green foliage, widely cultivated in Japan and long supposed to be a native of that country, but probably of Chinese origin. Leaves compound, consisiting of 17 to 21 leaflets. Flowers light purple, in loose drooping racemes 1 to 3 feet long. A remarkably distinct and showy species. The long clusters of flowers are very effective for pergola work, the immense racemes producing most stunning effects. Fine grafted specimens that will bloom first season, $\$ 1.00$; extra specimens, $\$ 3.00$.

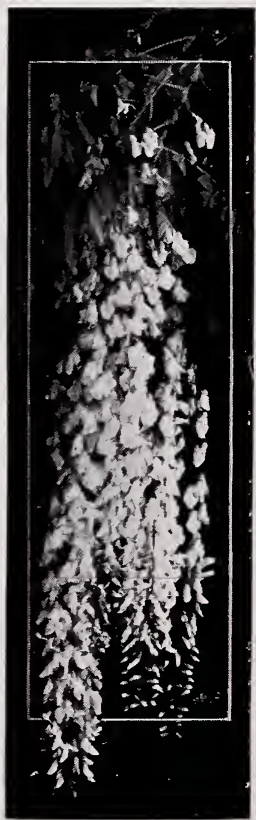

WISTARIA FLOWERS. 


\section{Ornamental Grasses and Bamboos}

Because cataloged as "Grasses" many are apt to lightly pass over this important group of plants, valuable in gardening of the right sort. Their showiness, inimitable grace of motion, cool silvery neutral tints, are restful to the eye and add beauty and harmony to the landscape. If you wish something easy and unusual in garden features, grow some of this group.

\section{Adam's Needle. Yucca}

Adam's Needle (Yucca filamentosa-Spanish Bayonet). Tery odd and beautiful, long spear-like evergreen foliage and magnificent spikes, or pyramids, of waxy, drooping, creamy-white bell-shaped flowers. Fine for rockeries, in groups on lawn, in front of shrubbery and for borders. 50 cts. to $\$ 1.00$.

\section{Bamboos}

Tall Chinese Cane (Arundinaria Simoni). This, the tallest of the Canes, frequently reaches a height of 12 to 20 feet. Native of China. Leaves 8 to 12 inches long, about an inch wide, rich, lustrous green, the apex very long and slender. Clumps, 75 cts.

Golden Bamboo (Phyllostachys aurea). A graceful species with numerous yellowish stems 10 to 15 feet tall. Leaves soft green, spreading or drooping from the numerous dainty branches. One of the hardiest of its genus. Clumps, 75 cts.

Tall Bamboo (Phyllostachys mitis). A tall species, with wand-like arching stems 15 to 20 feet tall, or eren more in favorable situations. Leaves light green, gracefully dis-
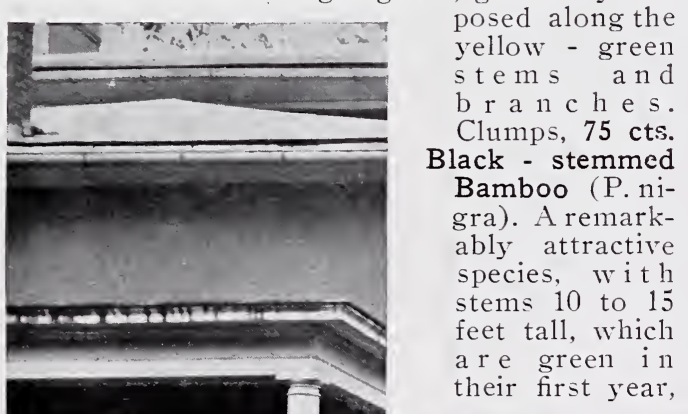
Bamboo (P. nigra). A remarkably attractive species, wit h stems 10 to 15 feet tall, which a $r$ e green in their first year,

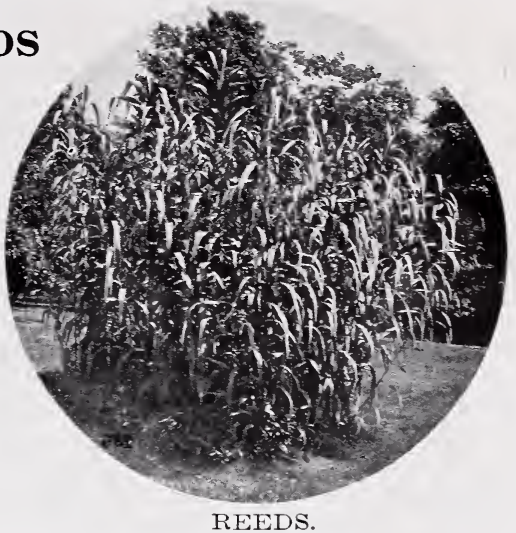

but change to black during the second year. Clumps, 75 cts.

\section{Eulalia}

Narrow-leaved (E. gracillima univittata). A beautiful hardy grass, densely tufted,3 to 6 ft. tall, numerous narrow drooping leaves. Flowers in panicles toward end of season. Clumps, 75 cts.

\section{Giant Reed. Arundo}

Giant Reed (Arundo Donax). A hardy, vigorous perennial, attaining a height of 10 to 15 feet. Native of Europe and Asia. Leaves very long and broad, glaucous green, produced from the base almost to the top of the stems. Plumes reddish-brown, changing to silvery gray, a foot or more in length, long persistent, quite showy. Clumps, 75 cts.

\section{Pampas. Gynerium}

Pampas Grass (Gynerium argenteum). Stems 5 to 8 feet tall. forming a dense clump. Leaves long and narrow, chiefly from the base, gracefully spreading and drooping. Plumes silvery white, very showy, sometimes 2 feet or more in length. Clumps. $75 \mathrm{cts}$.

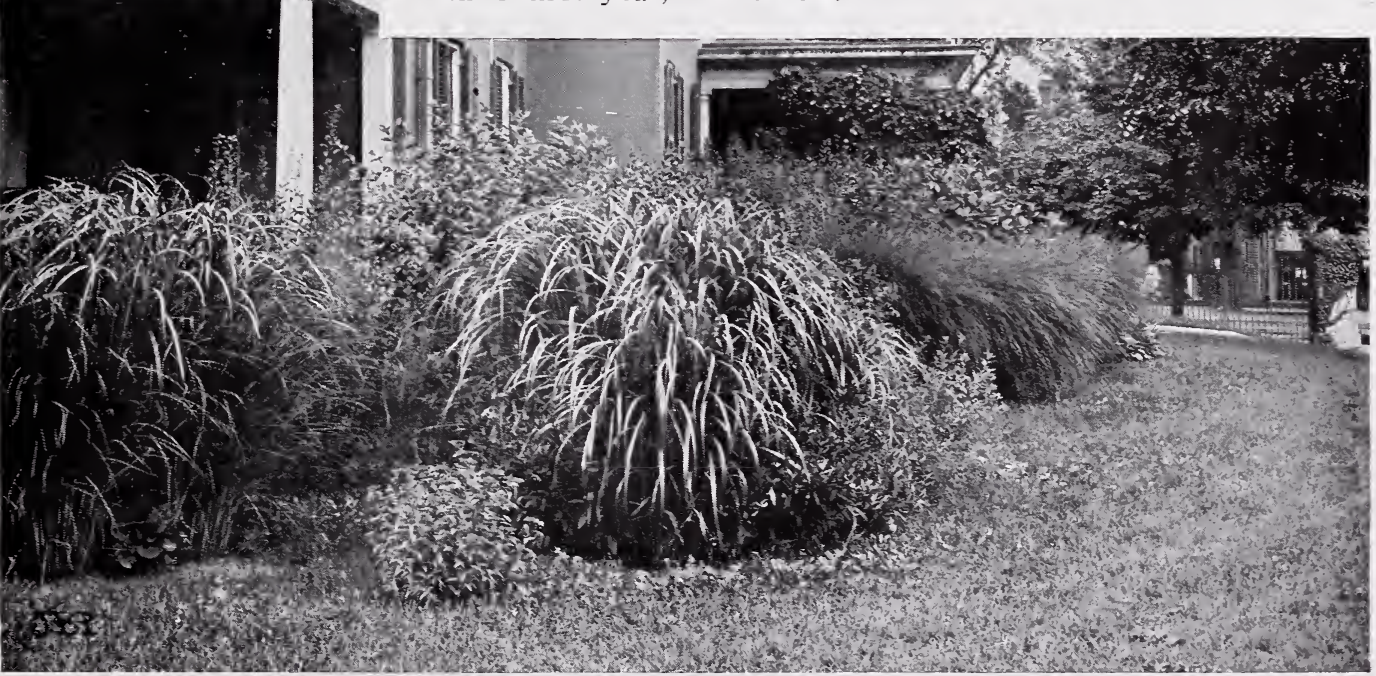

ORNAMENTAL GRASSES 


\section{Peony. Paeonia}

The coming flower. Absolutely hardy, having no insect pests, and ever increasing in size and beauty. The flowers are large and of great brilliancy of color, ranging from pure white and pale blush shades to the deep crimson. Magnificent for cut-flowers. The foliage is ornamental, the autumu coloring being very fine.

This nursery has thousands of plants, strong and thrifty, and does not send out the microscopic specimens frequently sent to the West from Eastern nurseries. Over sixty varieties undergoing trial in addition to the following, which are recommended. See back cover and illustrations.

Plants that will produce flowers first season, from 35 to 75 cts. each; $\$ 4.00$ to $\$ 3.00$ per dozen; extra plants, $\$ 1$, $\$ 1.50$ and $\$ 2$ each.

Alba plena. A fine, pure white.

Baron James de Rothschild. Silvery rose.

Cytharee. Flesh, to white

Delachei. Deep purplish, crimson.

Doyen d'Enghien. Dark violet-rose.

Faust. Soft lilaceous fleshcolor.

Festiva maxima. Enormous, very full, shell-formed Bloom often 7 to 8 in. in diameter on strong $3 \mathrm{r} / 2 \mathrm{ft}$. st e m s ; color snow-white, shading to delicate creamy-white at base of petals, with an occasional clear purple spot on edges of center petals; very fragrant. Undoubtedly the finest early white in existence. Special, 75 cts. to $\$ 2.00$.

Isabelle Karlitsky. Satiny rose.

Jeanne d'Arc. Large, soft pink, sulphur-white center. One of the best varieties in cultivation.

Lais. Light rose, sulphuryellow center.

Mad. Breon. Rosy flesh, with yellow center.

Mad. de Verneville. Flesh color with carmine spots, edge of broad light rose petals.

Magnifica. Pink.

Pottsi rosea alba. Pink, with white center.

Princess Galitzin. S of t flesh, to sulphur-white.

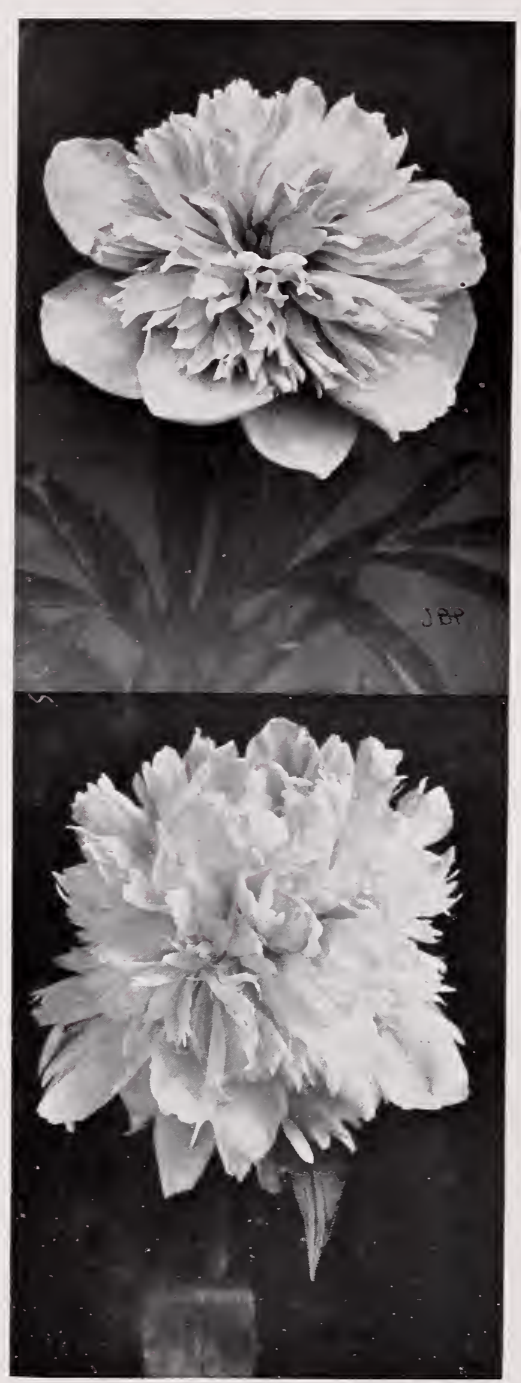

PEONIES
Reine des Roses. Lilac rose, center light rose with yellow.

Rosea elegans. Soft pink, with light center.

Thyrne. Yellowish-white.

Zoe Calot. Tender rose, shaded with lilac.

\section{Daisy. Shasta}

Shasta Daisy (Chrysanthemum leucanthemum Shasta). Large white flowers, very showy, blooming throughout the summer. A beautiful, hardy perennial that ought to be in every garden. Strong plants, 25 cts. each; $\$ 2.50$ per dozen.

\section{Lilies}

The beauty of the Lilies appeals to every one. A really beautiful garden without them is unimaginable; they are needed in quantity and variety to complete it,-among the Rhododendrons, against the evergreens of formal gardens, in groups or lines in the shrubbery or borders, wherever serene, stately, faultless beauty of outline is required. I have not catalogued the Lilies heretofore, but have grown them in the nursery for a number of years, supplying a limited number of patrons who demand very best quality. I import only a few varieties from Japan, only one grade, but these of largest size and highest quality. I list only a few that every good garden really needs, but other fine sorts can be suoplied on request when filling out orders for these.

Autumn is by far the best time to plant all the hardy Lilies, and their culture is simple. Give them good, well drained soil, with no fresh manures in it, a cushion of sharp sand about their roots, and a mulch in winter, with no disturbance of the roots for at least several years. Planted in groups of three to six or more of a kind the effect is much better than when planted singly. Plant deeply, 8 inches is good, unless bulbs are very small, for Lilies, a $s$ a rule, are not set deep enough and therefore fail in a few seasons.

Queen's Perfection. Fesh-white; very free- Nammoth size bulbs, 25 cts. each; $\$ 2.50$ per flowering.

Queen Victoria. Fesh-white. dozen.

Gold Banded (Lilium Auratum). The finest 


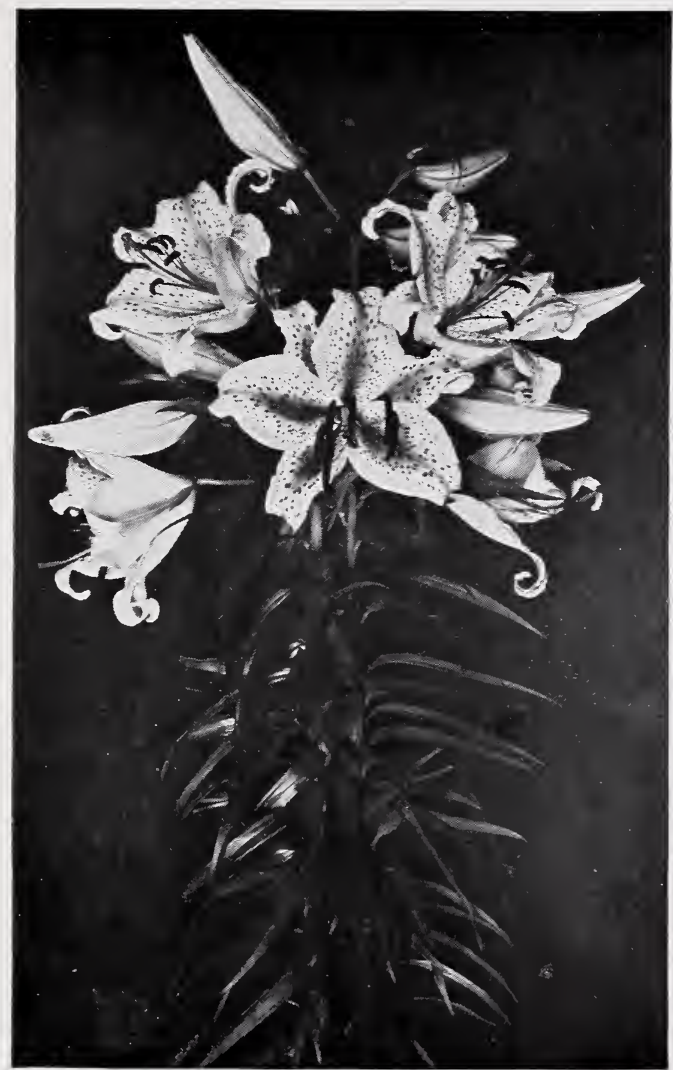

GOLD BANDED LILY (See page 34)

are stronger and less liable to disease, hence generally preferred. They can be used for Easter forcing, but bloom naturally in the garden during summer. Beautiful pure white, trumpet-shaped flowers, very fragrant.

Tiger Lilies (Lilium Tigrinum). Hardy, robust, permanent old sort that lives on in the old gardens from year to year, making large clumps with an abundance of large flowers, orange-salmon color with black spots. Fine for planting among shrubbery.

Mt. Hood Lily (Lilium Washingtonianum). A beautiful lily, white with pinkish tinge, stems 3 to 4 feet long, giving a number of handsome fragrant flowers. Native of Oregon.

\section{Japan Iris. Iris Kaempferi}

The Japanese species are the finest of the hardy Irises. Flowers are very large, in various tints of purple, lavender, blue, white and other light shades, many of them veined with darker rich colors, making most effective combinations. A sunny situation in moist, rich loam is best adapted to their requirements, and as the clumps increase in size, liberal enriching of the ground, or even replanting, is attended by a great gain in the size and number of the flowers. I have a superb collection and offer strong clumps, not small, divided roots, that will flower first season, at 50 cts. each; $\$ 5.00$ per dozen.

Send list of wants in fine colors. The Japanese names are unpronounceable and it will be necessary to Americanize them in order to standardize varietie.

of all Lilies when well grown from good bulbs. Great flowers of ivory-white and gold flecked with crimson dots and delightfully fragrant, crowd the stout stems. See illustration.

Japanese Recurved-Pure White (Lilium Speciosum album).

Japanese Recurved-Deep Pink Spotted (Lilium Speciosum rubrum). Two of the hardiest and most satisfactory varieties, graceful with dainty waxen flowers with a heavy glittering fringe as a corona for the center. Profuse bloomers, and last for days when cut and put in water.

Hardy Bermuda (Lilium Longiflorum Giganteum). Large sized.

Hardy Bermuda (Lilium Longiflorum Multiflorum). Many flowered. These two varieties are similar to the well-known Easter Lily, but
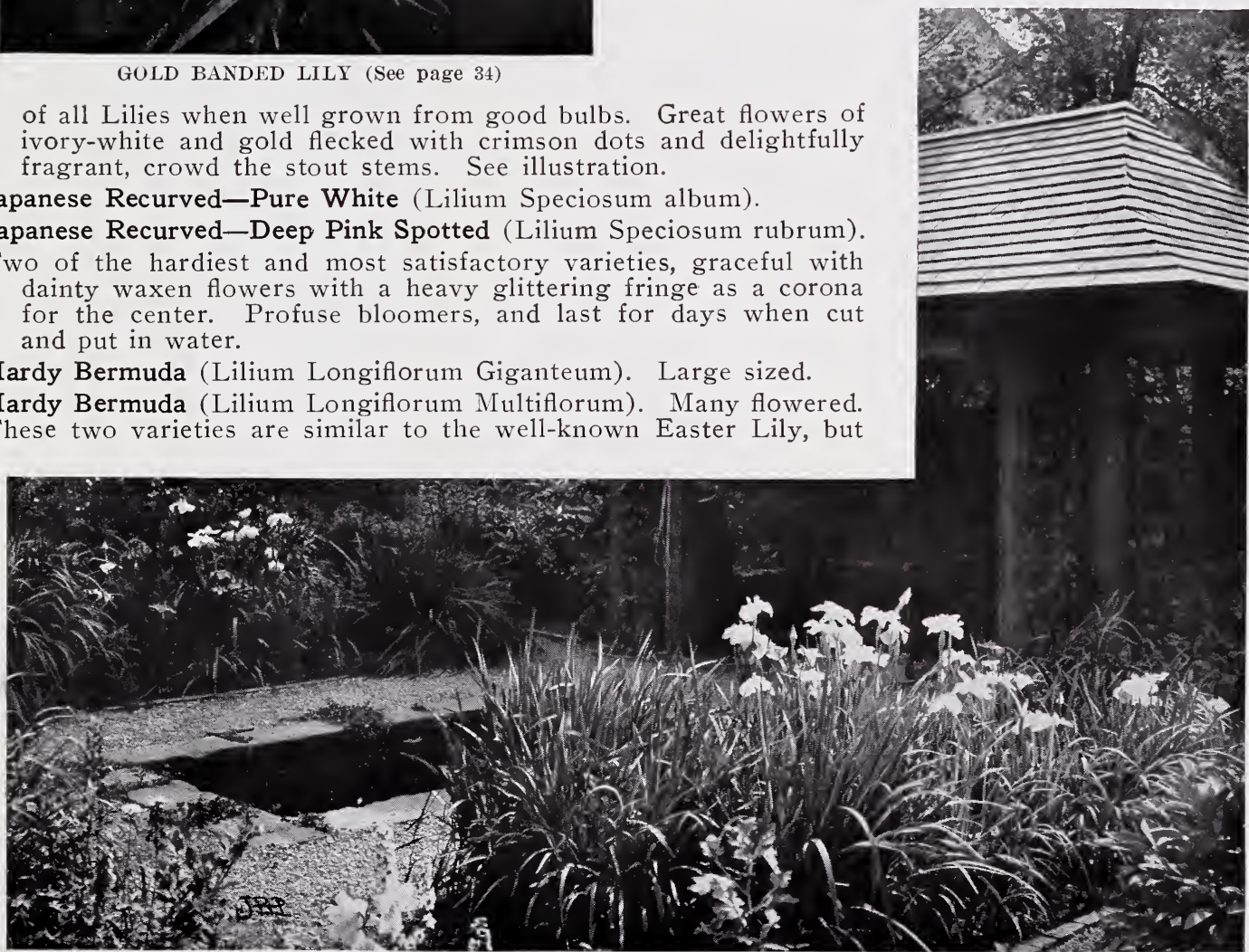


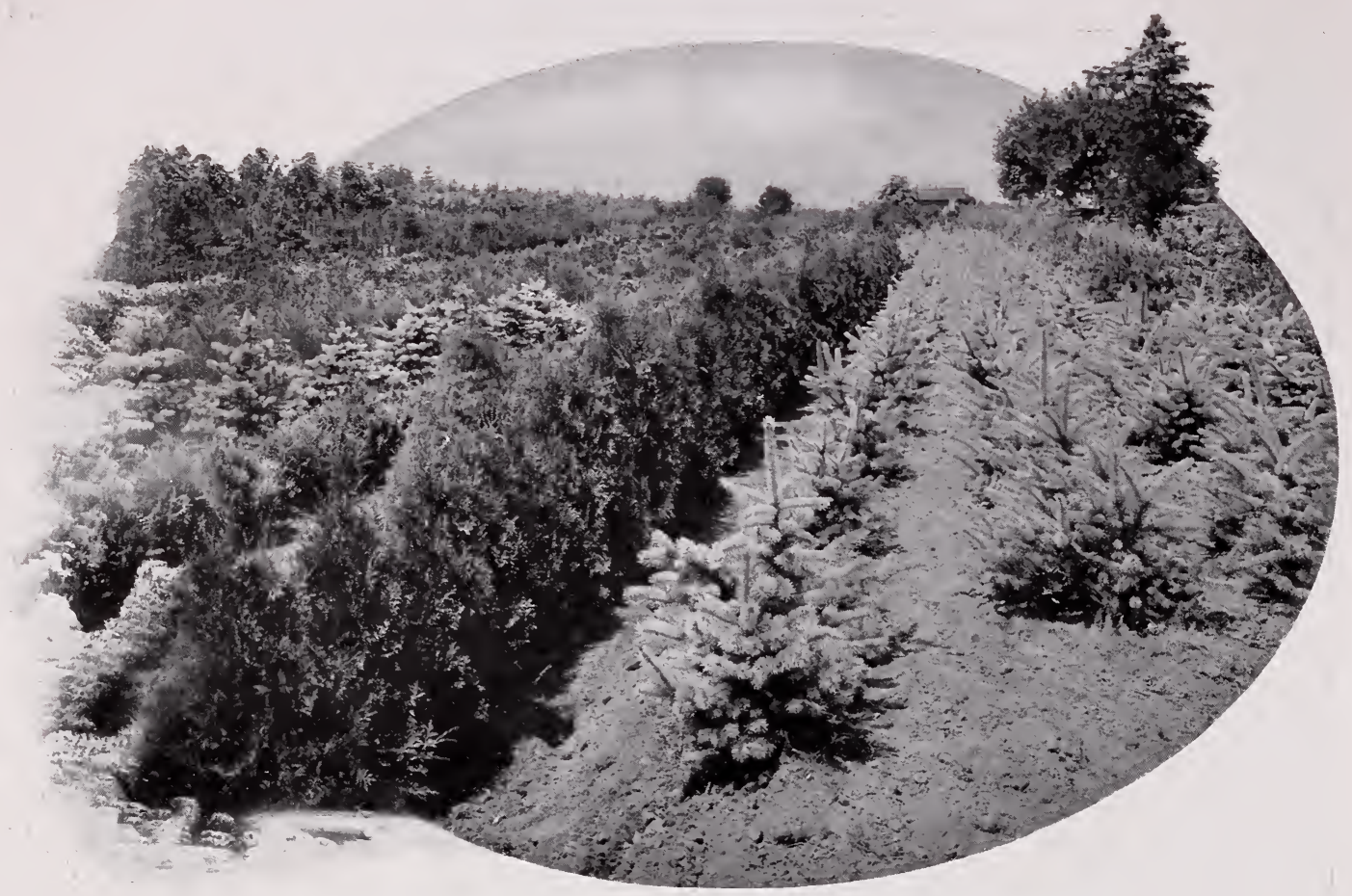

NURSERY VIEW, COLORADO BLUE SPRUCES AND O'THER CONIFERS

\section{Conifers, Evergreens}

The Pacific Coast is rich in its Conifers. Probably no section is more favored in regard to the size, variety and quality of its evergreen trees. Climatic conditions are responsible for this; therefore, it is no wonder that varieties brought from other localities likewise flourish.

Transplanting of evergreens is necessary as long as they remain in the nursery, in order to promote the growth of fibrous roots; and no stock sent out has rested more than two years in one place. This frequent transplanting is expensive and figures in the cost of largesized trees, but it insures success of stock growing after being planted in its permanent location.

\section{Arbor Vitae. Thuya}

Py ramidal Arborvitae (Thuya py a midalis). A most valuable upright evergreen, of dense, compact habit. Foliage light green. Naturally pyra midal growth, rapid grower and hardy. Fine specimens, 3 to 4 feet, $\$ 3.00$.

Golden Oriental Arborvitae (Thuya orientalis elegantissima). A low, compact shrub, in which the foliage assumes a beautiful gold-yellow color at the beginning of the growin season. 75 cts. to $\$ 2.50$.

Thuya Japonica filiformis. A $n$ e w Japanese variety, with thread-like foliage; compact habit. We consider this one of the most distinct and desirable novelties, and it is becoming a great favorite. $\$ 1.00$ to $\$ 2.50$.

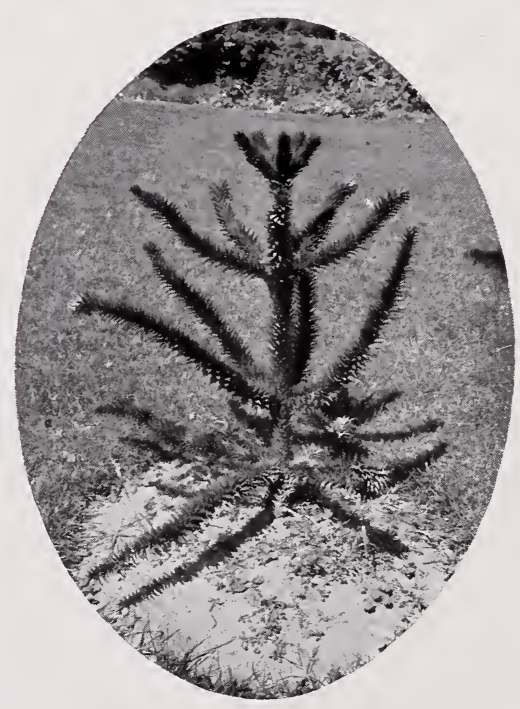

CHILI PINE (See page 37)

\section{Cedar. Cedrus}

Mt. Atlas Cedar (Cedrus Atlantica): Of vigorous growth, pyramidal form; dense, light silvery foliage, very thick on the upper side of the branches. Hardy and valuable. One of the finest evergreens; $\$ 1.00$ to $\$ 2.00$; extra specimens, $\$ 3.00$ to $\$ 5.00$.

Cedrus Atlantica var. glauca. One of the most beautiful evergreens yet sent out. Upright growth, but lowbranched and of compact habit, with solid foliage entirely covering the branches. Leaves very fine and of a delicate steel-blue tint, equal to the finest of the glaucous Colorado Blue Spruces. A great acquisition to the list of choice conifers. Very rare. $\$ 1.00$ to $\$ 3.00$; specimens, $\$ 5.00$ to $\$ 10.00$. 
Himalaya, or Indian Cedar (Cedrus Deodora). Of vigorous growth, pyramidal form; graceful foliage of a light silvery or glaucous green. One of the most beautiful of evergreens. $\$ 1.00$ to $\$ 3.00$; extra specimens, prices on application. See illustration.

Cedrus Deodora var. glauca. A fine novelty, beautiful foliage and habit of the species, but leaves of the Glauca variety are richly tinted with bluish-white. $\$ 1.50$ to $\$ 5.00$.

Cedrus Deodora var. pendula. A weeping form of Deodora. $\$ 2.50$ to $\$ 5.00$.

Cedar of Lebanon (Cedrus Libani). Vigorous, spreading branches, with large, dark green foliage. Very choice and rare. $\$ 1.00$ to $\$ 3.00$.

\section{Chili Pine. Araucaria}

Chili Pine, Monkey Puzzle (Araucaria imbricata.) A distinct and remarkable tree, strangly imposing as an isolated specimen and extremely impressive and effective when planted in avenues. Native of the western slope of the Chilean Andes. Leaves broadly lanceolate, rigid and bristling, bright shining green, densely clothing the branches. $\$ 1.00$ to $\$ 2.50$; specimens, $\$ 4.00$.

\section{Cypress or Port Orford Cedar. Cupressus}

Lawson's Cypress (Cupressus Lawsoniana). A handsome tree of graceful habit, delicate, feathery, bluish-green foliage. A native of the coast region of southern Oregon and northern California. $75 \mathrm{cts}$. to $\$ 2.00$.

Erect Lawson's Cypress (var. erecta viridis). A fine, upright grower. Soft green and stately. $\$ 1.50$ to $\$ 3.00$.

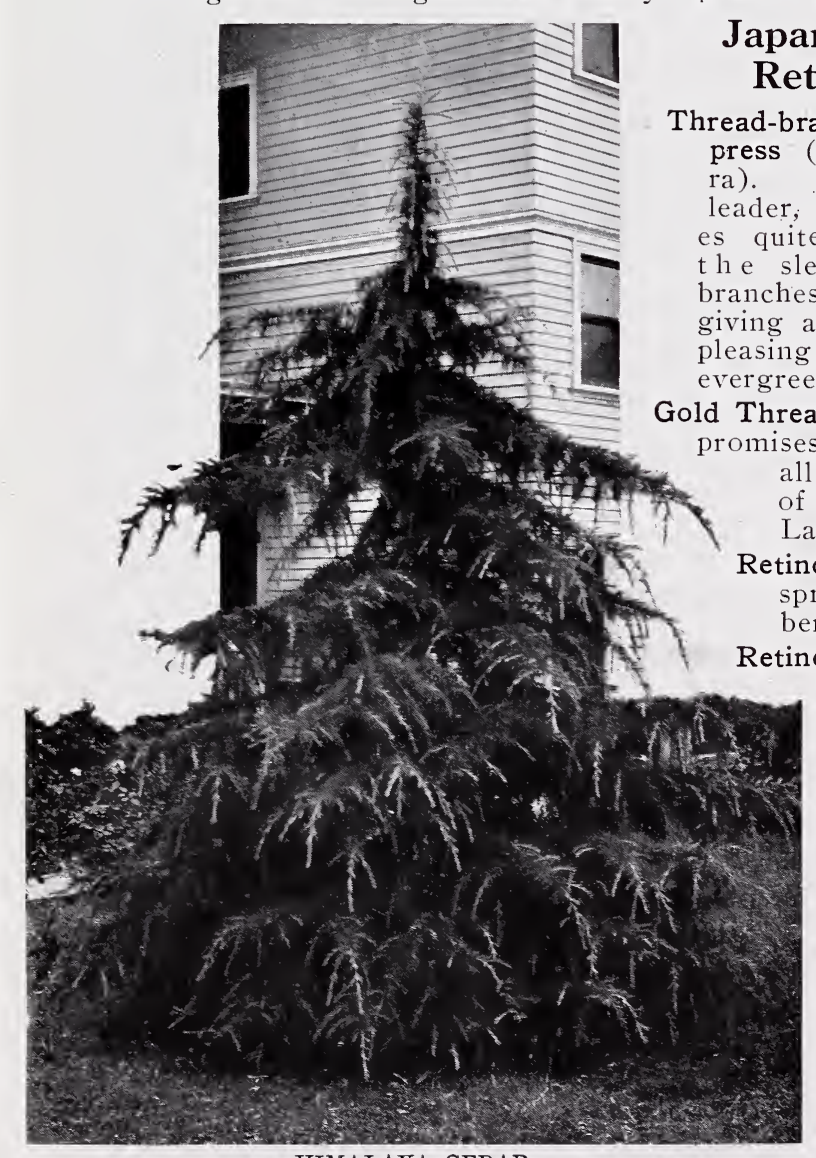

HIMALAYA OEDAR

"Cedrus Deodora" on 23rd street between Everett and Flanders, Portland, Oregon.

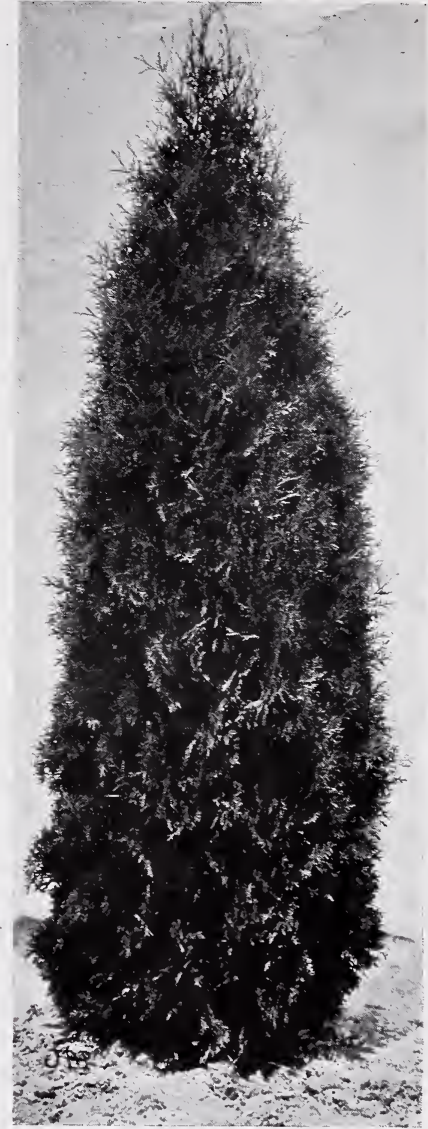

PIRAMIDAL ARBORVITAE (See page 36 ). branches are of a peculiarly graceful and weeping habit, ing a very choice effect to the whole. Foliage of a leasing light green shade. One of the showiest of hardy Large, $\$ 2.00$ to $\$ 3.00$.

Thread-branched Japan Cypress (R. var. aurea). This es to be one of the handsomest of the family, with all the gracefulness of the last, and with branches of a beautiful golden color. A great acquisition. Large, $\$ 2.00$ to $\$ 3.00$.

Retinospora obtusa. A tall-growing variety, with spreading, graceful foliage of bright green, glaucous beneath; valuable. $\$ 1.50$ to $\$ 3.00$.

Retinospora obtusa var. aurea. Of slower growth and foliage; decidedly golden; rare. $\$ 2.00$ to $\$ 3.00$.

Retinospora pisifera. Fine feathery green foliage, Pendulous and good form.

Retinospora pisifera aurea. Fine, feathery, golden foliage, pendulous and good color. $\$ 1.00$ to $\$ 2.00$.

Plumed Retinospora (Retinospora plumosa). One of the best of Japanese introductions being hardy and graceful, with delicate glaucous foliage. 75 cts. to $\$ 2.00$.

Golden Plumed Retinospora (var. aurea). Beautiful and valuable variety. Its shoots are golden tinted through the year, and brighter in the winter. It is unsurpassed for massing. 75 cts. to $\$ 2.50$. 
Japan Retinospora (Retinospora squarrosa Veitchii). A most distinct and valuable sort. Foliage of compact, tufted character; color steel-gray. Grows quite large, but, in common with all Retinosporas, bears shearing in almost any size or form. 75 cts. to $\$ 2.50$.

\section{Cryptomeria}

Cryptomeria ele gans. A beautiful evergreen with delicate green foliage and graceful habit. The color changes to a reddish brown in winter. A very satisfactory evergreen for this latitude. $\$ 1.50$ to $\$ 3.00$.

\section{Fir. Abies}

See also Picea and Spruce.

Colorado Fir (Abies concolor). One of the choicest evergreens, of distinct habit and color, which is a silvery green, and attractive. Rare. $\$ 2.00$ to $\$ 4.00$.

Nordmann's Fir (Abies Nordmanniana). A rare and noble tree, with large leaves of a dark green color main$\mathrm{t}$ a $\mathrm{i} n$ e d through out the year. $\$ 1.50$ to $\$ 3.00$.

Spanish Fir (Abies pinsapo). A mediumsized, tapering tree from the mountains of central and southern Spain. One of the most ornamental of the European Firs. Leaves spreading from all sides of the stiff branches, bright green above, whitened beneath. $\$ 1.00$.

\section{'Hemlock. Tsuga}

Tsuga Sieboldi. A fine, compact, feathery variety from Japan. $\$ 1.50$.

\section{Juniper}

\section{Juniperus}

Juniperus communis. Our common Juniper, light, glaucous foliage. 75 cts.

Irish Juniper (var. Hibernica). Of dense, pillar-like growth. Glaucous green foliage. 75 cts. to $\$ 1.50$.

Golden Japan Juniper (var. a urea). A splendid d warf, golden form. Always bright, and a feature in any planting. Quite distinct and valuable. $\$ 1.50$.

Juniperus Virginiana. Medium growth, tapering form, bright, rich green foliage. Useful for ornmental planting. $75 \mathrm{cts}$. to $\$ 1.50$.

\section{Pine. Pinus}

Austrian Black Pine (Pinus Austriaca Nigra). A remarkably robust, hardy tree; leaves long, stiff and dark green; highly ornamental. Valuable for this country; growth rapid. $\$ 1.00$ to $\$ 2.00$.

White Pine (Pinus Strobus). The most ornamental of all our native Pines. Foliage light, delicate, silvery green. Flourishes in the poorest soils. $\$ 1.00$ to $\$ 2.00$.

\section{Redwood}

\section{Wellingtonia Sequoia}

Big Tree, Mammoth Tree (Wellingtonia gigantea). The largest and oldest of all trees. Native of the Sierra Nevada range of California. Foliage green or bluish-green, complete-
branchlets. This is the and the one most often

\section{Spruce. Picea}

Engelmann's Spruce (Picea Engelmanni). A choice and valuable Rocky Mountain tree, of dense, pvramidal growth. Has the stiff

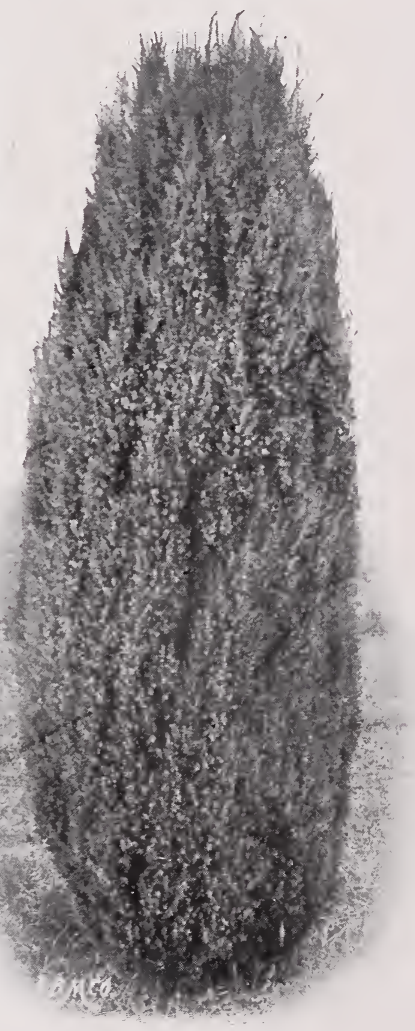

IRISH JUNIPER 
foliage of Pungens, and, in most cases, the fine glaucous color of the latter. An elegant, massive tree. $\$ 1.00$ to $\$ 2.00$; specimens, $\$ 4.00$ to $\$ 5.00$.

Norway Spruce (Picea excelsa). The most generally used of evergreen trees. Useful for screens and windbreaks on account of its rapid growth. It makes a tall tree, and, as an individual tree, with room to develop, is of pyramidal, symmetrical growth, its lower branches sweeping the ground. 50 cts. to $\$ 2.00$. (See, also, Hedge Plants.)

Colorado Blue Spruce (Picea pungens). Few trees are as much sought for as this. Large quantities are sold, but the really silverblue varieties are not plentiful. The tree forms a dense, pyramidal specimen, with stiff, pungent foliage and clusters of cones. Hardy.

The illustration of this magnificent conifer will give a fair impression of the silvery sheen of a really high-colored tree when at

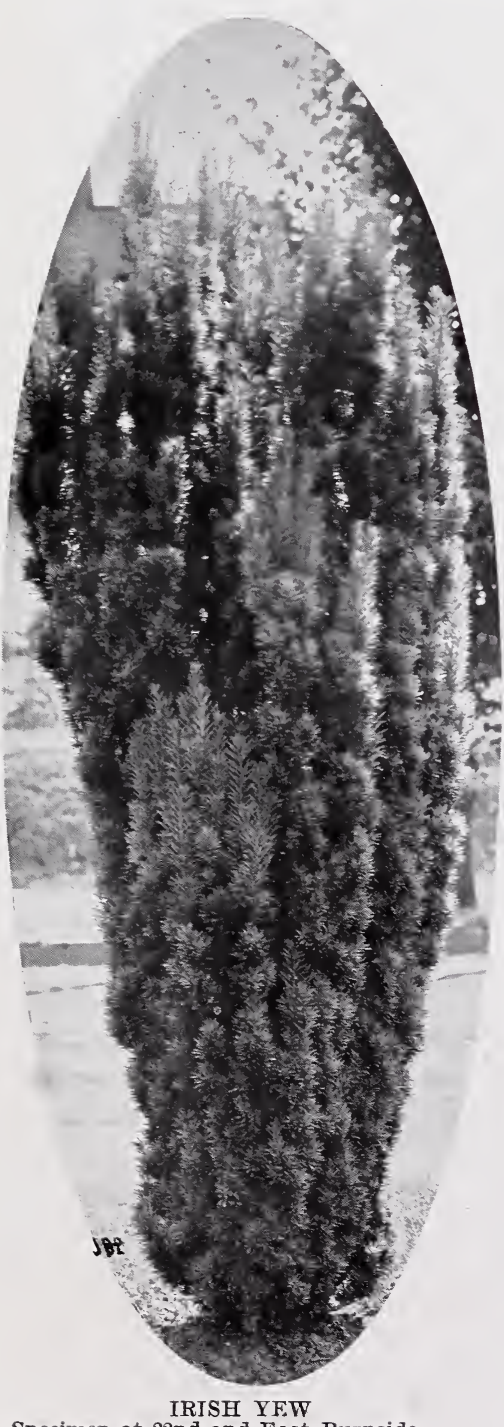

Specimen at 22nd and East Burnside.

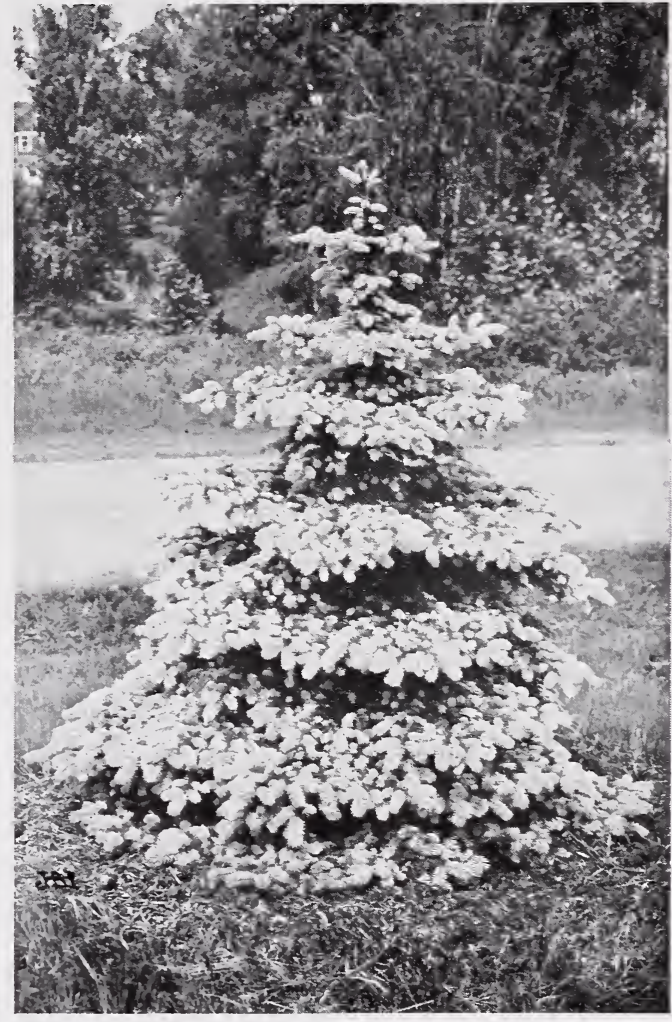

COLORADO BLUE SPRCCE stands $\mathrm{the}$ it e best. green tree c a $n$ exce it, as it has the advant a g e of $\mathrm{grow}$ in $\mathrm{g}$ vigorous ly w $h$ e $r$ e $m$ a $n$ y evergree $\mathrm{n}$ pearance surpasses any of the taller coniferous trees, with the possible exception of Albies concolor. I grow an enormous stock of this Spruce, my trees being grafted from the finest colored specimens in the country, and I can offer it in many sizes from one foot up. Prices of highly colored trees, 12 to 18 inches, $\$ 1.50 ; 18$ to 24 inches, $\$ 2.50$; specimens, $\$ 5.00$ to $\$ 10.00$.

\section{Umbrella Pine. Sciadopitys}

Umbrella Pine (Sciadopitys verticillata). A remarkable and beautiful Japanese tree with compact, ascending branches, forming a narrow, pyramidal head, or, in age, the branches spreading or pendulous. Foliage in whorls of fifteen to thirty stiff, broad needles of a lustrous, deep green color, 3 to 5 inches long. This beautiful tree thrives over a wide range of country, enduring temperatures much below zero. A gem for any garden. $\$ 1.50$ to $\$ 3.00$.

\section{Yew. Taxus}

English Yew (Taxus baccata). Large bush form, having numerous branches, slightly spreading, covered with fine, dark green foliage. Makes a handsome tree for landscape planting, and, owing to the depth of color, is very useful for contrasting with other sorts. 75 cts. to $\$ 2.50$.

Beautiful Variegated Yew (Taxus baccata elegantissima). One of the most valuable golden-leaved evergreens which we have. In June and July the leaves of the new growth are of a bright straw color, rendering the plant highly effective, either by itself, or in connection with other conifers. One of the hardiest of the Yews. $\$ 1.50$ to $\$ 3.00$.

Irish Yew; Fastigiata (Taxus Hibernica). Remarkably upright in form; very distinct; foliage is of the deepest green; very compact habit. $\$ 1.00$ to $\$ 3.00$.

Golden Irish Yew (var. aurea). The leaves are green in the center and margined with yellow. $\$ 1.00$ to $\$ 3.00$. 


\section{Roses}

Years of experience enable me to offer the following desirable varieties. As I grow over two hundred varieties in the nursery, the list enumerated does. not cover all, but many varieties are undergoing trial, while others are in little demand; hence my wish to suppress sale of them and promote the planting of only the best. The Pacific Northwest is noted for its Roses and Portland as the "Rose City." In a section where Roses are so easily grown, the nurseryman is enabled to give splendid values. My plan is to sell strong plants, that produce immediate results, at popular prices. Special prices on orders in 100, 1,000, 5,000 and 10,000 lots.

\section{Hybrid. Perpetuals}

These constitute a very striking and distinct family of Roses, easily distinguished from all others by their luxuriant foliage, prodigious blossoms and vigor of growth. They are perfectly hardy and of very robust habit, thriving with little care or attention. The more vigorous growers require close pruning. Although styled perpetual bloomers, they are not so in reality, blooming only in the spring and fall. As a class, they are deservedly popular, varying in color from snowiest white to the deepest crimson. Two year old plants, 25 cts. each; $\$ 3.00$ per dozen; extra large plants, 35 cts. each; $\$ 4.00$ per dozen. I give 13 plants for a dozen.

Alfred Colomb. Bright cherry-red, to deep crimson.

American Beauty. Rosy crimson.

Anne de Diesbach. Brilliant carmine-rose.

Baron de Bonstettin. Dark crimson, full and fragrant.

Baroness Rotshchild. A beautiful light rose. Immense blooms.

Black Prince. Deep dark crimson, richly shaded.

Captain Christy. Deep flesh-color.

Captain Hayward. Crimson-carmine; large and fragrant.

Countess of Oxford. Carmine-red, free bloomer.

Duke of Edinburgh. Bright carmine; large and fine.

Fisher Holmes. Lively crimson.

General Jacqueminot. Glowing scarlet-crimson. Great favorite.

Gloire de Bourg La Reine. Vivid red; vigorous.

Gloire de Margottin. Red; full, perfect form; bush or pillar Rose.

Jules Margottin. Superb cerise-red.

Frau Karl Druschki. Flowers are very large; beautiful, pure silvery white, with very deep bud. This is the best white Hybrid Perpetual yet introduced and one of the best novelties of recent years. See picture, taken in my nursery. Sold heretofore at 50 cents or more.

Mabel Morrison. Pure white.

Mad. Gabriel Luizet. Pink, or coral-rose. Fine flower.

Magna Charta. Bright pink, suffused with carmine.

Margaret Dickson. Pure white, with pale center.
Marie Baumann. Carmine-red.

Merville de Lyon. Pure white, washed with satiny rose.

Mrs. R. G. Sharman-Crawford. Rosy-pink; fine.

Mrs. John Laing. Soft pink; large, and fine form; free bloomer and fragrant.

Paul Neyron. Deep rose; enormous size; fine grower.

Prince Camille de Rohan. Very dark crimson; fragrant.

Ulrich Brunner. Cherry-red, flamed scarlet; long stems, almost thornless.

Vick's Caprice. Light pink, striped white and carmine.

Xavier Olibs. Dark maroon-red. The blackest Rose known.

\section{Hybrid Teas}

The Roses in this group are much stronger growers than the preceding, and combine free-flowering qualities with the rich coloring of the Hybrid Perpetuals. Two year old plants, 25 cts. each; $\$ 3.00$ per dozen; extra large plants, $35 \mathrm{cts}$. each; $\$ 4.00$ per dozen.

White La France (Augustine Guinoisseau). Color white, slightly tinted with blush.

Belle Siebrecht. Brilliant rich deep pink. A valuable addition.

Bessie Brown. Very large, full flower; color creamy white, very free-flowering and scented, vigorous, one of the best in this class.

Duchess of Albany. Deep, rich pink, darker than the La France, its parent.

Gloire Lyonnaise. Pale lemon-yellow, tinted with pure white.

Gruss an Teplitz. Richest crimson-scarlet; very free-flowering and fine foliage, making it a most valuable Rose for massing and for hedges.

Kaiserin Augusta Victoria. Creamy white; one of the best; free bloomer and good form.

La France. Delicate silvery-rose. The best known and one of the most popular in this class.

Lady Battersea. Deep cherry-crimson, long pointed buds.

Liberty. Rich velvety crimson; free-flowering. Fine buds.

Mad. Abel Chatenay. Bright rosy carminesalmon, shaded vermilion.

Mad. Caroline Testout. Very large, globular flower, color bright satiny rose, darker center, edges of petals bordered with soft car- 


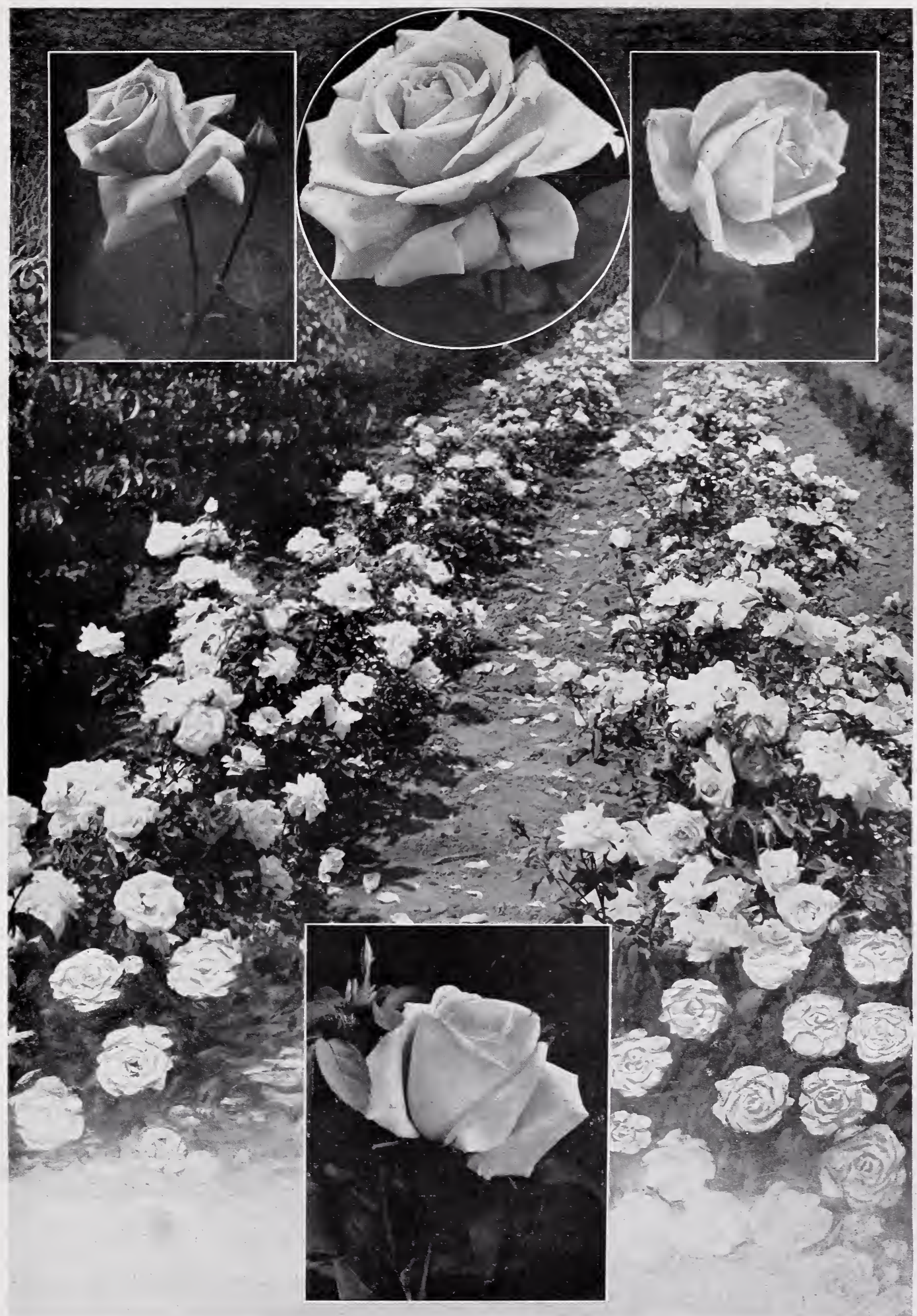

FRAU KARL DRUSCHKI BLOOMING IN NURSERY ROWS 


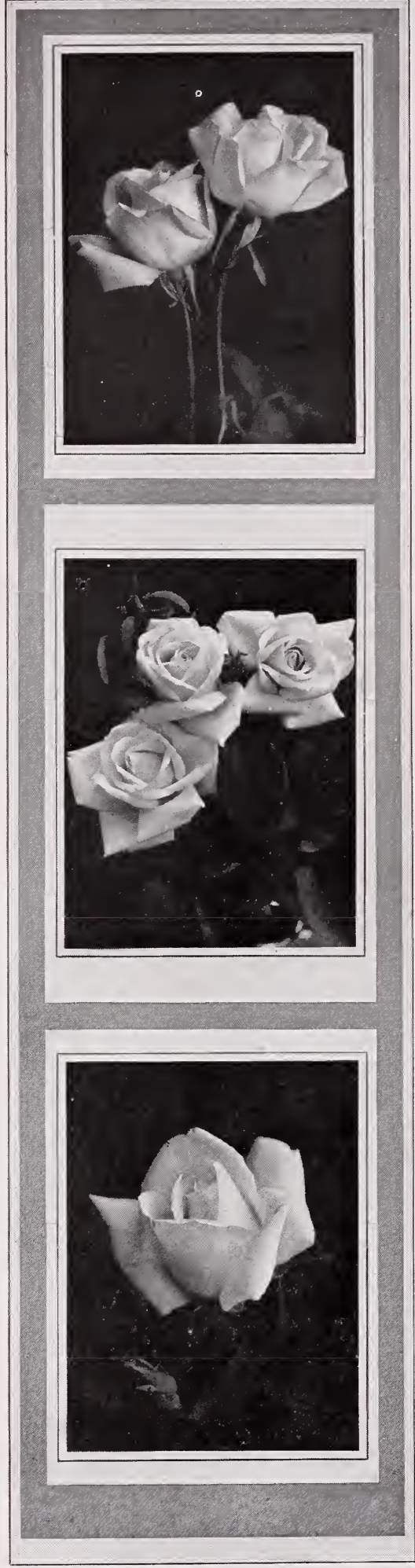

BRIDE AND BRIDESMAID MARIE VAN HOUTTE PAPA GONTIER mine-pink; exceedingly free-flowering and vigorous. A most valuable Rose for all purposes, somewhat resembling the La France, but surpassing that Rose by its deeper and more brilliant coloring, and the better shape and profustion of its flowers. (The Portland, Oregon, Carnival Rose.)

Meteor. Rich, velvety crimson. Flowers large and very double.

Mrs. J. W. Grant. (See Belle Siebrecht.)

Richmond. One of the best red Roses yet produced, and a perfect forcing Rose. It comes to perfection with very little care. It is a constant bloomer, very fragrant, with a color approaching a deep scarlet in tone. It has long, pointed buds, on tall, straight stems, with elegant dark foliage. A superb Rose in every sense of the word.

Souv. du Pres. Carnot. Delicate rosy-flesh, shaded deeper at the center. A fine Rose.

Viscountess Folkstone. Soft rose color, with dark center.

White La France. (See Augustine Guinoisseau.)

\section{Tea $a_{s}^{*}$ or Everblooming Roses}

Considered finest of all for general purposes. Two year old plants, 25 cts. each; $\$ 3.00$ per dozen; extra strong plants, 50 cts. each; $\$ 4.00$ per dozen.

Anna Oliver. Rosy flesh, reverse of petals shaded salmonpink.

Bon Silene. Deep rose.

Bride. Pure white.

Bridesmaid. Clear pink. Very popular.

Catherine Mermet. Pale flesh-color; free-bloomer.

Cornelia Cook. Creamy-white; fine buds.

Countess Riza de Parc. Coppery-rose, purged with crimson.

Dr. Grill. Coppery-yellow, tinted China pink.

Duchess de Brabant. Brilliant rosy-pink.

Etoile de Lyon. Deep yellow, very double, good foliage.

Francesca Kruger. Coppery-yellow, shaded with peach.

Golden Gate. Creamy-white, center soft yellow shaded.

Helen Gould. Rosy-pink.

Homer. Flesh-colored rose, edged with lilac-rose.

Isabella Sprunt. Lustrous lemon-yellow.

Ivory. Pure ivory-white.

Mad. Francesca Kruger. (See Francesca Kruger.)

Mad. Hoste. Long buds; color pale lemon-yellow, with deeper center.

Maman Cochet. Clear pink, changing to silvery-rose. One of the best.

Maman Cochet, Red. Bright cherry-red.

Maman Cochet, White. A creamy-white, tinged with soft blush. A general favorite.

Maman Cochet, Yellow. A beautiful light clear yellow.

Marie Van Houtte. Canary-yellow, tipped with bright rose.

Papa Gontier. Brilliant carmine, changing to rose and lilac.

Perle des Jardins. Golden-yellow: One of the finest.

Queen. Beautiful creamy-white.

Rainbow Improved. Pink, striped with carmine.

Safrano. Apricot-yellow.

Souv. Pierre Notting. Apricot-pink, suffused with orange.

Sunset. Deep apricot-yellow.

\section{Climbing Roses}

Including many new varieties. Two year old plants, 25 cts. each; extra strong, 35 cts. each. 
Aglaia. (See Yellow Rambler.)

Ards Pillar. (See New Roses.)

Beauty of Glazenwood (Noisette; Fortune's Yellow). Orange-yellow, shaded carmine.

Cherokee (Class Cherokee). Single, clear white flowers.

Pink Cherokee. (See New Roses.)

Chromatella, or Cloth of Gold (Noisette). Clear, bright yellow.

Climbing Bridesmaid. 'Tea. Clear pink.

Climbing Devoniensis. Tea. Creamy-white.

Climbing Gloire de Dijon. Tea. Creamy-white, with blush tint.

Climbing Kaiserin Augusta Victoria. Hybrid Tea. Creamy-white.

Climbing Mad. Caroline Testout. Hybrid Tea. Bright satiny rose.

Climbing Papa Gontier. Tea. Large flowers, very full, fine, long, pointed buds; color very bright rose, deeper on the outer petals; vigorous and free-flowering.

Climbing Meteor. Hybrid Tea. Deep, rich red.

Climbing Perle des Jardins. Tea. Golden-yellow.

Climbing Safrano. (See Reve d'Or.)

Crimson Rambler (Polyanthus). Free-growing, producing masses of crimson flowers.

Dorothy Perkins (Wichuriana). Soft shell-pink. (See illustration.)

Lamarque (Noisette). White, shaded lemon.

Mad. Alfred Carriere. Hybrid Noisette. White flesh, shaded with salmon.

Marechal Niel. Tea. Rich golden-yellow.

Philadelphia Rambler (Polyantha). Bright crimson.

Reve d'Or (Noisette). Deep yellow, sometimes coppery.

William Allen Richardson (Noisette). Coppery-yellow, flushed with carmine.

White Rambler (Polyantha). Pure white.

Yellow Rambler (Polyantha). Yellow.

\section{Miscellaneous Roses}

Two year old plants, 25 cts. each; $\$ 3.00$ per dozen.

Bardou Job. "Bourbon." Semi-climbing. Single flowers of richest velvety crimson; very fine.

Crested Moss. Moss. Pale rosy-pink, beautifully crested.

Crimson Moss. Moss. Dark carmine-red Moss Rose.

White Moss. Moss. White flowers in clusters.

Baby Rambler (Mme. Norbert Levavasseur). Poly. A cross between Crimson Rambler and one of the Polyantha sorts, but instead of climbing it forms a dark, compact bush, not over 18 inches high, loaded down with heavy clusters of bright crimson flowers similar to Crimson Rambler. It blooms from early spring until late in the fall, and is destined to become one of the most popular varieties for bedding. No admirer of Roses should be without it.

Persian Yellow. Austrian. Fine, deep golden-yellow.

Rugosa rubra. Single, deep rosy-carmine. Vigorous grower, fine for massing and hedges. (See Hedge Plants.)

Rugosa alba. Same, with white flowers.

Wichuriana type. Single white, small, almost evergreen foliage, very handsome. Japanese origin.
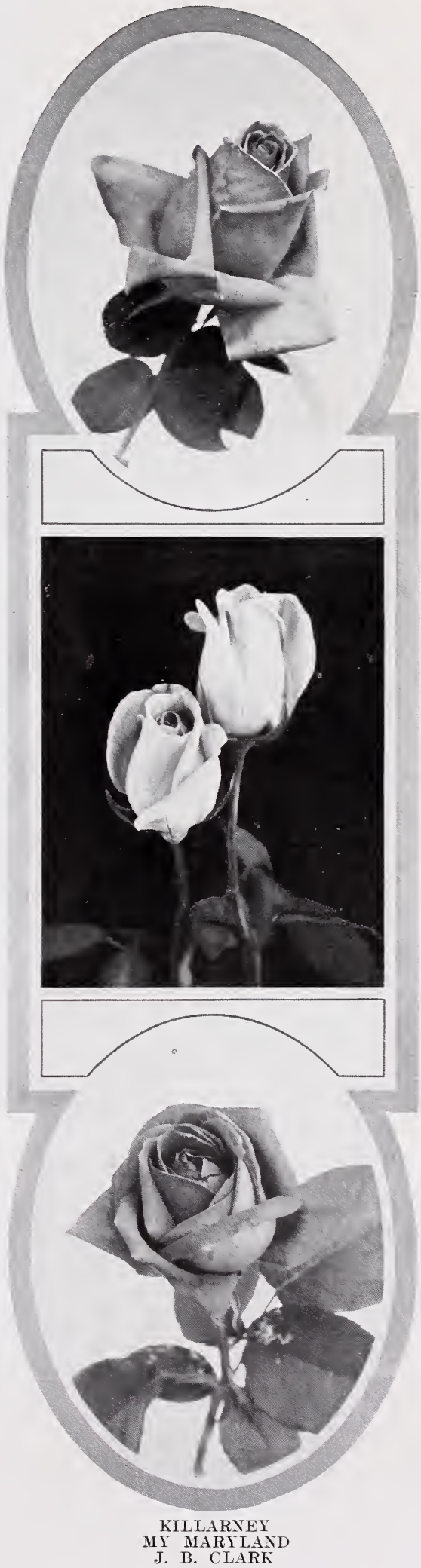


\section{New and Higher Priced Roses}

Ard's Pillar. Climbing H. T. Rich, velvety crimson, full flower. 75 cts.

Betty. H. T. Large coppery Rose with golden-yellow. $50 \mathrm{cts}$.

Chas. J. Grahame. H. T. Fine orange-crimson, fragrant, free. $50 \mathrm{cts}$.

Dean Hole. H. T. Gold medal. Silvery carmine, shaded salmon. $50 \mathrm{cts}$.

Dorothy Page Roberts. H. T. Gold medal. Large, massive petals of great substance, lovely shade of coppery-pink, suffused with apricot-yellow. $\$ 1.00$.

Elizabeth Barnes. H. T. Yellowish-pink, fawn center, free bloomer. $\$ 1.00$.

Etoile de France. H. 'T. A Rose of marvelous beauty and perhaps the most valuable addition made to its class during the past decade. Very vigorous in growth and of robust constitution, forming large, upright bushes with but few thorns. Foliage bronze-green, fine long bud, coming singly and carried on stiff, erect stems. The blooms are very large, petals of good substance a n d c u p ped form ; very full and opening freely. Superb color velvety crimson, center vivid cerise, very fragrant. Flowers 1 as t a long time. 50 cts.

Florence Pemberton. $\mathrm{H}$ : T. Gold medal Rose of the English N: R. S. Took second prize $\mathrm{bes} t$ individual specimen Rose at Portland Rose Exhibit, June, 1910. Large full flowers, perfectly formed. creamy-white with suffused pink. $50 \mathrm{cts}$.

Franz Deegan. H. T. This Rose will certainly prove worthy of extensive cultivation and will win its way in to favor wherever planted. In color it resembles the popular Perle des Jardins, the inner petals approaching more of an orange shade. It throws up very strong canes and the flowers stand up erect on the stems and are of superb form. $50 \mathrm{cts}$.

General McArthur. H. T. Large, full flower, well formed; color dark velvety crimson; vigorous, American origin; largely advertised as a most reliable Rose. 50 cts.

Grace Darling. H. T. Large, full flower, well formed; color creamy-white, tinted and shaded with peach, free-blooming and vigorous; a most valuable Rose. 50 cts.

Harry Kirk. T. Gold medal. Deep sulphuryellow; full, fine buds. $\$ 1.00$.

Hon. Ina Bingham. H. T. A fine Rose, even superior to Killarney. Purest pink, deeply veinated, flowers semi-double, enormous petals. Distinct new color. 50 cts.

Hugh Dickson. H. P. Large flowers, very full and well formed, opening well in all weathers; color brilliant crimson, shaded scarlet; very free-flowering and vigorous. A Rose of great beauty on account of its superb dark coloring and exquisitely forméd flowers: awarded gold medal N. R. S. 50 cts.

J. B. Clark. H. T. Very 1 a rge flower, finely formed; full, w it h h igh pointed center; color intense deep scarlet, heavily shaded with blackish crimson; vigorous, a magnificent R o s e, awarded gold medal N. R. S., and a 1 so, first premium best individual $\mathrm{R}$ o s e, June, 1910, Portland Rose Exhibit. 50 cts.

Killarney. H. T. The great Irish Rose. A charming Rose of robust growth ; color bright carmine, - pinkmarbled in c r e a $\mathrm{m} \mathrm{y}$ white; petals extremely large and of a texture that makes it one of the most lasting of Roses. Has an extremely long bud, produced on a long, stiff stem. A favorite Rose for florists for planting in the open. 50 cts.

Lady Ashtown. H. T. Fine, long pointed buds, very large flowe r; full, carried on erect, stiff stems; large petals; color pale rose, shaded with yellow, reflexed silvery; vigorous; most valuable for massing and cutting. 75 cts.

Lyon Rose. R. P. A ing habit of growth, with straight and unequal thorns; the foliage is ample and consists of fine to seven leaflets of a deep reddish green color. The flowers are generally produced singly, though two or three occasionally come on the same shoot; the buds are of large size and long, round shape, coral-red in color, strongly tinted with middle chrome-yellow at the 


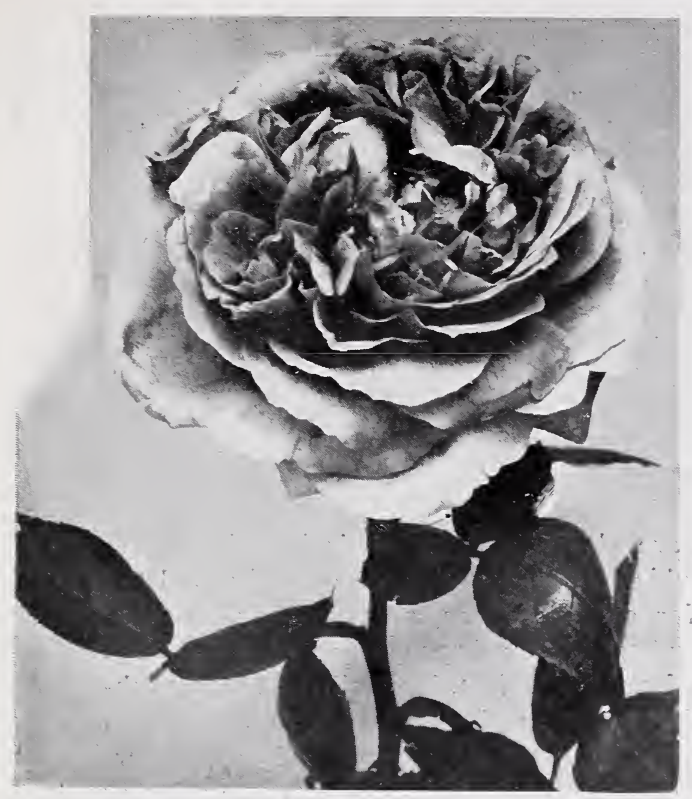

PAUL NEYRON.

base. The blooms are very large, with broad petals, full and globular in form; superb coloring, shrimp-pink at the ends of the petals, center coral-red or salmon-pink, shaded with chrome-yellow, making thus a most happy and charming contrast of colors; very fragrant. Fine, strong bushes, $\$ 1.50$ each

Mildred Grant. H. P. Ivory-white, with a faint flush of pale rose; highly pointed center, with large petals, opening to perfectly formed flowers of enormous size and substance; vigorous. A splendid exhibition Rose: awarded gold medal, N. R. S. 50 cts.

Mrs. Edw. Mawley. T. Gold medal. Pink-carmine, shaded salmon. 50 cts.

Mrs. Stewart Clarke. H. T. Gold medal. Cherry-pink, white base. Large, full. \$1.00.

My Maryland. H. T. Intense glowing pink. One of the freest bloomers and growers known. See illustration. 75 cts.

Pink Cherokee. Climber, single flowers, like the old White Cherokee, but beautiful pink color. $50 \mathrm{cts}$.

Souv. de Catherine Guillot. T. Coppery-red on orange-yellow. Fine, free. 50 cts.

Soleil d'Or. R. P. A hybrid of Persian-yellow. Flowers large, globular, varying in color from gold to reddish-gold, shaded with nasturtium red. A striking novelty. $50 \mathrm{cts}$.

W. E. Lippiat. H. T. Dark velvety crimson; distinct, free. $\$ 1.50$.

William Shean. H. T. Gold medal. Pink with ochre veins. Novelty. Fine. \$1.00.

\section{Additional New Roses}

In addition to the varieties of new Roses just described, I offer for late fall and early spring planting, the latest productions of the famous rose growers of Great Britain, France, Germany, Holland and Belgium. The recent rize winners at European Rose shows will be in stock as soon as importations arrive. Rosarians are requested to send list of their wants, on which I will gladly quote special prices. issued during October; copy will be mailed on request.

\section{Standard or Tree Roses} all varieties are successful, but I offer the ollowing, which have given good results. Many ther varieties can be supplied.

1.00 each; $\$ 10.00$ per dozen.

Baby Rambler. Bright crimson.

Baroness Rothschild. Deep flesh color.

Captain Hayward. Crimson-carmine.

imson Rambler. Crimson.

au Karl Druschki. Pure silvery-white.

eneral Jacqueminot. Glowing scarlet-crimson.

d'Dijon. Creamy-white and blush.

Teplitz. Rich crimson-scarlet.

France. Delicate silvery-pink.

Mad. Abel Chatenay. Bright rosy carminesalmon.

Mad. Caroline Testout. Bright satiny-rose.

Magna Charta. Bright pink, suffused carmine.

Marechal Neil. Rich golden-yellow.

Mrs. John Laing. Soft pink.

Prince Camille de Rohan. Very dark crimson.

Ulrich Brunner. Cherry-red, flamed with scarlet.

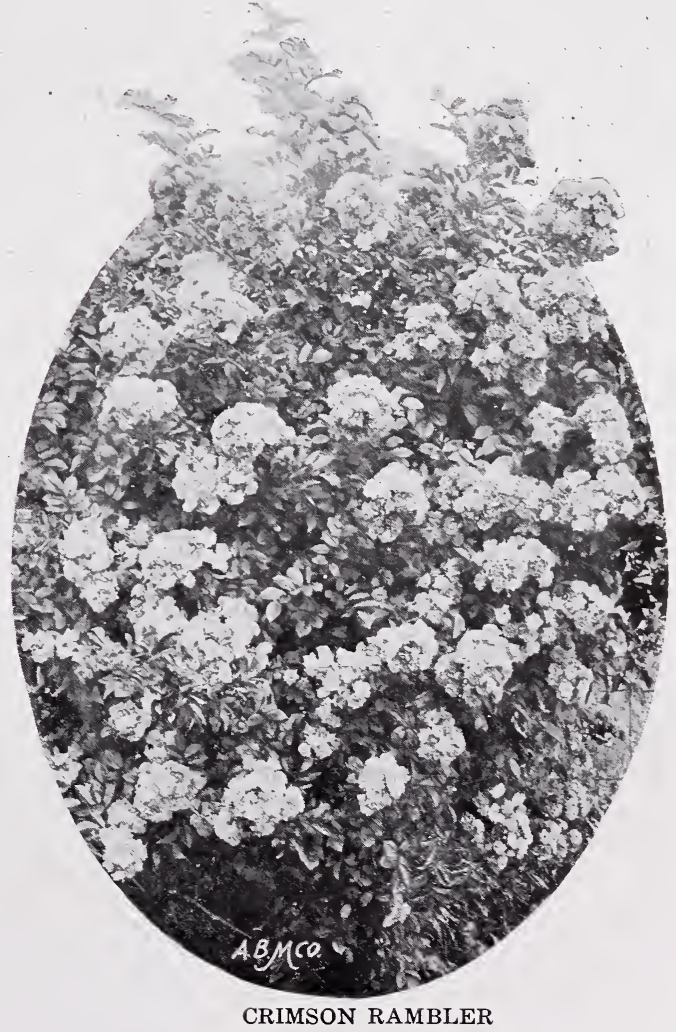



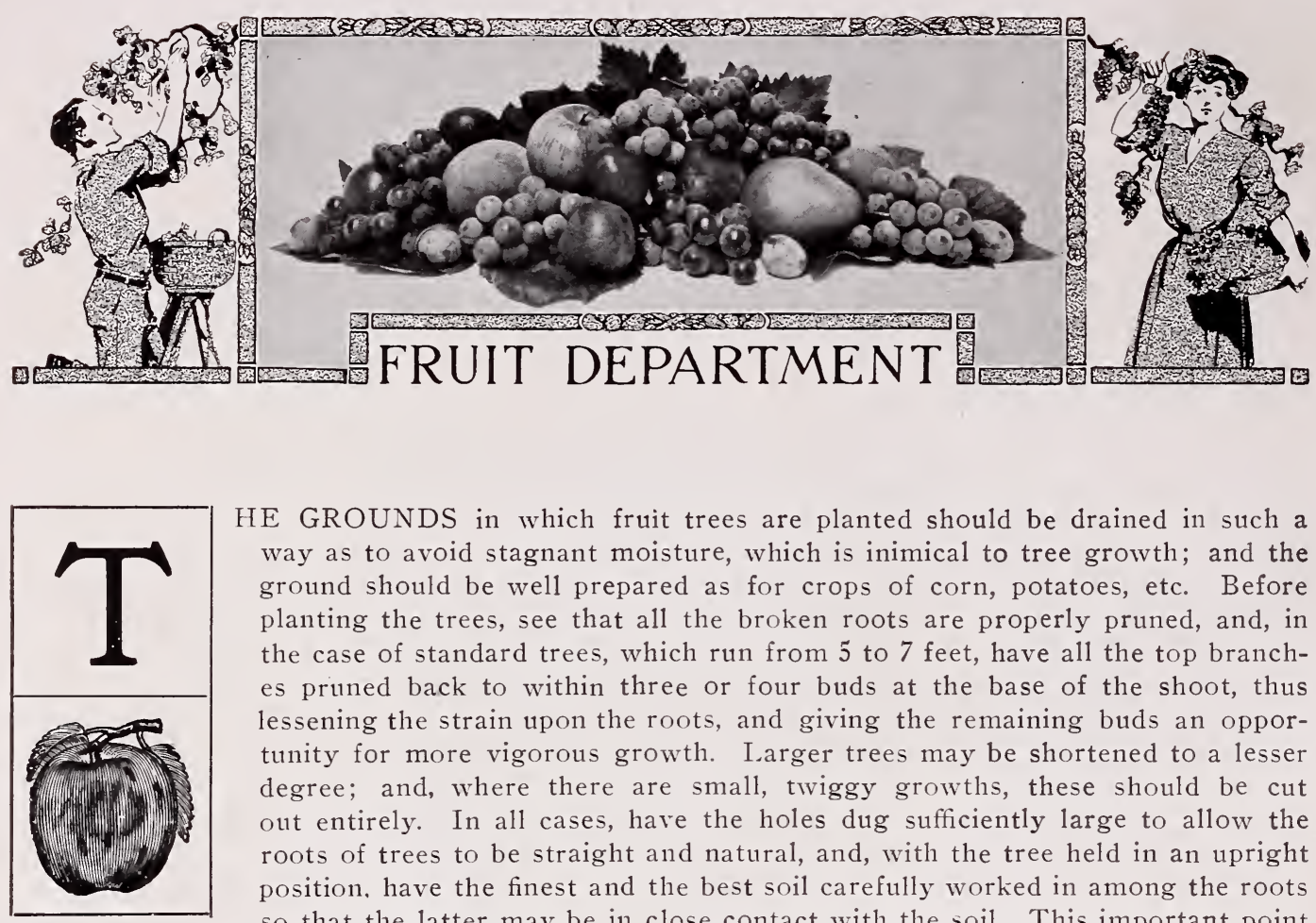

HE GROUNDS in which fruit trees are planted should be drained in such a way as to avoid stagnant moisture, which is inimical to tree growth; and the ground should be well prepared as for crops of corn, potatoes, etc. Before planting the trees, see that all the broken roots are properly pruned, and, in the case of standard trees, which run from 5 to 7 feet, have all the top branches pruned back to within three or four buds at the base of the shoot, thus lessening the strain upon the roots, and giving the remaining buds an opportunity for more vigorous growth. Larger trees may be shortened to a lesser degree; and, where there are small, twiggy growths, these should be cut out entirely. In all cases, have the holes dug sufficiently large to allow the roots of trees to be straight and natural, and, with the tree held in an upright position, have the finest and the best soil carefully worked in among the roots so that the latter may be in close contact with the soil. This important point will save the loss of many trees. Trees which are tall enough to be shaken by the wind should be carefully staked, with a piece of cloth tied about the tree to prevent rubbing of the bark by either the stake or tying material. After planting, have the grounds, as far as the roots extend, well mulched, several inches deep, with manure. This protection, in dry ground especially, is beneficial as it prevents the cracking or drying out of the ground and provides a very even moisture about the roots. Keep the ground about young fruit trees cultivated and open, not allowing the grass to grow about them.

The number of plants required for an acre, at any given distance apart, may be ascertained by dividing the number of square feet in an acre $(43,560)$ by the number of square feet given to each plant, which is obtained by multiplying the distance between rows by the distance between the plants. Thus, Strawberries, planted $3 \times 1$ foot, gives each plant 3 square feet, 14,520 plants to the acre.

Planters who intend setting out commercial orchards, no matter what size, are requested to send lists of their wants in the way of fruit trees, berry bushes and vines. Prices are low in quantities. The prices herein quoted are for first-class selected stock of the sizes specified. Experienced horticulturists and orchardists universally prefer the one year, 4 to 6 foot tree for extensive planting. Two year old or larger trees for quick results are desired for city planting or where only a few trees are desired and uniformity in the orchard is of no importance. Home grown Dwarf Apples and Pear trees can now be supplied. See page 58.

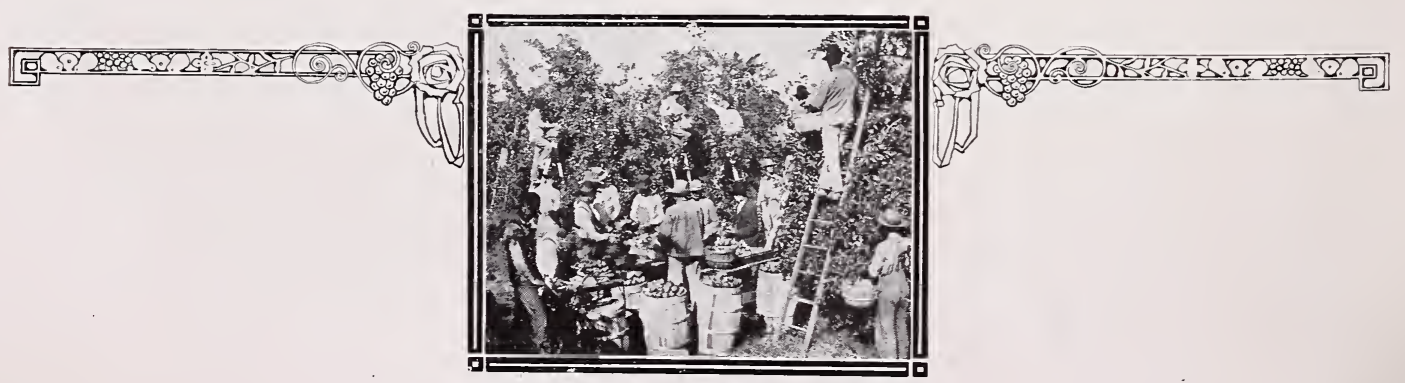




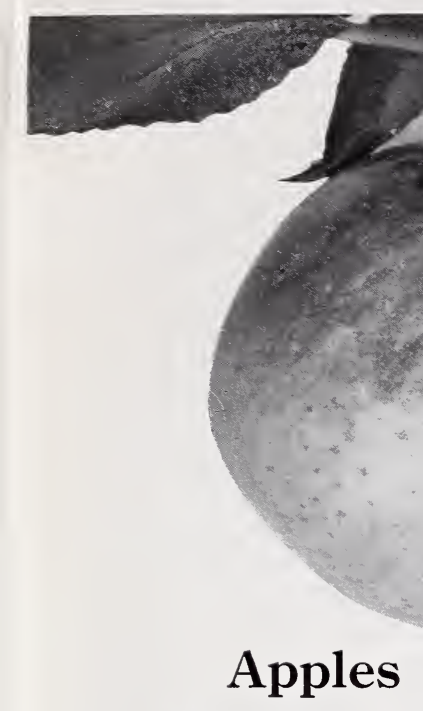

The following list of Apples e mbraces varieties which have been tested, a n d c a n be recommended as the very best for general cultivation. A few others are grown in limited quantity. Inquire for anything not listed here. All Apples are furnished in standard sizes. Dwarf trees are listed elsewhere.

One year, 4 to 6 feet, $20 \mathrm{cts}$ each; $\$ 15.00$ per 100.

Two year, 5 to 7 feet, branched trees, 35 cts. each.

Extra large selected trees, $50 \mathrm{cts}$ each.

\section{Summer Apples}

Red Astrachan. Free growth; large, roundish; deep crimson; juicy, rather acid; good; very hirdy; highly esteemed on account of its fine appearance, earliness and hardiness. Ripening August.

Yellow Transparent. Free growth; medium; roundish, oblate, slightly conical; pale yellow; tender, juicy, sprightly, subacid; good. Ripening late July.

\section{Autumn Apples}

Gravenstein. Vigorous growth; very large; striped; juicy, tender, crisp, rich, subacid. Ripening September. Very best.

King of Tompkins County. Vigorous growth; large, red-striped; tender, juicy, vinous: very good. Ripening September to October.

\section{Winter Apples}

Arkansas Black. Medium, round: yellow where not covered with a beautiful dark maroon, approaching black; flesh firm, fine-grained, juicy. Valuable for market and a long keeper.

ular winter Apples.

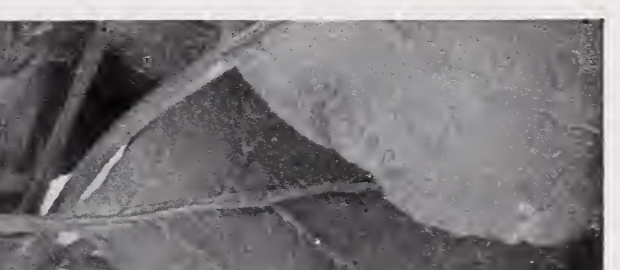

1

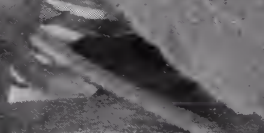

$\int$ RED ASTRACHAN

Baldwin. Large, rounded; deep, bright red; very productive; one of the best and most pop-

Delicious. Still comparatively scarce, is becoming well known as a market variety. Brilliant dark red, with gold near blossom end, large size, fine quality. Tree very hardy and good grower. Price, $\$ 25.00$ per 100. See illusthation page 48.

Grimes' Golden. Transparent, golden-yellow, Medium to large, cylindrical in shape. Tree hardy, vigorous and good, constant bearer. A favorite market apple.

Johnathan. Medium growth; red and yellow; tender, juicy and rich. Very productive. One of the best for table or market.

Newton Pippin. Moderate growth; large; green; juicy, crisp, aromatic; best. Ripening November to June.

Northern Spy. Vigorous growth; large; striped red; tender, juicy, mild, subacid; very good; a fine dessert fruit. Ripening October to December.

Ortley. Excellent quality apple, pale yellow, of the Bellflower type, medium large, regular bearer and good keeper.

Rome Beauty. Large, dark red striped apple, excellent quality, bringing good prices. Tree hardy, regular bearer, late bloomer.

Spitzenberg (Esopus). Large, round, brilliant red, with gray dots: firm, rich, crisp, juicy, spicy and delicious. Tree rather a slow 


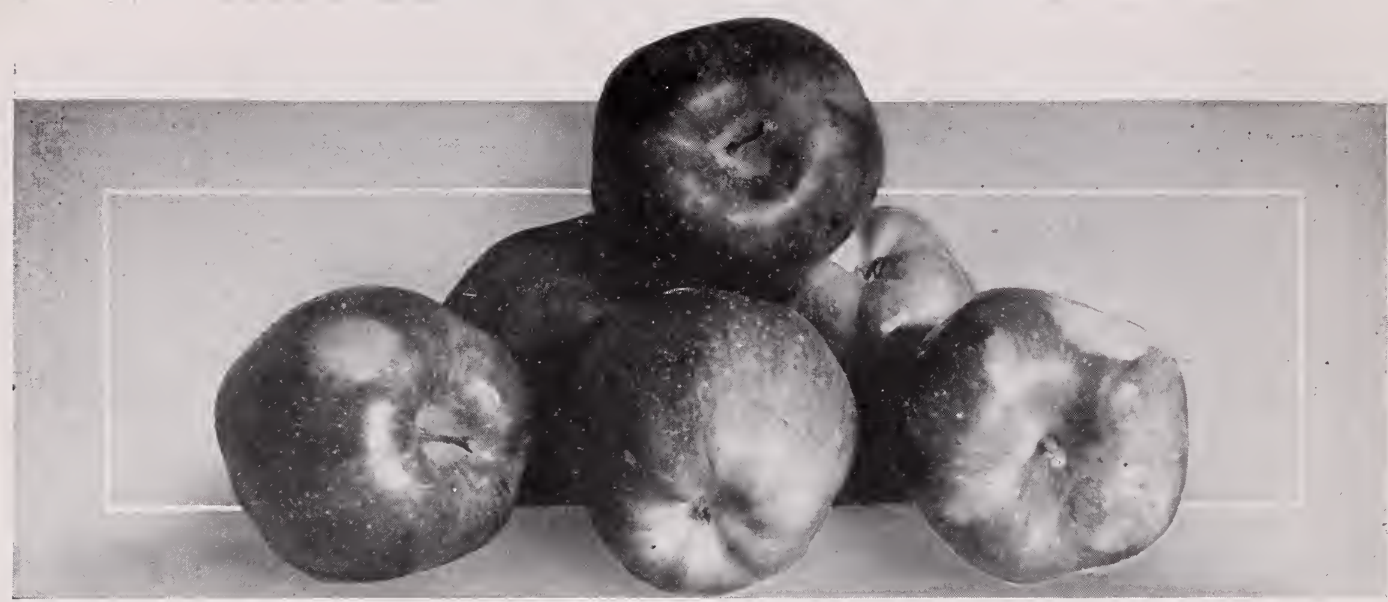

DELICIOUS (See page 47)

grower, but, with high culture, forms a large tree; a good bearer and a popular fruit. Ripening November to January.

Wagener. Brilliant red and light yellow, good quality, especially adapted to high elevations and dry climates.

Winter Banana. Winter; yellow blush cheek; subacid; medium size. Has pronounced banana flavor.

Yellow Bellflower. Free growth; large; yellow; crisp, juicy, acid to subacid; very good. Ripening November to February.

\section{Crab Apples}

Hyslop. Large size; dark crimson, with bloom; very showy and most beautiful of all the class.

Red Siberian. Small; bright red, covered with a light transparent bloom; excellent for preserving. Early September.

Transcendent. Of the largest size of this class of Apples; striped red, showy, excellent and very handsome.

\section{Apricots}

One year, 4 to 6 feet, 25 cts. each; $\$ 20.00$ per 100 .

Large selected trees, 35 cts. each.

Moorpark. Very large; orange, with a reddish cheek; flesh orange, sweet, juicy, with a fine flavor; very valuable. Beginning of August.

Royal. Large; flesh saffron-yellow; juicy, rich and good flavor. August.

Tilton. Large; flesh firm; yellow and decidedly freestone. Regular and heavy bearer.

\section{Cherries}

One year, 4 to 6 feet, $30 \mathrm{cts}$. each; $\$ 25.00$ per 100 . Strong two year old trees, $50 \mathrm{cts}$. each.

Extra large, selected trees, 75 cts. to $\$ 1.00$ each.

Bing. Originated near Portland, Oregon. Fruit immense; black; firm, and very fine. Ripening just before the Royal Ann. Fine for shipping.
Black Tartarian. Very large, black, half tender; sweet, rather rich, fine flavor: deserves general cultivation; tree a strong, upright, beautiful grower and good bearer. Last of June.

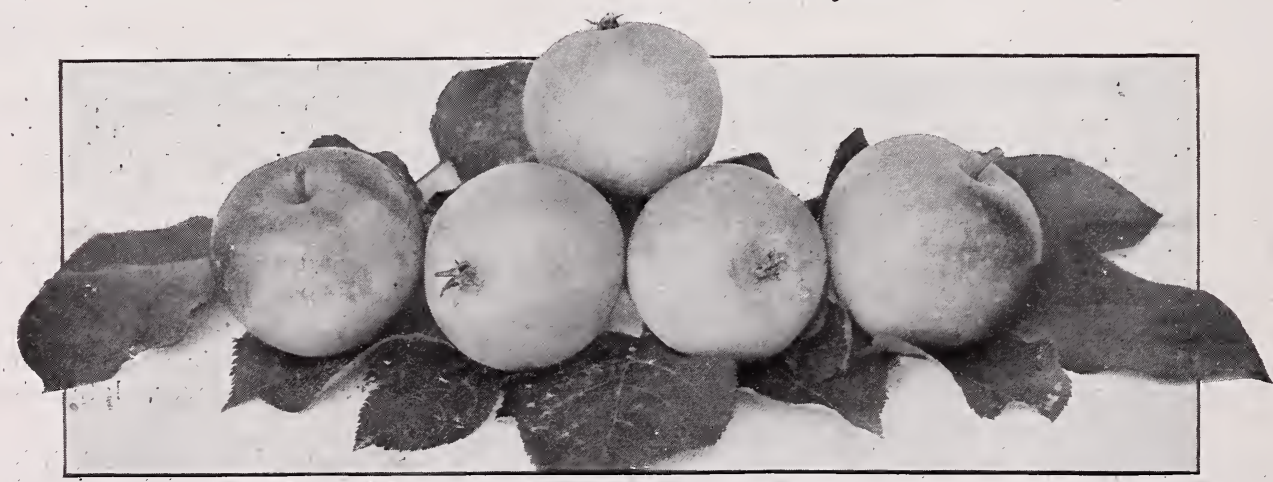

TRANSCENDENT CRAB APPLES. 
Black Republican. One of Seth Luelling's origins. Medium size, very fine, black Cherry. Late.

Kentish (Early Richmond). Medium size; dark red; melting, juicy, sprightly, rich acid flavor; very productive, reliable and hardy. Valuable. June.

Lambert. Large size and good quality; deep rich red, almost black; flesh firm, and flavor unsurpassed. Best shipping variety; regular and heavy bearer. Ripens two weeks later than Royal Ann.

Late Duke. Best late Cherry; large, red and subacid.

May Duke. Large, dark red; juicy and rich; an old, excellent variety; vigorous and productive. Middle of June.

Royal Ann (Napoleon Bigarreau). The best-known Pacific Coast Cherry. Very large; firm; good for canning and shipping, and the best of all red Cherries.

\section{Figs}

Strong rooted trees, $50 \mathrm{cts}$.

Black Ischia. Medium; blue-black; good. Bears abundant crops, and is hardy.

Celestial. Small; pale violet, with bloom; very sweet; prolific and hardy.

\section{Peaches}

One - ear, 4 to 6 feet, 20 to 25 cts. each; $\$ 15.00$ per 100.

Large selected trees, 35 cts. each.

Alexander. Above medium; flesh greenish-white, very juicy, vinous and of good quality; adheres to the stone. Trees are remarkably prolific and bear very young.

Crawford's Early. A magnificent, large, yellow Peach of good quality. Its size, beauty and productiveness make it one of the most popular varieties.

Crawford's Late. Fruit very large, roundish; skin yellow, with dark red cheeks, flesh deep yellow, juicy and melting, with a very rich and excellent vinous flavor.

Elberta. Large; yellow, with red cheek; juicy, and of good flavor; flesh yellow. An excellent shipping variety. No other Peach has made such a name for shipping, and none is cultivated more extensively.

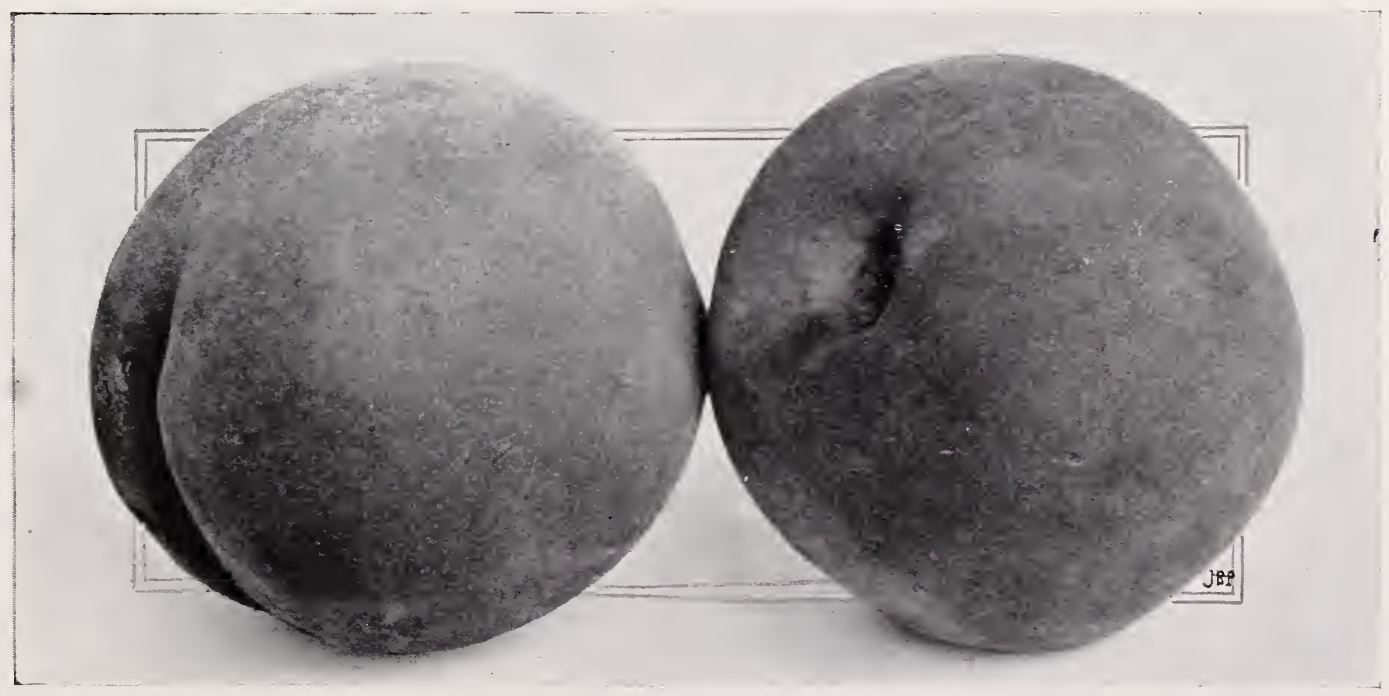




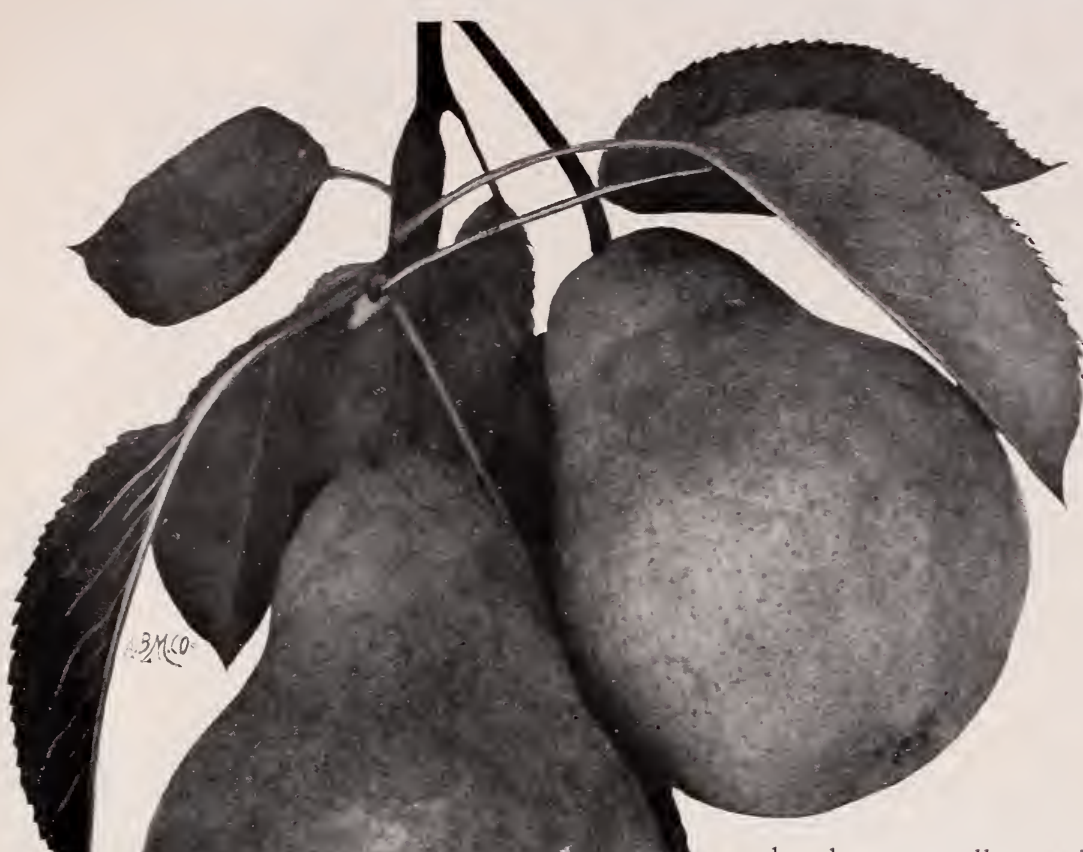

Clapp's Favorite. L a rg e ; resembles Bartlett; ripens a few days earlier; productive. August and September.

Comice. Yellow, faintly b lus he d crimson; fine quality and good keeper. A famous Medford variety.

Bosc. Handsome deep yellow, slightly russet, very highest quality, tender and aromatic.

Anjou. Large; yellowish, somewhat russeted, red cheek; fine grained, buttery, melting and excellent. October to December.

Seckel. Small; dull yellow, with russet and colored cheek; very juicy, buttery and rich; very high flavored and productive; a slow grower. September and October.

P ound. Enormous; very handsome; yellow, with red cheek; much esteemed for cooking. Tree vigorous and productive. Among the latest to ripen.

Winter Nelis. Medium size; dull russet; melting, juicy, buttery and of the highest flavor. Does not bear regularly in some sections. December and January.

\section{Persimmons}

American. Small fruits, orange-yellow with whitish bloom, very astringent until fully ripe or after early frosts. Tree is very hand some, dense dark green foliage, fine for lawns. $50 \mathrm{cts}$.

PEACHES. (Continued)

Foster. Very large; yellow; resembles Early Crawford, but it is a few days earlier and of better quality. Fruit very uniform in size.

Muir. An excellent bearer, and does not curl; fruit large to very large; a fine shipper, and one of the best canning Peaches in the United States; as a drying Peach it excels all others ever introduced.

Salway. Large; yellow, with crimson cheek; flesh deep yellow; very juicy, melting and rich; the most valuable late variety.

\section{Pears}

The soil best adapted for Pear culture should be of rich and heavy quality. The fruit of summer and autumn varieties should be picked as soon as it has attained full size, when, if ripened in dark, dry closets, it is not subject to rotting at the core, and develops its best flavor. Pick winter sorts as soon as the weather indicates the liability of hard frost. Thinning increases size and quality of the remaining crop.

One year old, 4 to 6 feet, 30 cts. each; $\$ 25.00$ per 100 .

Two year old, 5 to 7 feet, 35 to $50 \mathrm{cts}$. each.

Bartlett. Large; clear yellow skin; buttery, very juicy and high-flavored: early and a great bearer. September.

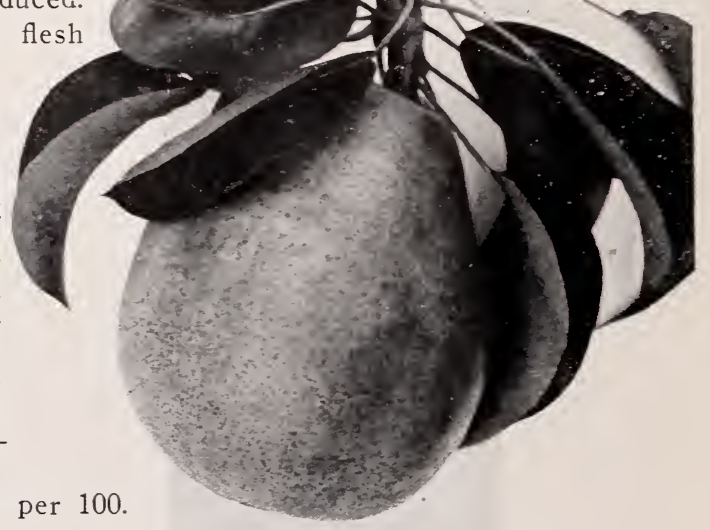


Japanese. Fruit larger and better than American, not so astringent, but tree is not so ornamental. $50 \mathrm{cts}$.

\section{Plums}

One vear old, strong, 4 to 6 feet, 25 cts. each; $\$ 20$ per 100.

Heary selected trees, 35 cts. each.

Bradshaw. Very large, oval; bark violet-red; juicy, sweet and good; a valuable market variety.

Columbia. Very large; round; dark red; rich, vinous flavor; hangs on the tree a long time. Oct.-Nor.

Damson. Small, roundish oval; dark purple: used for preserves. Sept.
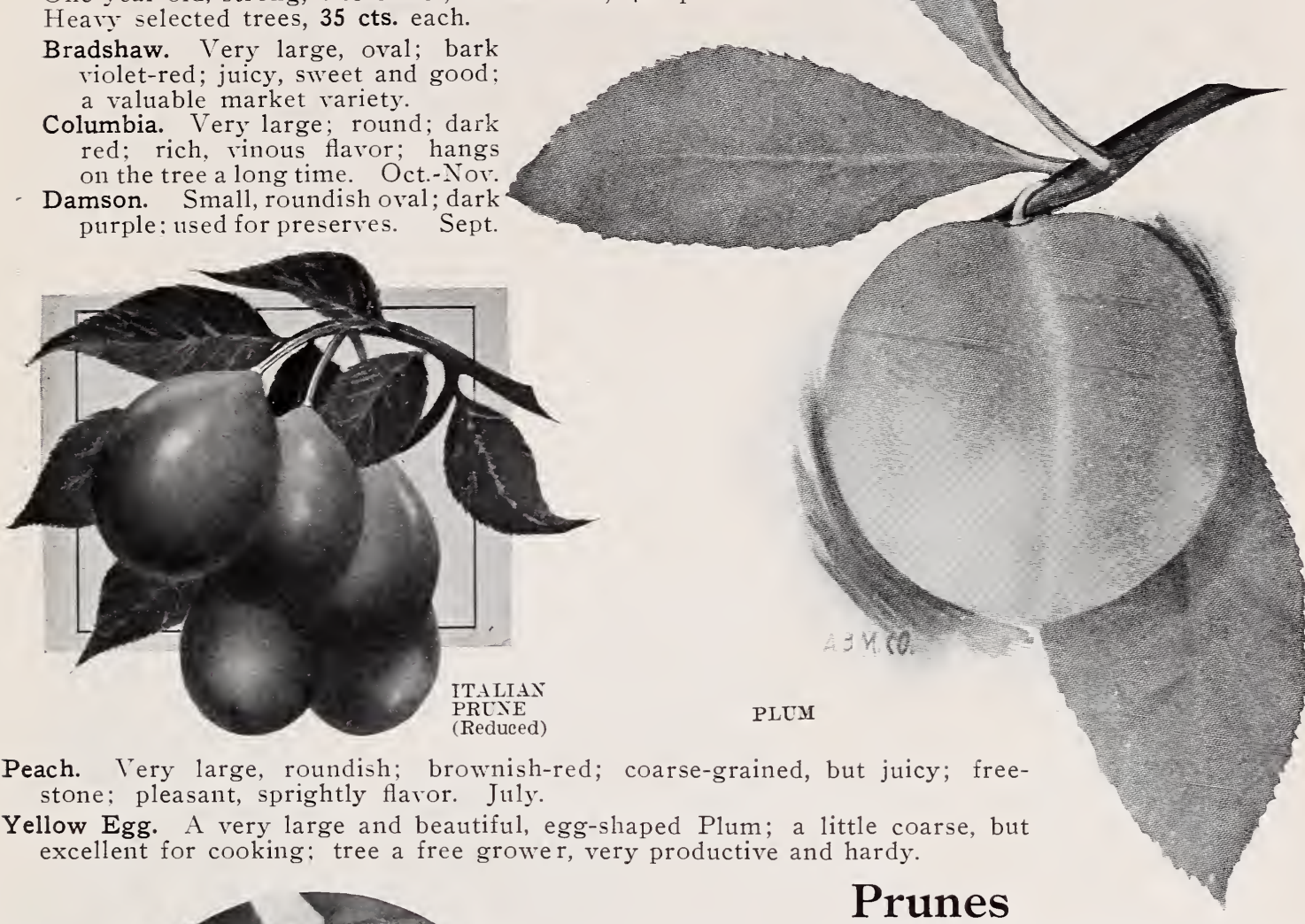

Peach. Very large, roundish; brownish-red; coarse-grained, but juicy; freestone; pleasant, sprightly flavor. July.

Yellow Egg. A very large and beautiful, egg-shaped Plum; a little coarse, but excellent for cooking: tree a free grower, very productive and hardy.

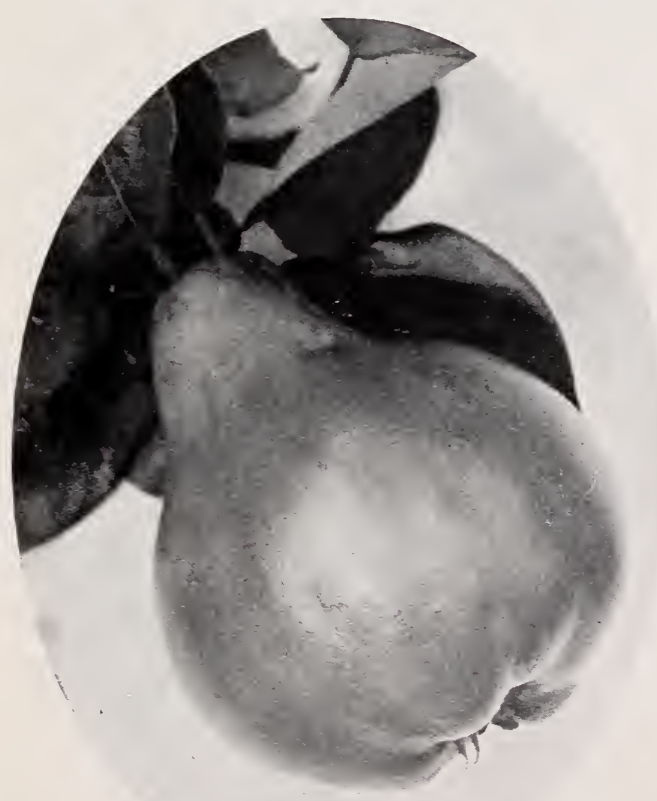

One year old, strong, 4 to 6 feet, 20 cts. each; $\$ 15.00$ per 100 .

Heavy selected trees, 25 to $35 \mathrm{cts}$. each.

French, or Petite. The well-known variety so extensively planted for drying; medium size, egg-shaped; violet-purple; juicy, very sweet, rich and sugary; very prolific.

Hungarian (Grosse Prune, Pond's Seedling). Very large, dark red, juicy and sweet. Its large size, bright color, productiveness, and shipping qualities render it a profitable variety for home or distant market.

Italian. The famous Oregon Prune of commerce. A fine late oval variety. Large, dark purple, the flesh is juicy and delicious. Best for drying. Tree very nroductive. I make a specialty of these and have supplied the trees for many of the best Willamette Valley Prune orchards.

Silver. A seedling of Coe's Golden Drop with which it is almost identical. Bears heavily and is the finest of all Prunes. Its fruit, on account of its large size, is ranked as one of the most valuable Prunes and drying Plums.

\section{Quinces}

35 cents to 50 cents.

Champion. A vigorous and productive variety. Ripening very late.

CHAMPION QUINCE

Orange, or Apple. Large; roundish; bright golden-yellow, very productive. 


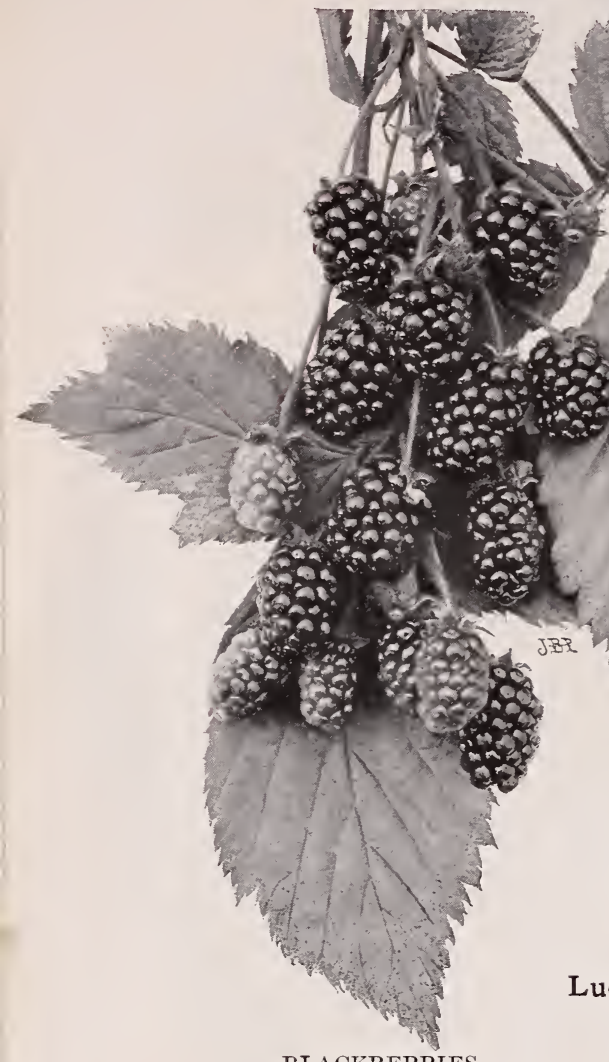

BLACKBERRIES (Reduced)

\section{SMALL FRUITS}

Low rates on all small fruits in quantities. Write for special prices on your list of wants.

\section{Blackberries}

Evergreen. Beautiful, cut-leaved foliage, which it retains during the winter; Berries large, black, sweet, rich and delicious; it continues to ripen from July to November, which makes it one of the best berries for family use; an excellent trellis and arbor plant. $15 \mathrm{cts}$. each; $\$ 1.00$ per dozen.

Kittatinny. Fruit large, roundish, conical, rich glossy black: firm, juicy, sweet and excellent; the variety, almost exclusively planted in this vicinity for market. 75 cts. per dozen.

New Mammoth. This wonderful new Blackberry, which was introduced as a novelty several years ago. has proved to be a grand addition to the list of Blackberries. The handsome, large, juicy berries are delicious. It is a rampant grower, of trailing habit; enormously productive, and exceedingly early, ripening three weeks before other cultivated kinds, thus bringing fancy prices. Fruit is enormous, specimens measuring $2 \mathrm{I} / 2$ in. long; seeds small, soft and abundant; cores small and soft.) In size and flavor it surpasses all other varieties of Blackberries. Small, well-rooted plants, 15 cts. each; $\$ 1.50$ per dozen.

\section{Dewberries}

Lucretia. A trailing variety of the blackberry, producing an abundance of large, glossy black, handsome fruit, of excellent quality; the fruit ripens early, and the plant does not sucker. $\$ 1.50$ per dozen.

\section{Currants}

Strong plants, $\$ 1.00$ per dozen; $\$ 6.00$ per 100 , except Perfection.

Black Naples. Very large; black; bunches of medium length. Much valued for jellies. Strong grower and coarse leaves.

Cherry. Fruit of the largest size; deep red, rather acid; short bunches; growth strong, stout, erect; short-joined shoots.

Fay's Prolific. This Currant has been widely planted and has given general satisfaction, and is the best red Currant known. Fruit very large, bright red and of excellent flavor; less acid than the Cherry. It has a long stem, which admits of rapid picking, and is enormously productive.

White Grape. Very large; yellowish-white; sweet, or a very mild acid; excellent quality and valuable for the table. The finest of the white sorts.

Perfection. W a s orig-

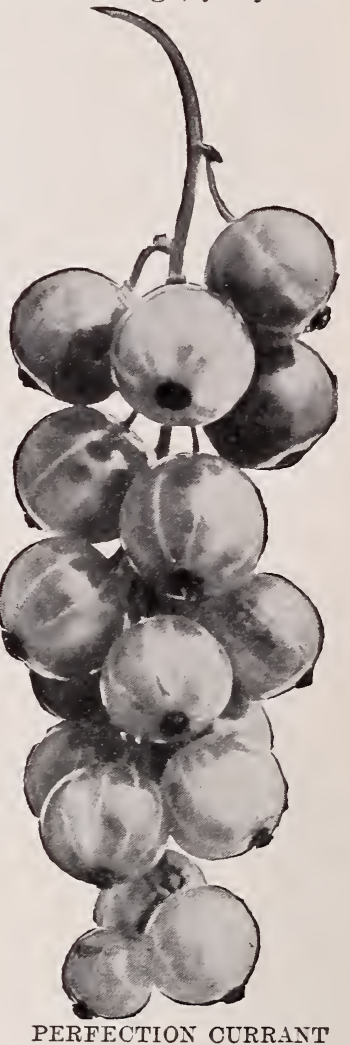

PERFECTION CURRANT

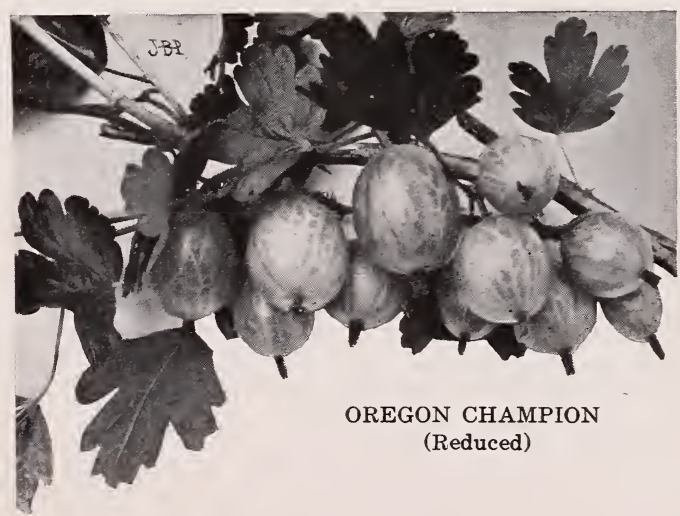
inated by Chas. G. Hooker of Rochester, N. Y., by crossing the Fay's Prolific with the White Grape Currant. Perfection was thoroughly tested at the N. Y. State Agricultura! Experiment Station at Geneva, N. Y., in competition with 60 varieties, and came out at the head on its general merits, as stated by Prof. S. A. Beach. Perfection also received in 1901, the highest award given any new fruit at the Pan-American Exposition. The color is a beautiful bright red. Size as large or larger than the Fay, the clusters averaging longer. The size of berry is well maintained to the end of the bunch. The Perfection has a long stem from point of attachment to the bush to the 
first berry, making it easy to pick without crushing any of the berries. Quality rich, mild, subacid, plenty of pulp with few seeds. Less acid and of better quality than any other large Currant in cultivation. It is very productive, vigorous grower with large healthy foliage. My plants are genuine, each one carries originator's label. Two year old plants, 25 cts. each; $\$ 2.50$ per dozen.

\section{Gooseberries}

Champion. An Oregon production. Fruit large, round and heavy bearer; entirely free from mildew. One of the best yet introduced for canning. 75 cts. to $\$ 1.00$ per dozen.

Industry. An English variety, more generally planted than any other, as it bears freely very large, dark red fruit of delicious quality. Very large. 25 cts. each; $\$ 2.50$ per dozen.

\section{Grapes}

15 cts. each; $\$ 1.50$ per dozen. Low prices in quantity.

Concord. This has been, for many years, the Grape for the million. Bunch and berries large; black, fair quality; vine very healthy, hardy and productive. The most extensively planted Grape in America.

Campbell's Early. Black. large bunches of good quality.

Delaware. Bunches small, compact, shouldered; berries rather small, round; skin thin, light red; flesh very juicy, without any hard pulp; very sweet, spicy and delicious flavor.

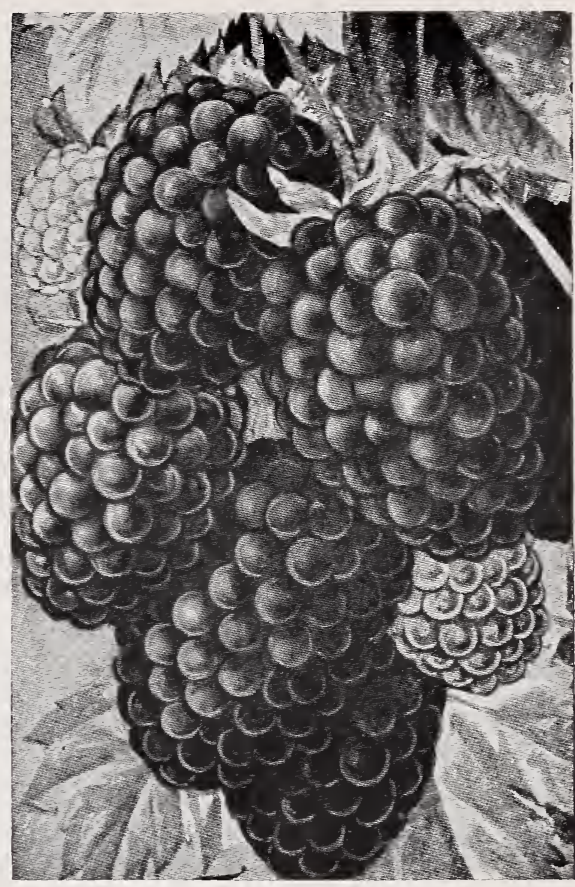

LOGANBERRY

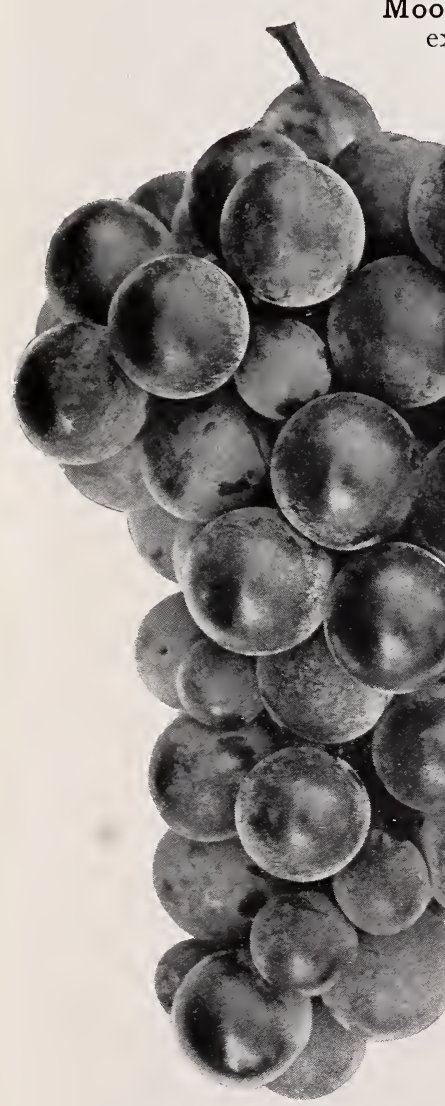

CONCORD GRAPES exceedingly hardy. Its earliness makes it desirable for an early market.

Niagara. Vine hardy; strong grower; bunches very large and compact, sometimes shouldererl; berries large, mostly round; light greenishwhite, semi-transparent; skin thick but tough, and does not crack; quality good; very little pulp, melting and sweet to the center.

Worden. A splendid, large Grape of the Concord type, but earlier, longer in bunch and berry, and of decidedly better quality; vine hardier than that old stand-by, and every way as healthy. A very popular sort, planted largely for market; next to Concord in number used. Really our best black Grape for home use.

Varieties such as Flame Tokay, Nalaga, Muscat and Rose of Peru can be supplied at low rates in quantity. These varieties are not successful in the Willamette Valley, but are adapted to the drier sections South and East.

\section{Loganberry, Blackberry-Raspberry}

Vine is an exceedingly strong grower; trails upon the ground like a-dewberry; fruit is often an inch and a quarter long, dark red, with the shape of a Blackberry; the color of a Raspberry, and the flavor a combination of both; a splendid shipper. Now widely known and deservedly popular. $\$ 1.00$ per dozen.

\section{Phenomenal Berry}

Originated by Luther Burbank; a cross between dewberry and red raspberry. Mr. Burbank describes it as exceeding all previous berries in size, bright color, and of great productiveness. The berries grow in clusters, each having five to ten or more, and individual berries often measure three inches around one way by four inches the other, and weigh one-quarter of an ounce each. A decided acquisition to our list of fruits.

$\$ 1.50$ per dozen. 


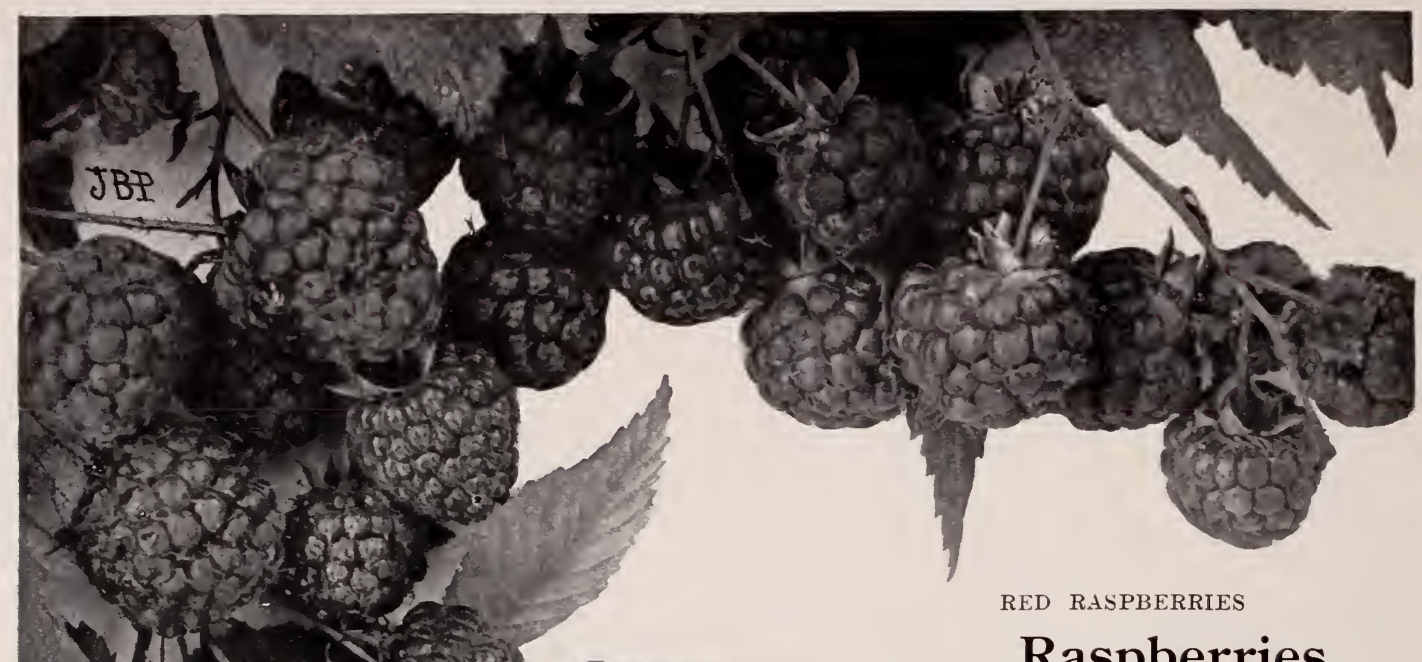

\section{Raspberries}

\section{Black}

Cumberland. Very large; very similar to Gregg in quality and firmness; in hardiness, and productiveness is unexcelled. One of the best midseason market varieties. 75 cts. per dozen.

Gregg. The leading late blackcap and a popular market sort. Canes of strong, vigorous growth and very productive; berries very large, covered with heavy bloom, firm, meaty and of fine flavor. It requires good, strong soil to produce best results and responds liberally to generous treatment. 75 cts. per dozen.

\section{Red}

Cuthbert, or Queen of the Market. A remarkably strong, hardy, red variety. The berries are very large, conical; rich crimson; flavor is sweet, rich and luscious. 75 cts. per dozen.

Marlboro. Fruit of the very largest size, of a bright scarlet color and of excellent flavor. A good shipper; canes very long and strong; foliage dark green; perfectly hardy; early. 75 cts. per dozen.

Superlative. A new red Raspberry, probably the largest and best berry grown. No longer an experiment, but a proven success for home and market planting. Fruit is immense and core small, making it solid and heavy. Canes are strong and erect. Well worthy of a thorough trial. Strong plants, $\$ 1.50$ per dozen.

\section{Yellow}

Golden Queen. A beautiful, large, golden-yellow berry, seedling of the Cuthbert, and surpassing that variety in size, beauty, quality and adaptability, succeeding in all sections. Canes hardy, of strongest growth, wonderfully productive. Should be in every home garden, its beauty and high quality placing it at the head for table use. 75 cts. per dozen.

\section{A Few Suggestions for Successful Culture.}

The preparation of the soil for raspberries should be thorough. The roots being close to the top of the ground and of a small, rather fibrous nature, the importance of having the soil in the very best possible condition to insure a good stand of plants and a satisfactory growth must be apparent to anyone engaging in the culture of berry plants. Thorough dressing with well rotted stable manure will do much to promote a vigorous growth the first season, and having secured this, profitable crops may be expected the second year after planting.

The first season all the shoots which have attained a height of two feet should be shortened in to twenty inches, this will cause them to send out many lateral shoots, so that instead of having the fruiting shoots confined to a few this will cause them to send out many lateral shoots, so that instead of having the fruiting shoots confined to a few canes, there will be a number of lateral shoots from each of the main canes for producing fruit clusters. These later-
als should have one-half of their growth cut off in the winter months. In the second year, as soon as the season's crop has been harvested, cut away the fruiting wood so that all the energy of the plant will be forced into the new growth. The young shoots should again be cut back at the proper height to develop laterals, and these, as has already been directed, should be cut back in the winter months. 


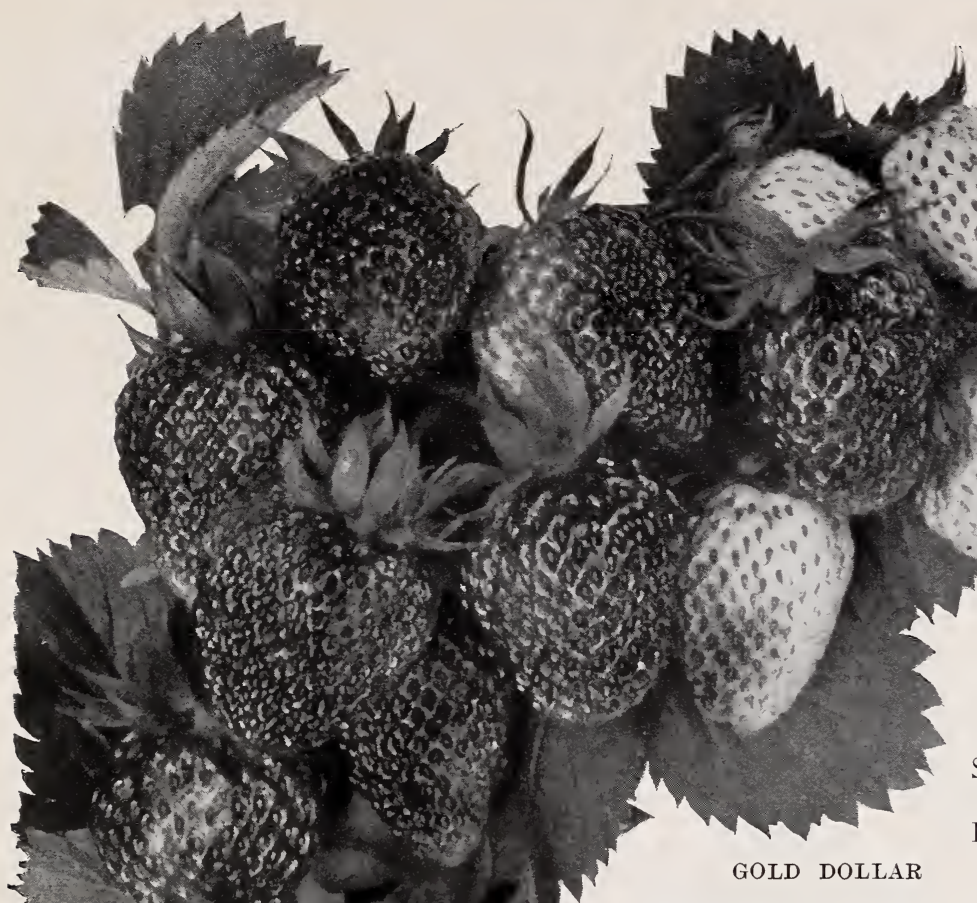

Gold Dollar. Earliest market berry, good medium size, and dark red all through; good flavor, rather tart, and fine for canning as well as table. A good bearer and money maker.

Hood River, or Clark's Seedling. Hood River Strawberries bring the highest price in the markets of the United States. A wonderful berry that stands shipment.

Magoon. Originated near Portland by Mr. Magoon. A fine, large, dark crimson berry. Vine strong, and one of the best for general purposes.

Marshall. One of the best all-round Strawberries; very large; dark crimson throughout; fine flavor; a fine market and table berry. One local grower says in size, appearance, flavor and sweetness it is superior to the popular Magoon.

Oregon. Comparatively new variety, possessing many good qualities; and, as it fruits from early to late, it makes a splendid berry for table purposes.

\section{Garden Roots}

\section{Asparagus}

For garden culture, plant in beds 2 feet apart each way. For field culture, make 5 feet apart and plant 2 feet apart in the rows. Set roots 6 to 8 inches below the surface, covering but 2 inches deep at first and filling in after plant has pushed forth, by degrees, the first season as you continue to cultivate. This plant needs no special care, other than a very liberal application of manure annually. The size and earliness are always proportionate to the amount of manure applied. Two-year-old plants, in leading varieties, $30 \mathrm{cts}$. per dozen; $\$ 1.50$ per 100 . Low prices in 1,000 lots.

\section{Horse Radish}

Every garden should have its Horse-radish. It flourishes in good soil. Roots, 25 cts. per dozen; $\$ 1.50$ per 100 . 


\section{Rhubarb or Pieplant}

This deserves to be ranked among the best early fruits in the garden. It affords the earliest material for pies and tarts, contintues long in use and is valuable for canning.

Plant in rows 4 feet apart and the plants 3 feet distant. Set the roots so that the crowns are about an inch below the surface. 2 -year-old roots, 75 c per doz.; $\$ 5.00$ per 100 .

\section{Nut Trees}

\section{Almonds}

The Almond is a success in the Willamette Valley, but to grow Almonds for commercial purposes, the higher and drier sections east of the Cascades, and the valleys of southern Oregon are preferable. However, no one with sufficient ground to spare should fail to plant one or more Almond trees. The following varieties are recommended.

4 to 6 feet trees, 35 cts. each; $\$ 3.50$ per dozen.

I. X. L. Tree a sturdy, upright grower, with large leaves; nuts large; shells easy, no bleaching necessary; soft shell, but perfect. It bears heavily and regularly. Highly recommended by orchardists who have tried it.

Ne Plus Ultra. A sturdy and rather upright grower; extremely prolific, producing its

nuts in bunches all over the twigs; nuts large and long; almost invariably of one kernel; of fine flavor; hulls readily.

Nonpareil. Of a sweeping style of growth, but still forms a beautiful tree; an extraordinarily heavy and regular bearer, with very thin shell.

\section{Chestnuts}

Thousands of acres on the Pacific Coast are admirably adapted to Chestnuts. As a shade or avenue tree, they are highly ormamental, and the crop gives satisfactory returns.

American $\mathrm{S}$ we e t. The fruit of this variety is a great deal smaller than that of European kinds, though the kernel is very sweet-the sweetest of all-and well flavored. 35 cts.

Italian, or Spanish. troduced from Europe. Strong grower and very productive, a $\mathrm{nd}$ valuable both for ornament and fruit. Not much larger than the American Sweet. 25 to $35 \mathrm{cts}$.

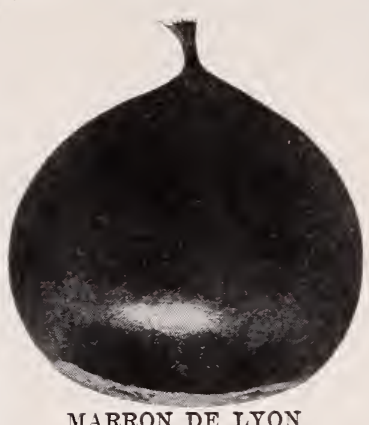

MARRON DE LYON ently dwarfish. Grafted trees, 35 to 50 cts.

\section{French Chestnuts}

Marron de Lyon. One of the largest and best recommended kinds for market; exported from France to all countries as a dessert nut. Nut quite large, round and of first quality. Wood and leaves much like those of Combale. Grafted trees, $\$ 1.00$ to $\$ 1.50$. See illustration.

Marron Nouzillard. The kind mostly raised in the northwest of France. Very productive and precocious. The nut is of fair size, of a light brown, and generally two or three in a burr. The wood of the Nouzillard is of a reddish-brown, the buds having much of a shoulder; the leaves are wide and glossy. Grafted trees, $\$ 1.00$ to $\$ 2.00$. See illustration.

Japanese. Grafted trees of this variety often produce nuts the first season. They are of fair size and good quality. Tree is appar-

\section{Filberts}

The only nut that is a native of the north Pacific Coast is the Filbert, or common Hazel. It is a singular fact, in view of the success that is being attained in growing Almonds, Chestnuts, Filberts and Walnuts, that virtually we have no other indigenous nut trees. Filbert should be trained as a tree and not as a shrub, and all sprouts should be removed. 4 to 6 feet, $35 \mathrm{cts}$; 3 to 4 feet, 25 cts. Low prices in quantity.

Barlecona. A magnificent variety from Spain; nut very large, round, of first quality. Very productive. Bears well, trained both ways, either as a low standard tree, or bush.

Du Chilly. The largest Filbert ever fruited on the Pacific Coast. The nut is of an elongated oval, very broad, over an inch in length, and three-fourths of an inch in width. The nuts are uniformly large, full-fleshed and sweet. Trained as a low standard tree, this cobnut is immensely prolific, but a shy bearer if raised as a bush.

\section{Hickory. Carya}

Shell-bark Hickory. This very striking and profitable woodproducing tree of the Eastern and Middle States, has never been extensively planted in Oregon, there being very few localities where the climatic conditions are favorable for its

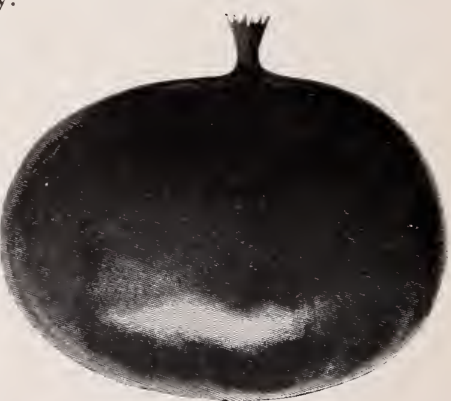

MARRON NOUZILLARD perfect development. Deep, well-drained, fertile loams, either of sandy or clayey nature, are the most acceptable for the rapid development of the tree, with a humid, moderately warm climate in the summer months. The nuts have a peculiar rich, nutty flavor, equaled by no other variety. 35 to $50 \mathrm{cts}$. 


\section{Walnut}

Walnuts are now being planted in the Pacific Northwest by hundreds of acres. The impetus is deserved. It has been proven that here we can grow Walnuts superior in flavor to all other sections, without exception. This applies to the hardy, late-blooming French varieties, - nuts which have always commanded the highest prices in the markets of the world.

No nut yields larger and more profitable returns than the Walnut; the tree is practically free from all insect pests, and when once established, requires little care, so far as pruning and spraying are concerned.

For size and beauty of the nuts, no variety can surpass the Mayette and Franquette. But size and beauty of the nuts are not the only advantages of these kinds over others, for they are, besides, hardy, budding out late, and never injured by frost in the spring or in the fall on our place. As to their fertility, bearing trees of these kinds, grafted and second-generation seedling trees, though rather young, yet bear heavily, and they have turned out to be very productive wherever given a good trial, in Oregon and Washington, as well as in California. In a climate like that of the Pacific Coast, the first requisite as to the best market Walnut to plant, is first, hardiness; second, size and beauty of nut; third, fertility; and our honest opinion is that the varieties above named, combine, each of them in themselves, these three important requisites.

My stock of second generation trees is imported from France, where they are grown one year by one of the most reliable French growers.

This year I am offering grafted trees, having secured scions from bearing trees-trees that are annual bearers of large, fine nuts. Grafted trees commence to bear earlier than seedling trees, and the product is more uniform in size; but their ex-

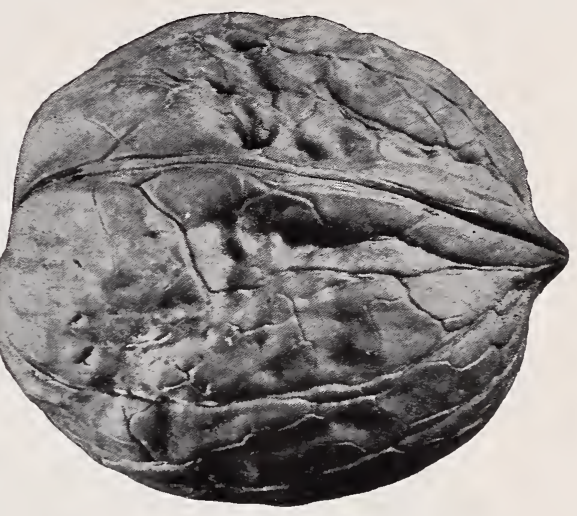

MAYETTE WALNUT pense and scarcity discriminate against them, especially in extensive plantings

Grafted trees, 4 to 6 feet, $\$ 1.50$ each; second generation seedlings: One year stock, $\$ 20.00$ per hundred; 2 to 4 year old transplanted trees, from 35 to $75 \mathrm{cts}$. each.

Mayette. This is one of the finest dessert and market nuts grown; it is quite large and even in size, well shaped, with a light colored shell; the kernel is full fleshed, sweet and nutty. But what renders this valuable kind more valuable yet is its hardiness, being late in budding out, which enables it to escape uninjured the disastrous effects of late frosts in the spring: it is also an abundant bearer. This is the nut imported

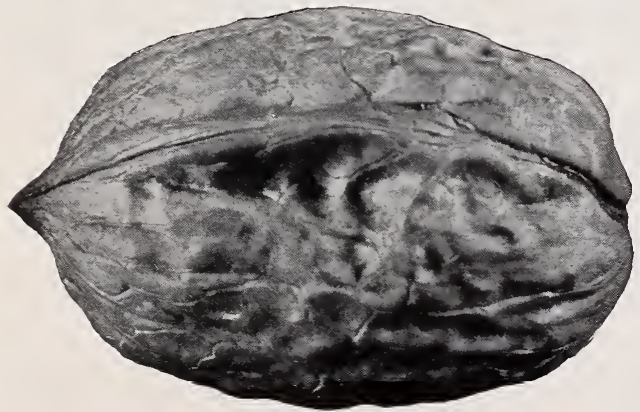

FRANQUETTE WALNUT

in the United States under the name of Grenoble, but on account of duties to pay, and the nut being a high priced one in its home, in France, a common and cheaper grade is often mixed with it, to the disgust of nut importers in New York and Chicago. The Mayette was originated in the southeast of France by a man of the name of Mayette, 135 years ago, the nut having ever since been a great favorite as a market nut. See illustration.

Franquette. Originated about the same time as the Mayette in the southeast of France by a man named Franquet. The nut is quite large, of an elongated oval, and very attractive, kernel full fleshed, sweet and rich. It also buds out late in the spring, being as hardy as Mayette and Parisienne. Very desirable as a market Walnut. See illustration. The two preceding named are the representative varieties.

Chaberte. An old and most esteemed variety; late in budding out. The nut is well shaped, roundish oval, and of medium size; the kernel is of extra fine quality; good bearer. The Chaberte was originated over a century ago by a man named Chabert, in France, hence its name. Very rich in oil.

Parisienne. This nut, also one of the finest for dessert and market, was originated in the southeast of France, and not in the neighborhood of Paris, as its name would imply; its beauty caused it to be called Parisienne in honor of the capital of France. The nut is large, broader at the small end than the Nayette and Franquette and has a very pretty shape.

\section{Walnut-American}

American Black. A very large, spreading tree, with pinnate foliage. Well known and valuable, both for its nuts and timber, furnishing the well-known Walnut lumber of commerce. 50 to 75 cts.

\section{Butternut-White Walnut}

A beautiful growing tree, wide spreading head, reddish dark foliage, very hardy. Nuts large, rough, hard shells, with sweet, rich white kernels, oily but delicate flavor. 50 to $75 \mathrm{cts}$. 


\section{Dwarf Fruit Trees}

Dwarf fruit trees have been used in Europe for generations and in Japan for centuries, but up to the last few years comparatively little attention has been given them in the United States, tho their use is constantly growing and will increase even more rapidly as their adaptability becomes known.

Dwarf trees do not attain the size of standard stock, therefore adapt themselves to the environments of the suburban grower whose space is limited, and on account of the size of these trees enables the grower to have more of them, consequently greater variety, than the commercial planter whose land is less valuable.

The trees are easily taken care of as their growth can be kept within reach, and pruning, spraying and picking can be done from the ground without resorting to ladders, as would be necessary with standard grown trees.

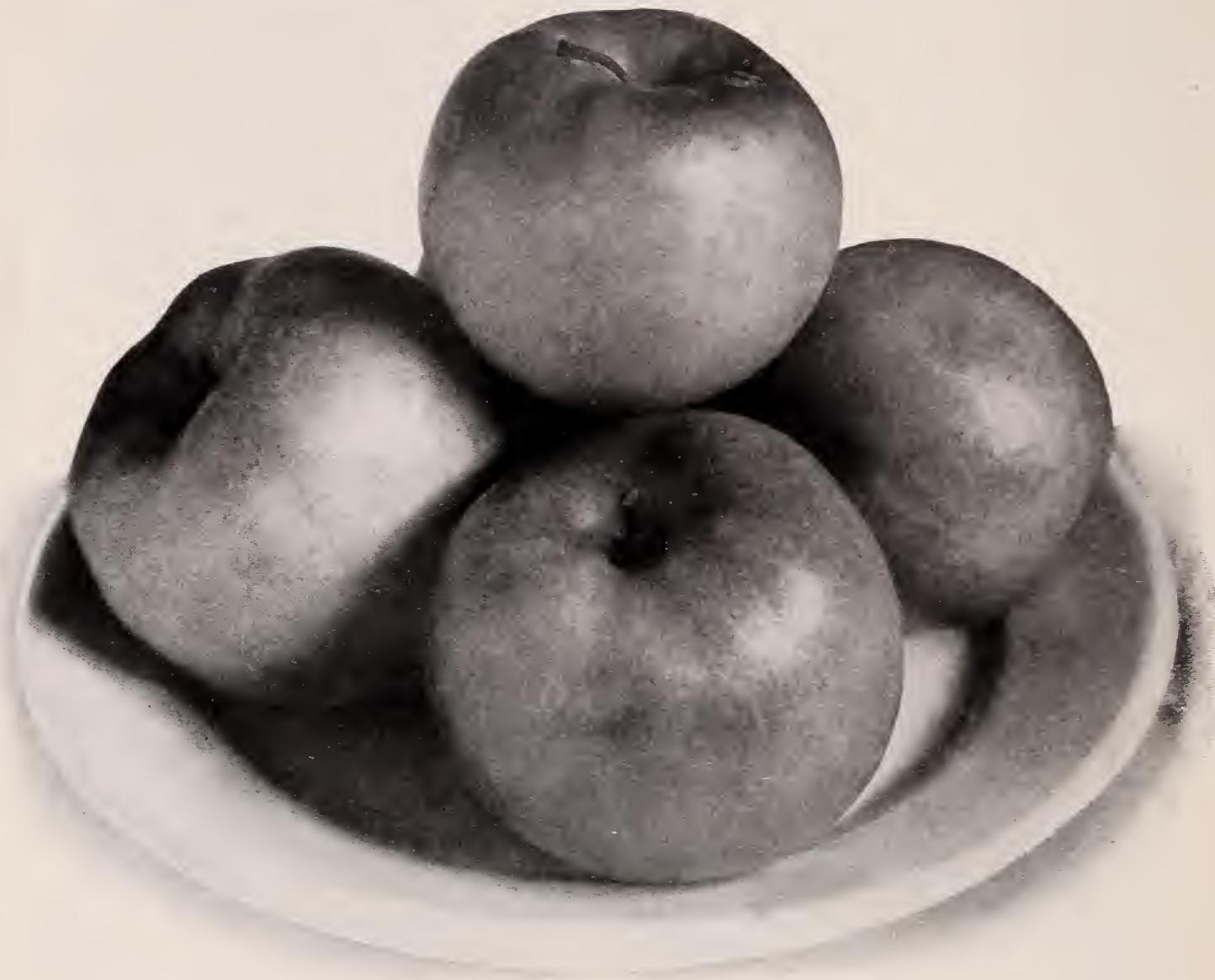

IELLOW TRANSPARENT

I am now able to supply. Dwarf Apple and Pear trees in varieties well known to the Coast section and would advise planting of these by all who want quick results, and where space is an object.

\section{Dwarf Apples}

Selected one year trees, 50 cts. each

Yellow Transparent. Very early hardy Russian variety. Large; pale waxen, transparent yellow. Quality best of early apples, subacid, crisp and fragrant.

Red Astrachan. Beautiful apple, yellow; largely covered with light and dark red. Medium size, quality good.
Sweet Bough. Large pale yellow apple, tender, sweet and very good for all purposes.

Red June. Attractive little apple, nearly covered with brilliant red. Subacid, tender and very juicy.

Tetofsky. Medium size, with yellow ground handsomely striped with red and covered 
with a whitish bloom; flesh juicy, sprightly, acid and agreeable. Tree good grower, vigorous and hardy, and very productive.

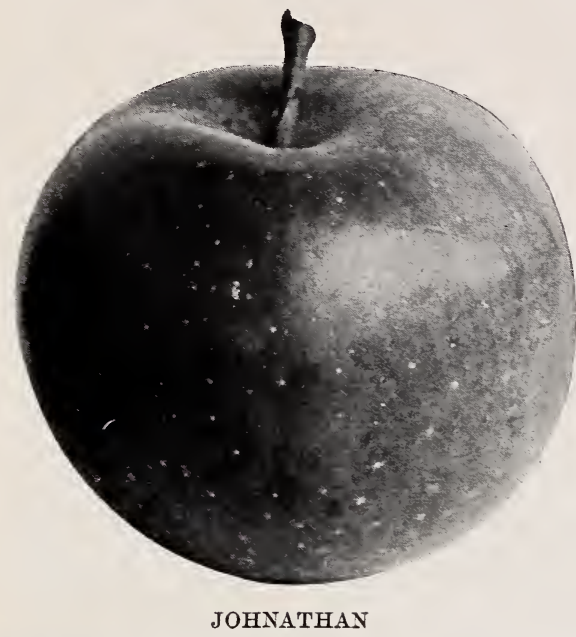

Gravenstein. Large, handsome, deep yellow streaked and splashed with deep red. Qual- ity very best, fruit tender, crisp, pleasantly acid. Tree vigorous, constant and heavy bearer.

Ortley. A coming Hood River favorite. Pale yellow, of the Belleflower type but less acid and a better dessert and all purpose apple.

Delicious. Brilliant dark red, with yellow; large size and excellent quality. A market favorite.

Winter Banana. Large, clear pale yellow with delicate pink blush, very attractive. Brings highest price of any variety as a dessert apple.

Johnathan. Beautiful red apple, highly flavored and excellent quality, tender, juicy, spicy and rich. One of the very best for all purposes.

Spitzenberg. Medium large, covered with dark red or faint-striped with darker red and pale yellow; firm, crisp, subacid and aromatic. A good keeper.

Yellow Newtown. Bright yellow with pink blush, richly flavored, firm, crisp, juicy, good quality and one of the very best keepers. The most famous Hood River variety, very profitable.

\section{Dwarf Pears}

Selected one year trees, 50 cts. each.

A few fine two year old trees, 75 cts. each.

Anjou. One of the best; late fall pear; large, handsome greenish-yellow with dull red and russet; tender, juicy and most excellent quality.

Bartlett.. Rich golden-yellow, often with pinkish-red blush. Highest quality, thin skinned, buttery and melting, very rich flavor. One of the best for eating and for canning.

Seckel. Very small, yellowish-brown pear of highest quality, tender, spicy and melting.
Bosc. Handsome deep yellow, slightly russet, highest quality, tender and aromatic.

Comice. Yellow, faintly blushed crimson, fine quality, good keeper.

Winter Nelis. Small yellowish-green russet pear, not handsome, but most delicious when properly ripened. Should be picked just before frosts, and packed away in dark cellar until ripe. Flesh fine grained, melting, buttery and very spicy.

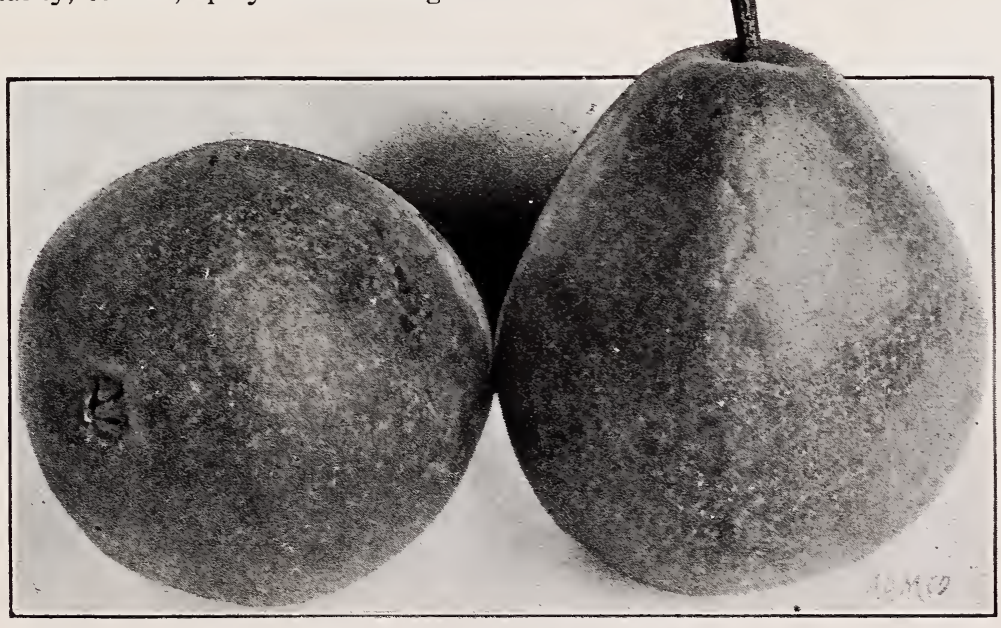

WINTER NELIS PEARS (Reduced) 


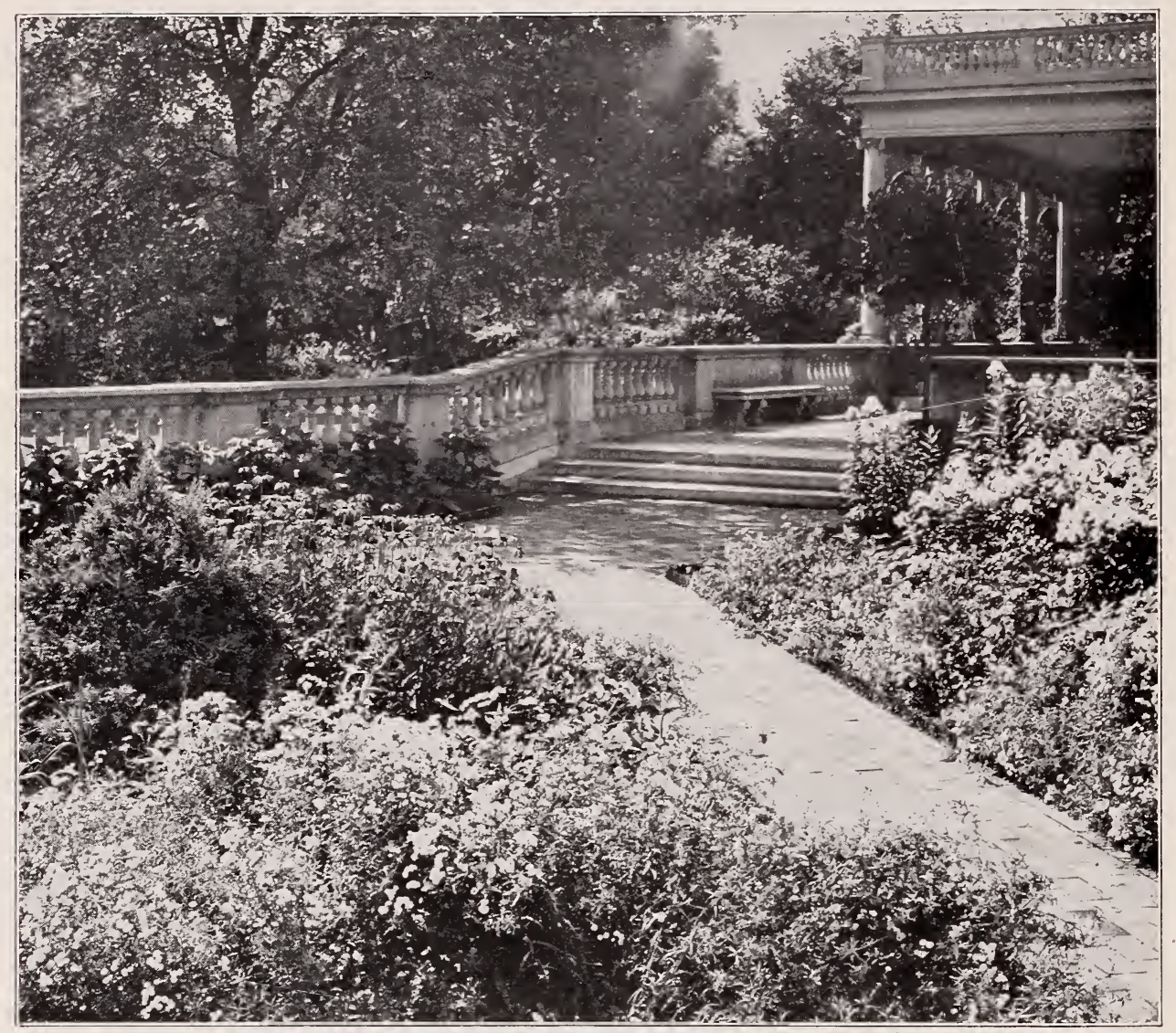

A FINE HERBACEOUS GARDEN 


\section{INDEX}

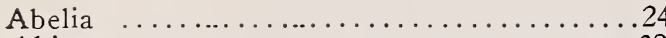

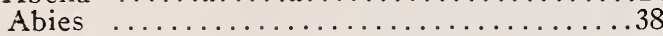

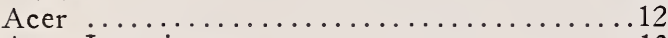

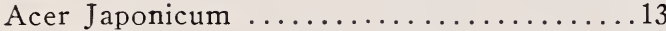

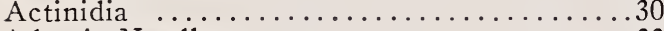

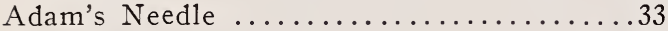

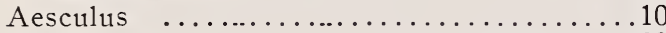

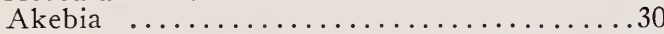

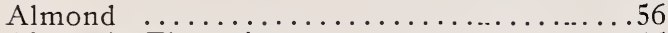

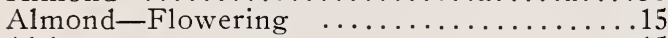

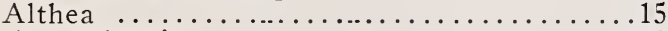

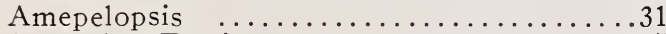

Amorpha, Fruticasa ....................

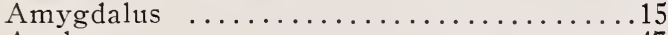

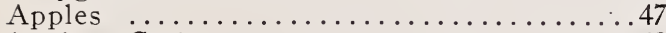

Apples, Crab ...................... 48

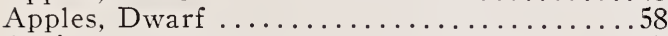

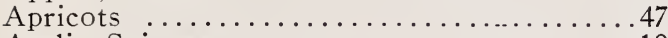

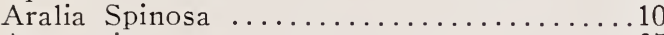

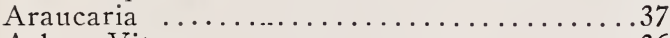

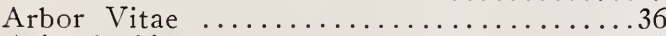

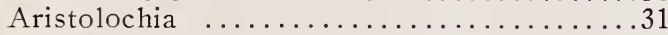

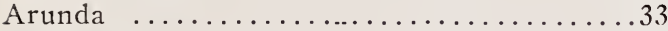

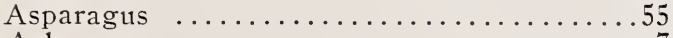

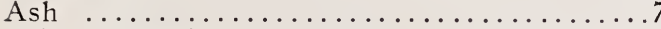

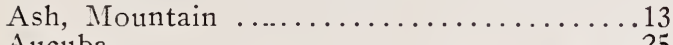

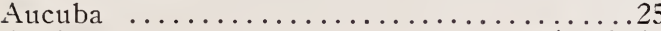

Azaleas ...................15, 16, 25

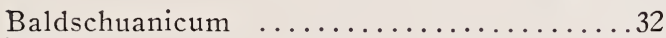

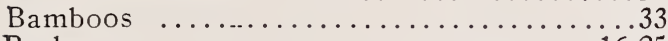

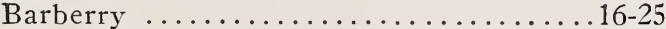

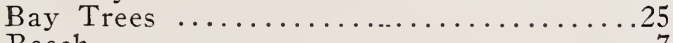

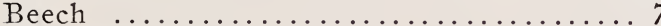

Berberries ....................... 16-25

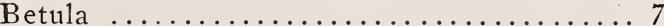

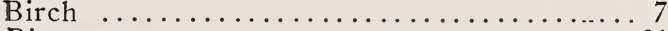

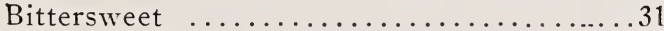

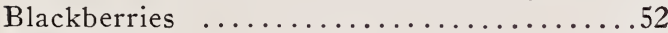

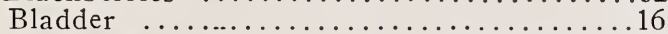

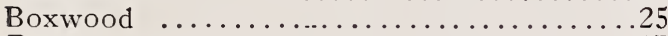

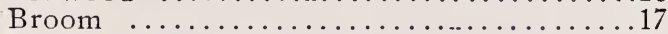

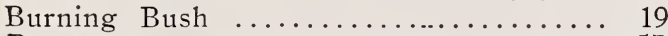

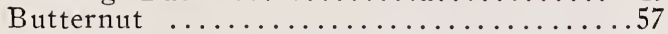

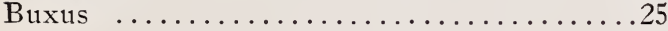

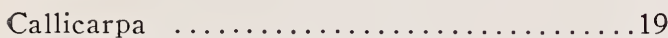

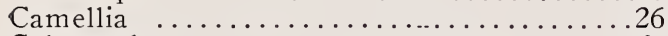

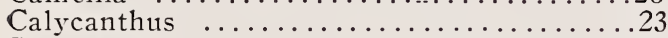

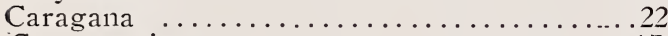

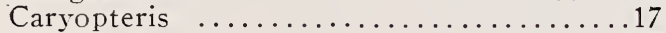

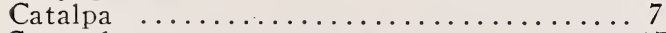

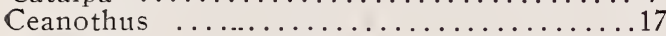

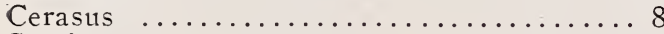

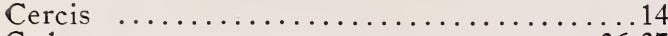

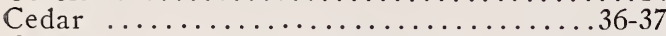

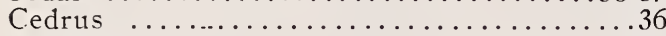

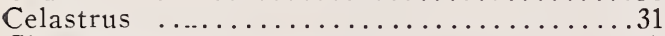

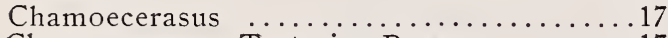

Chamoecerasus, Tartarica Rosea ............17

Cherries ....................... 47

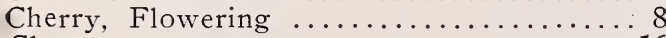

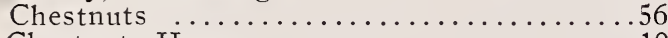

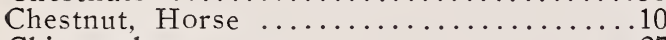

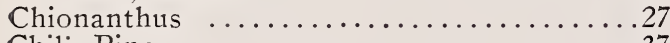

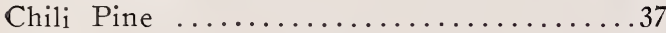

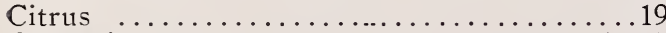

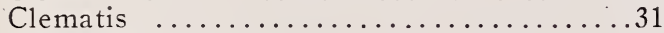

Conditions $\ldots \ldots \ldots \ldots \ldots \ldots \ldots \ldots \ldots \ldots \ldots \ldots \ldots$

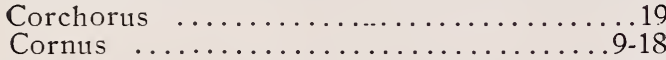

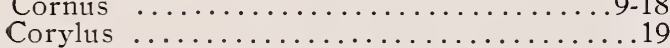

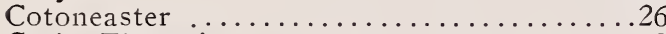

Crab, Flowering ................... 8

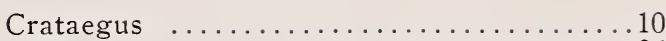

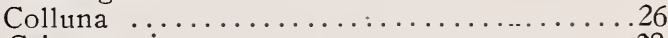

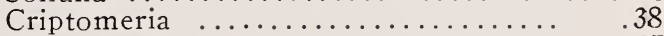

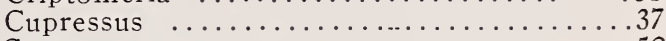

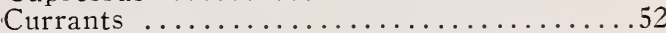

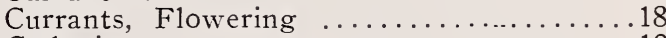

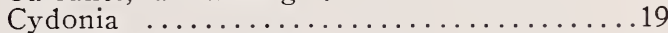

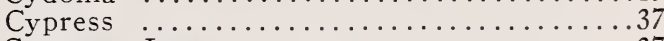

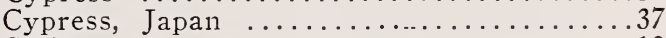

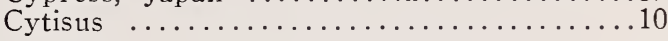

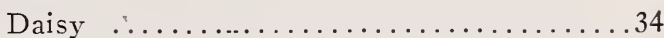

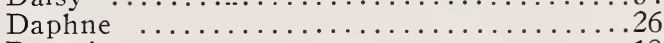

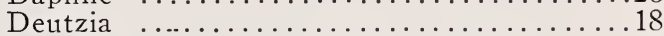

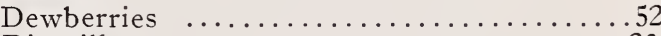

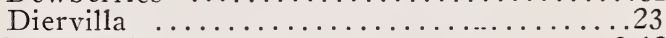

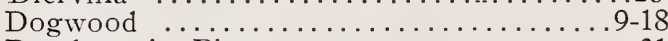

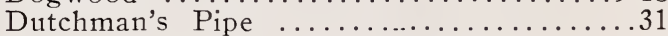

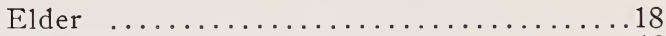

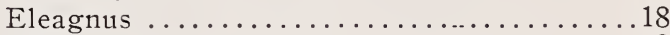

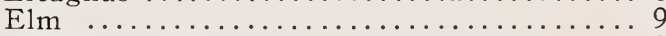

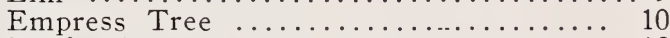

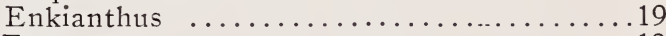

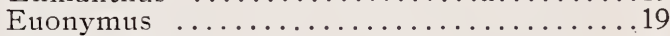

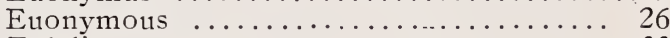

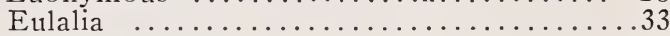

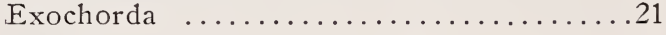

Fagus $\ldots \ldots \ldots \ldots \ldots \ldots \ldots \ldots \ldots \ldots$

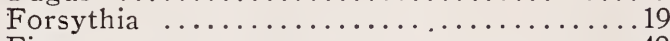

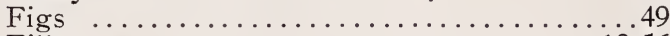

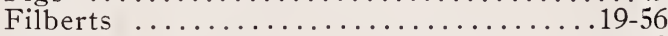

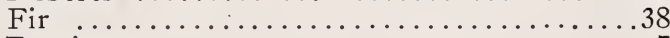

Fraxinus Fringe, White $\ldots \ldots \ldots \ldots \ldots \ldots \ldots \ldots \ldots \ldots \ldots \ldots \ldots \ldots \ldots \ldots \ldots \ldots \ldots^{7}$

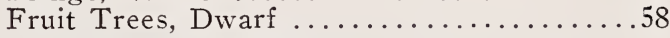

Gardening, Landscape ............... 5

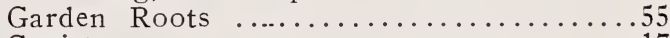

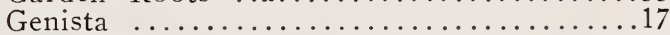

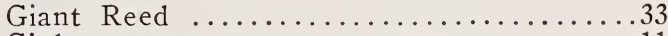

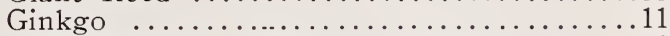

Gleditsia, Triacanthos ................

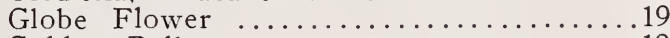

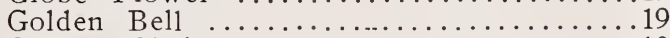

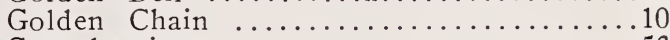

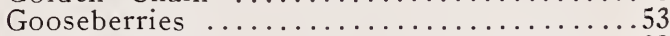

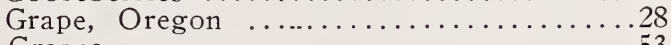

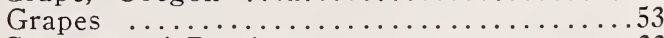

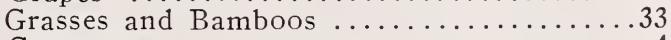

Guarantee
Gynerium $\ldots \ldots \ldots \ldots \ldots \ldots \ldots \ldots \ldots \ldots \ldots \ldots \ldots \ldots \ldots \ldots \ldots \ldots$

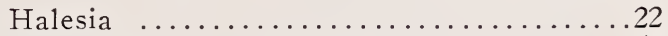

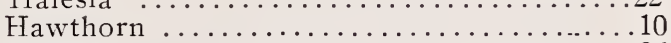

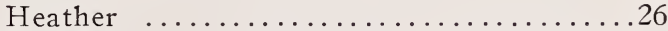

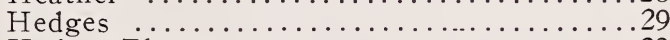

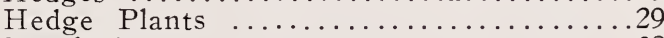

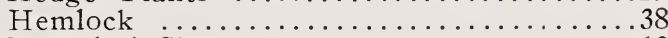

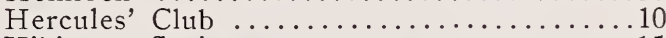

Hibiscus, Syriacus ...................... 15

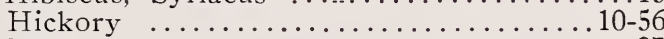

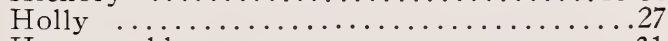

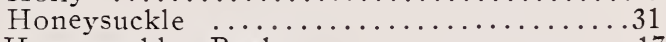

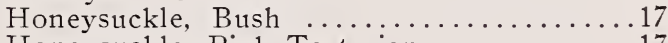

Honeysuckle. Pink Tartarian .......... 17

Horse Radish ................... 55

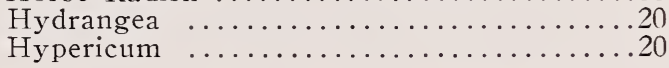

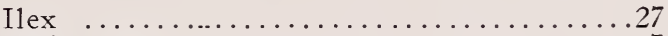

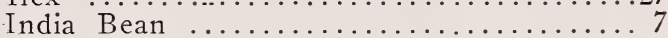

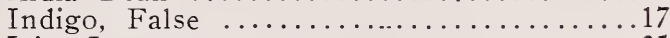

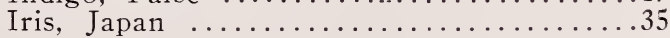


Iris, Kaempferi ................... 35

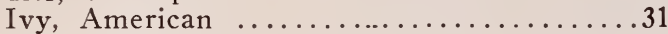

Ivy, English $\ldots \ldots \ldots \ldots \ldots \ldots \ldots \ldots \ldots \ldots \ldots$

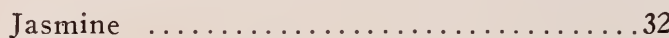

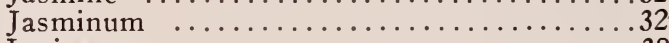

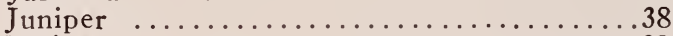

Juniperus $\ldots \ldots \ldots \ldots \ldots \ldots \ldots \ldots \ldots \ldots \ldots \ldots \ldots \ldots$

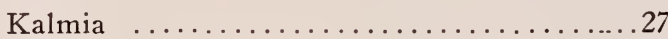

Kerria ........................... 19

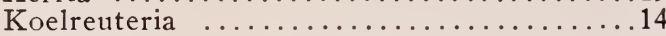

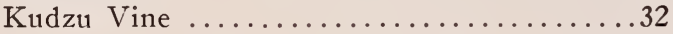

Laburnum $\ldots \ldots \ldots \ldots \ldots \ldots \ldots \ldots \ldots \ldots \ldots$

Landscape Gardening..$\ldots \ldots \ldots \ldots \ldots \ldots 5$

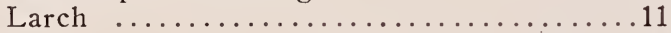

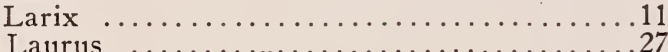

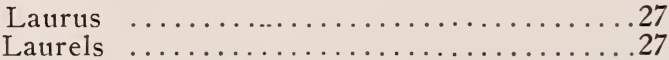

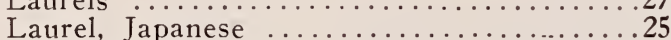

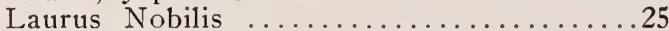

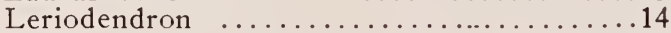

Lilacs .........................21

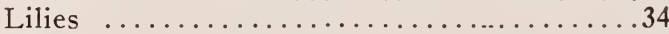

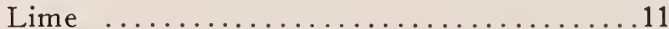

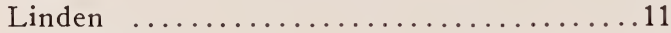

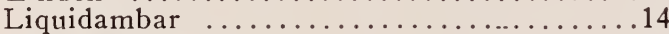

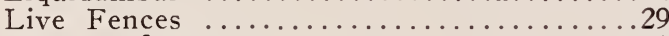

Locust, Honey ........................ 10

Loganberry $\ldots \ldots \ldots \ldots \ldots \ldots \ldots \ldots \ldots \ldots \ldots \ldots \ldots \ldots \ldots \ldots \ldots \ldots \ldots$
Lonicera $\ldots \ldots \ldots \ldots \ldots \ldots \ldots$

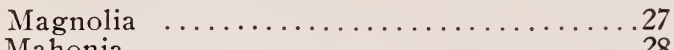

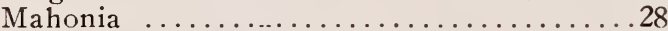

Maidenhair Tree . . . . . . . . . . . . . 11

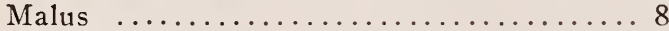

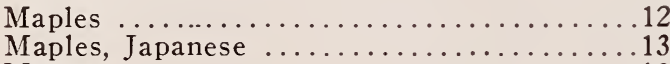

Morus $\ldots \ldots \ldots \ldots \ldots \ldots \ldots \ldots \ldots \ldots \ldots \ldots \ldots \ldots \ldots \ldots \ldots \ldots \ldots \ldots \ldots \ldots \ldots \ldots \ldots \ldots$
Mulberry $\ldots \ldots \ldots \ldots \ldots \ldots \ldots$

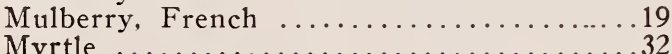

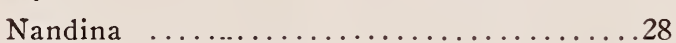

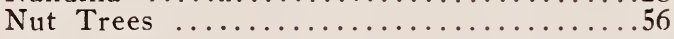

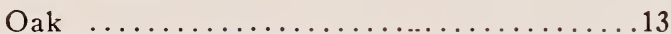

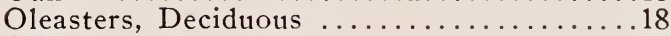

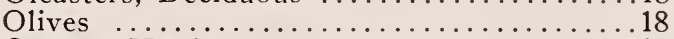

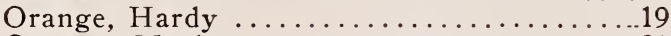

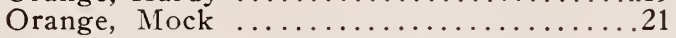

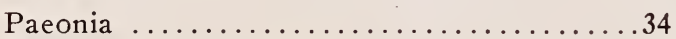

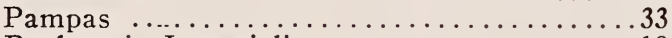

Paulownia Imperialis $\ldots \ldots \ldots \ldots \ldots \ldots \ldots \ldots$

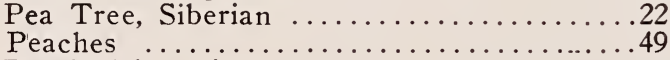

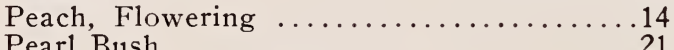

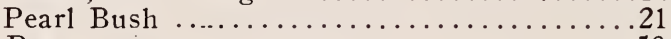

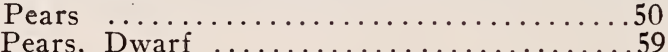

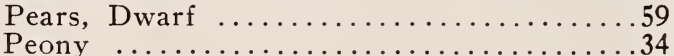

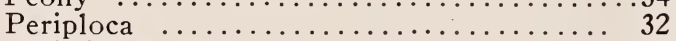

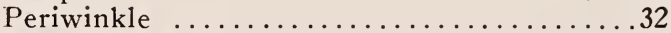

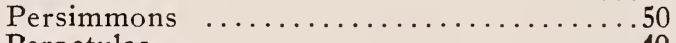

Perpetulas ........................40

Phenomenal Berry $\ldots \ldots \ldots \ldots \ldots \ldots \ldots \ldots 53$

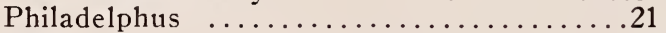

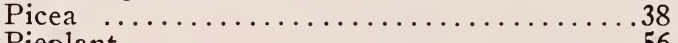

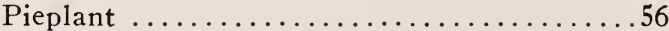

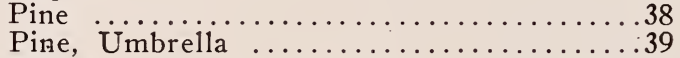

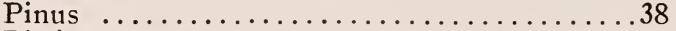

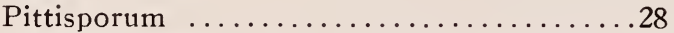

Planting Season .................... 4

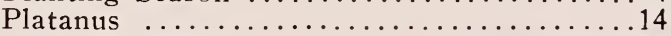

Plum, Flowering ................... 14

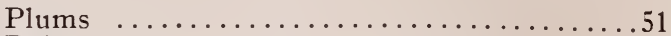

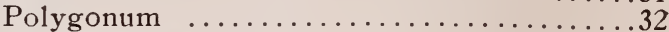

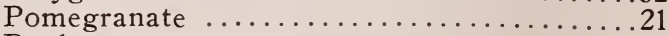

Poplar ..........................

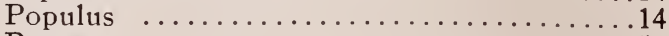

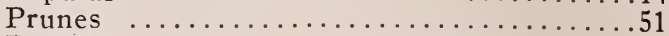

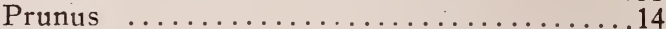

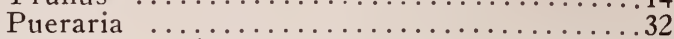

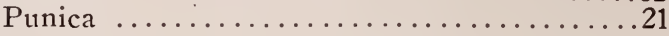

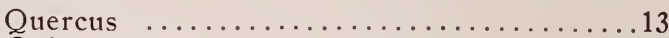

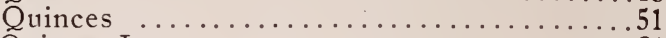

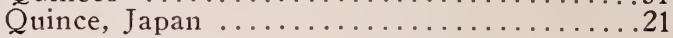

Raspberries, .................. 54

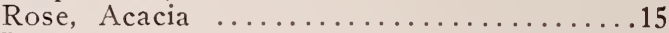

Roses ..................40, 45

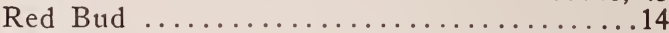

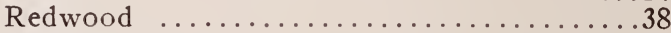

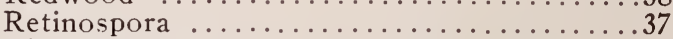

Rhododendrons .................28

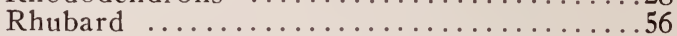

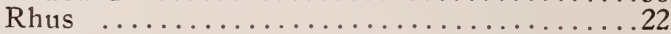

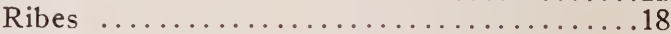

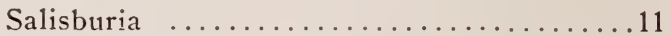

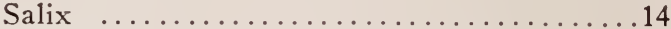

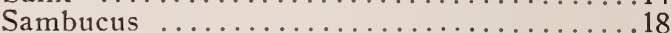

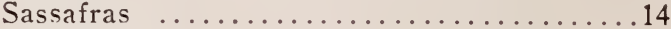

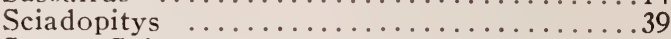

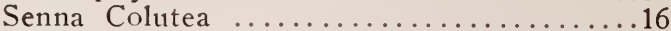

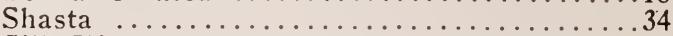

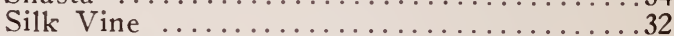

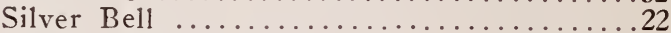

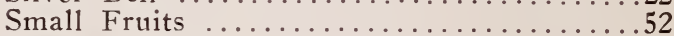

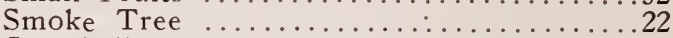

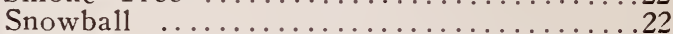

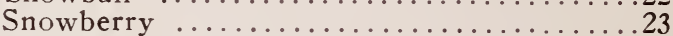

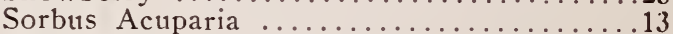

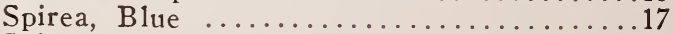

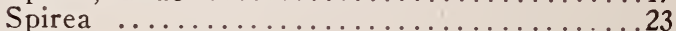

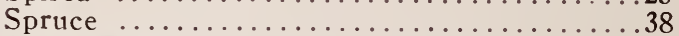

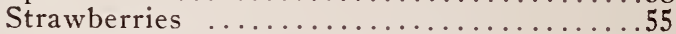

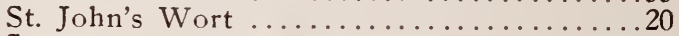

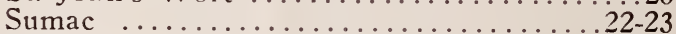

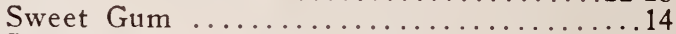

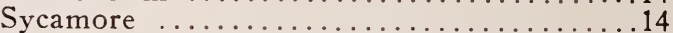

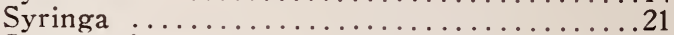

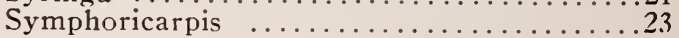

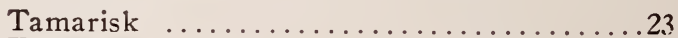

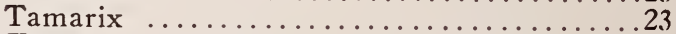

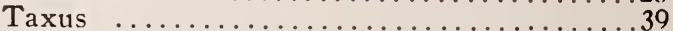

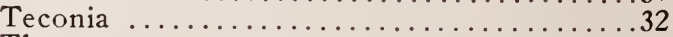

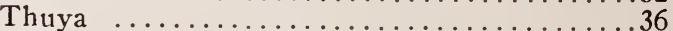

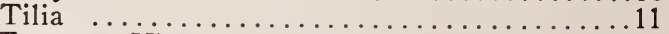

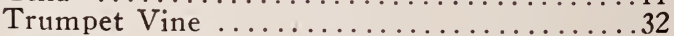

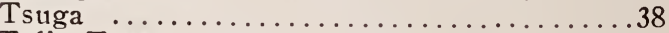

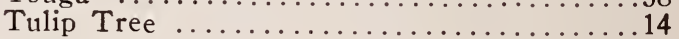

Ulmus ...................... 9

Umbrella Pine .......................

Varnish Tree ..................... 14

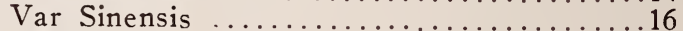

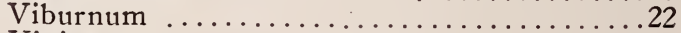

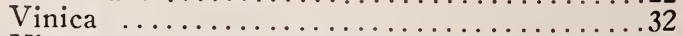

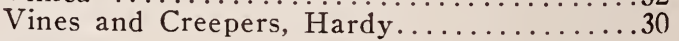

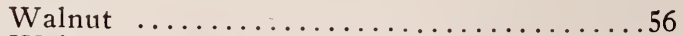

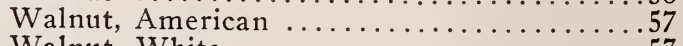

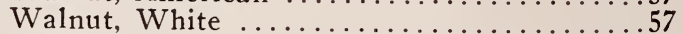

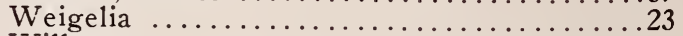

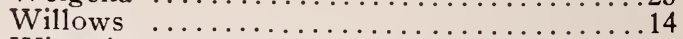

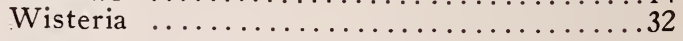

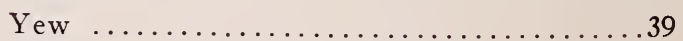

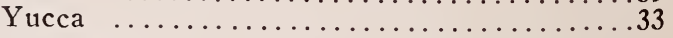




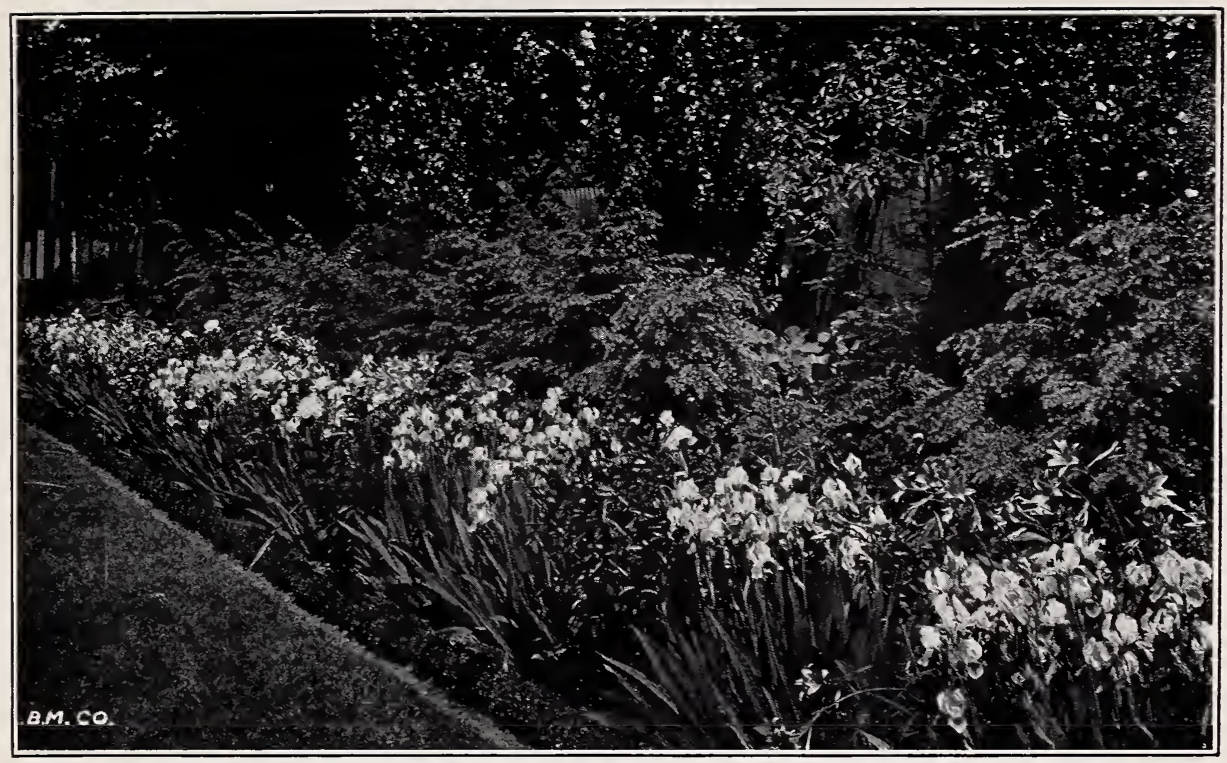

GERMAN IRIS, IN BORDER

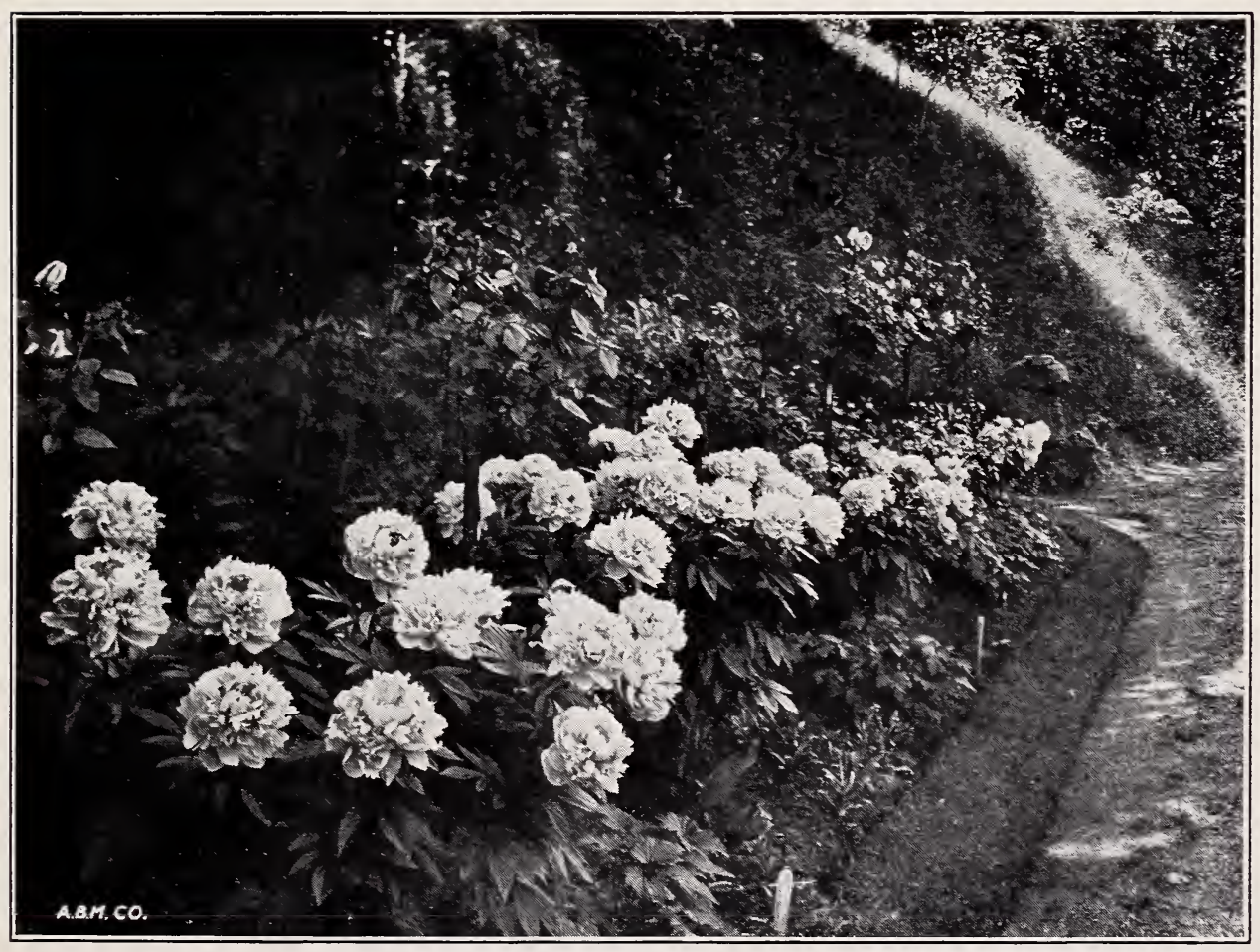

PAEONIES, IN BORDER 
